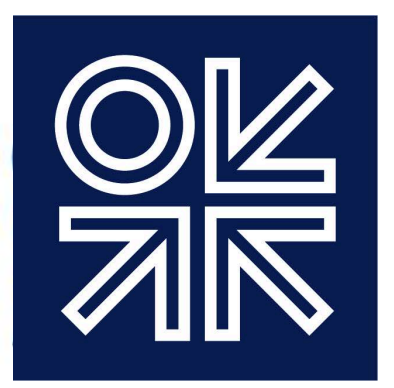

THE OXFORD

INSTITUTE

FOR ENERGY

STUDIES

July 2017

\title{
The Outlook for Floating Storage and Regasification Units (FSRUs)
}

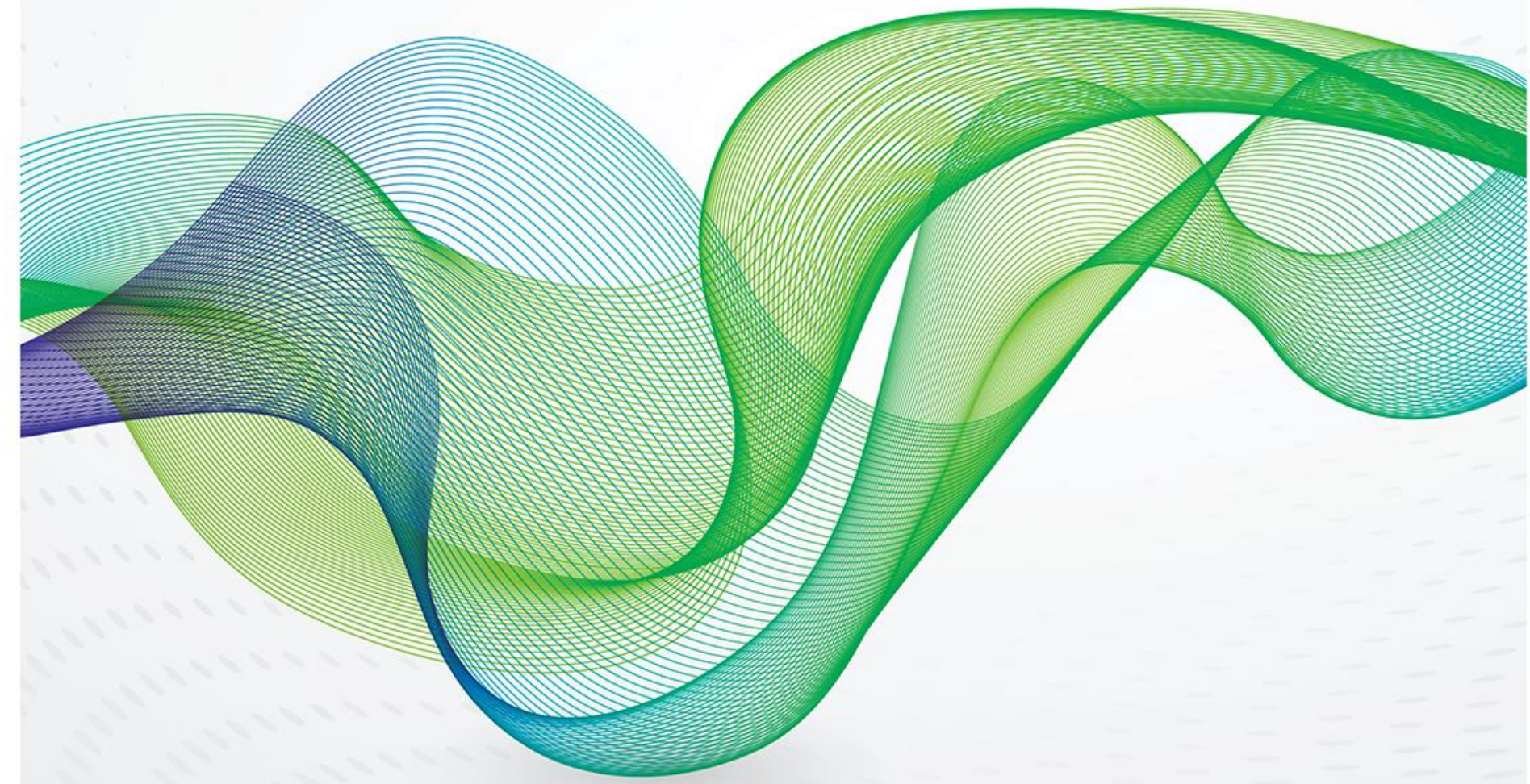



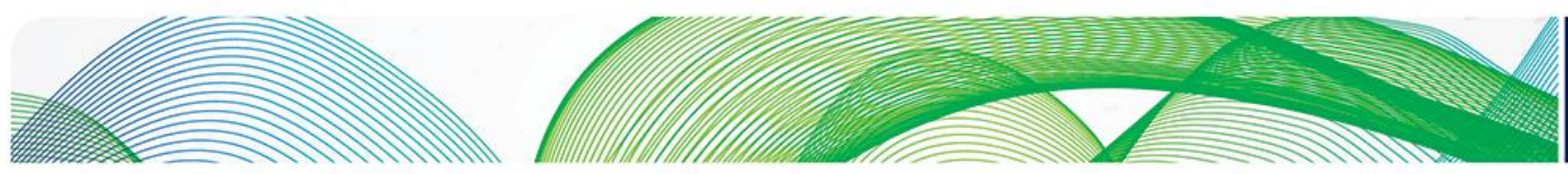

\section{O는}

The contents of this paper are the authors' sole responsibility. They do not necessarily represent the views of the Oxford Institute for Energy Studies or any of its members.

Copyright $\odot 2017$

Oxford Institute for Energy Studies

(Registered Charity, No. 286084)

This publication may be reproduced in part for educational or non-profit purposes without special permission from the copyright holder, provided acknowledgment of the source is made. No use of this publication may be made for resale or for any other commercial purpose whatsoever without prior permission in writing from the Oxford Institute for Energy Studies.

ISBN 978-1-78467-089-4 

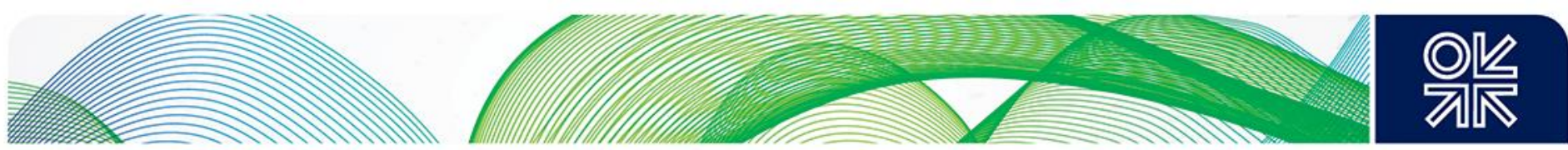

\section{Acknowledgements}

My thanks to colleagues in the LNG industry for their input and final review.

Paper updated $31^{\text {st }}$ January 2018. 

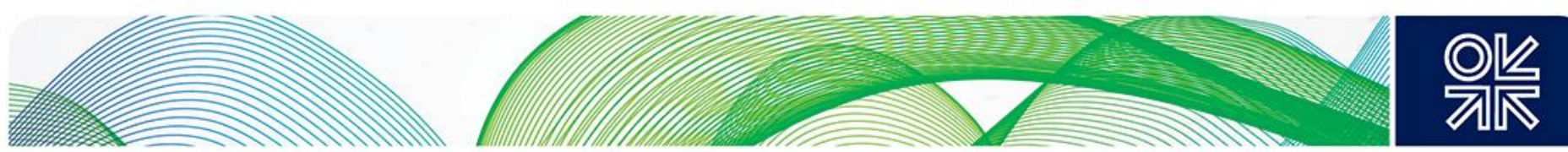

\section{Preface}

As the future of gas in the decarbonizing global energy economy is established, the opening of new, and likely small, markets will be crucial. Many of these new markets will not have access to existing gas infrastructure and will not possess the desire or the confidence in future demand levels to construct significant onshore facilities to receive LNG and regasify it. As a result, for those countries with access to the sea, the availability of flexible, floating storage and regasification units will be vital to reduce the early risks of gas market development. Indeed, these FSRUs can even catalyse the movement towards gas-to-power projects that are becoming increasingly popular today.

With his traditional thoroughness, in this working paper Brian Songhurst outlines the development of the relatively new FSRU business over the past 16 years. He describes the physical processes involved, the capital and operating cost parameters and the key benefits of using an FSRU vessel. He also details the main players in the industry and the contractual models which they have developed over the past decade and a half. Finally, there is also a full listing of all the current vessels in operation, as well as those under construction, to provide the reader with a comprehensive overview of the state of the market as it currently stands in mid-2017.

Given increasing customer requests for more flexible, and shorter term, gas purchase contracts, and the increasing uncertainties surrounding the future of gas demand in a world where renewables and coal continue to provide stiff competition, it is clear that the gas industry will need to be innovative if it is to prosper. The development of FSRUs is an example of one such innovation, and we believe that this working paper can provide an excellent introduction and analysis of this emerging industry.

James Henderson

Oxford July 2017 

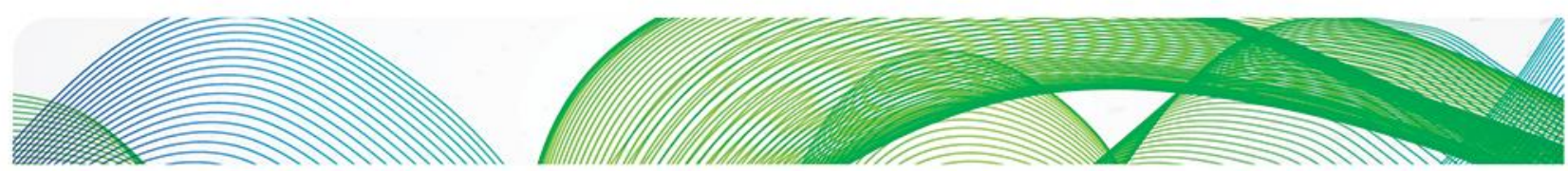
O倸

\section{Contents}

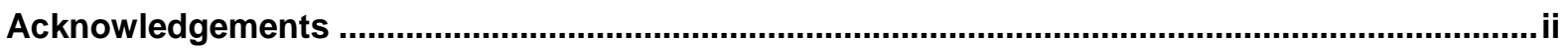

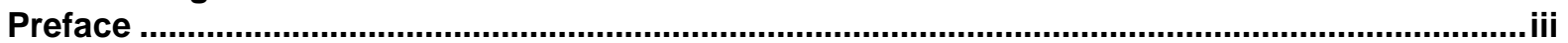

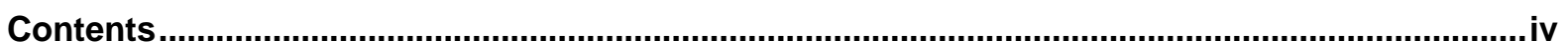

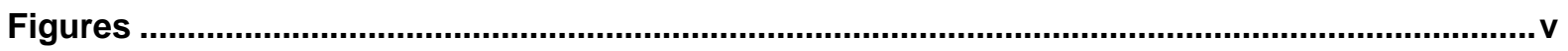

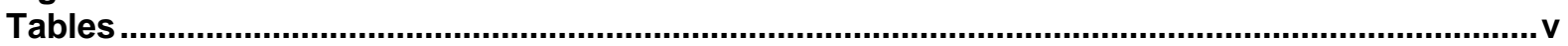

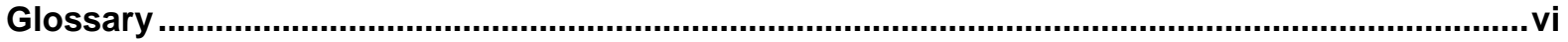

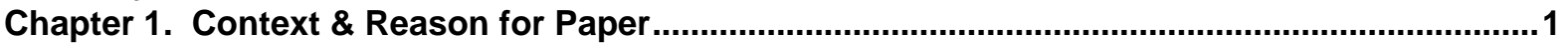

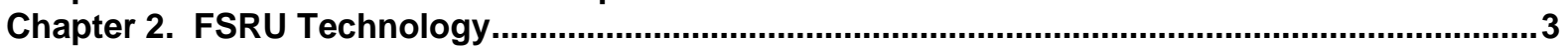

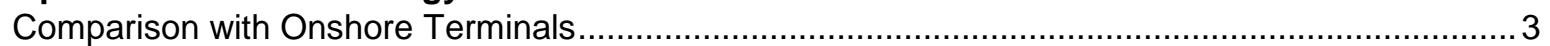

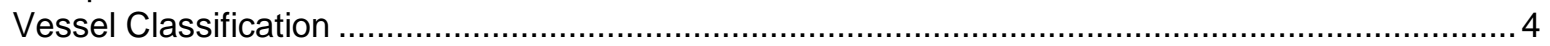

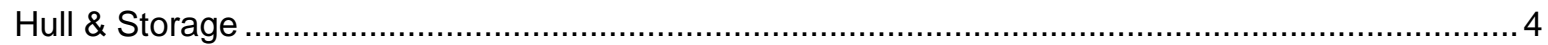

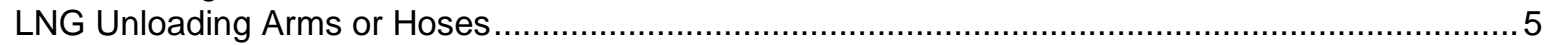

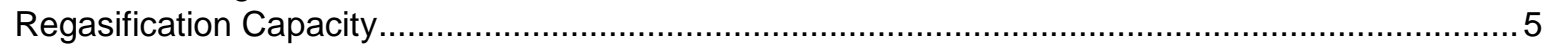

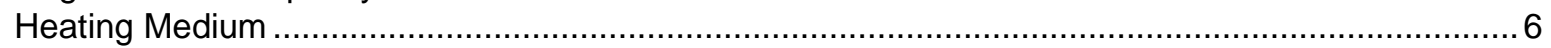

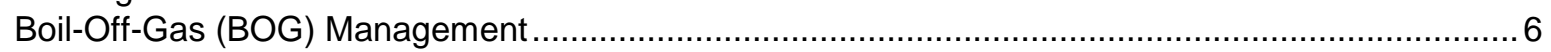

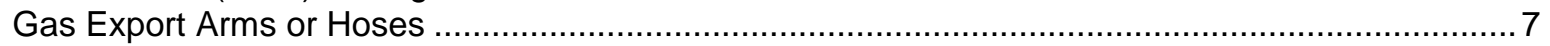

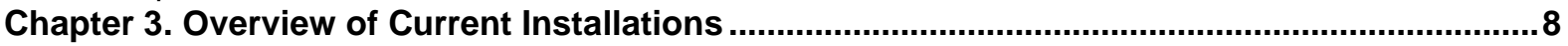

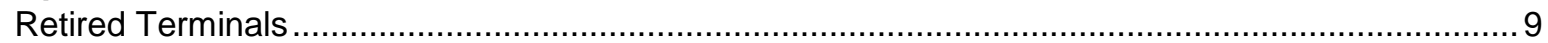

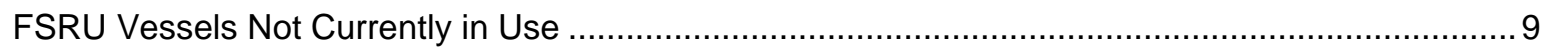

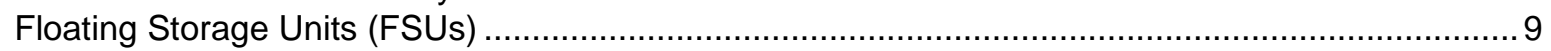

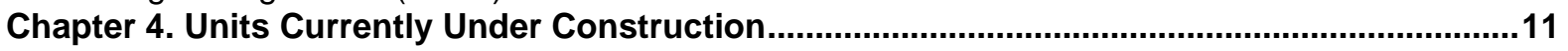

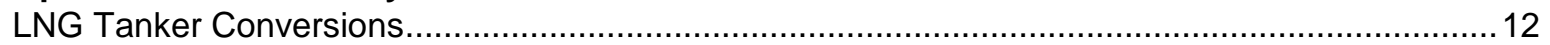

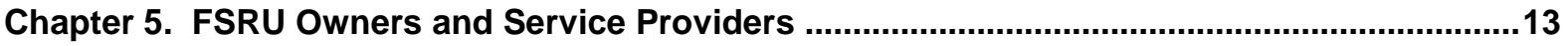

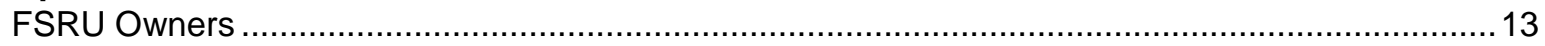

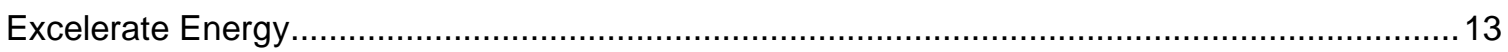

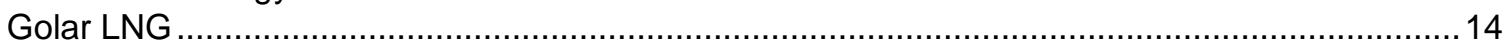

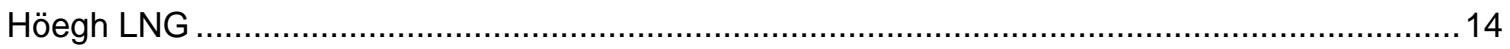

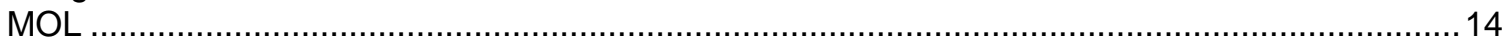

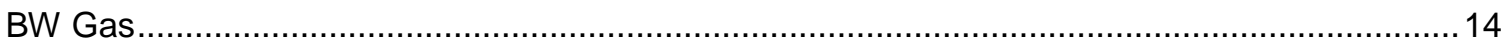

Maran Gas Maritime

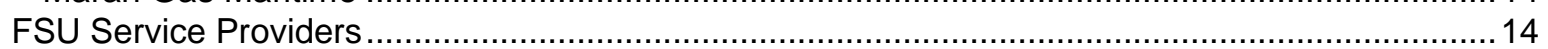

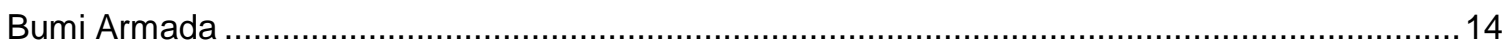

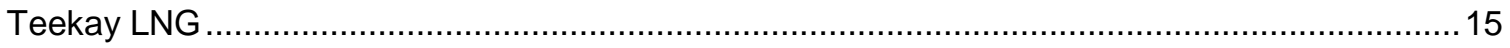

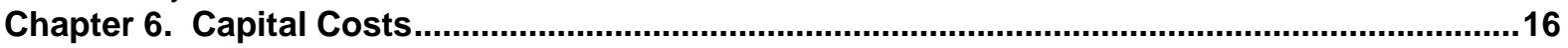

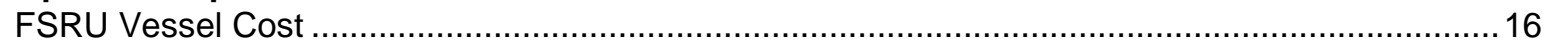

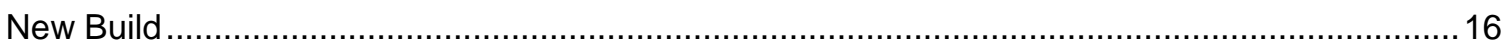

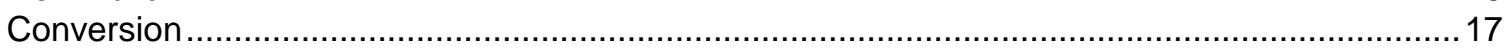

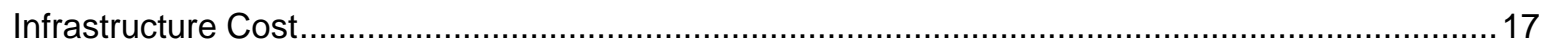

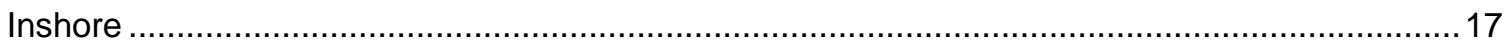

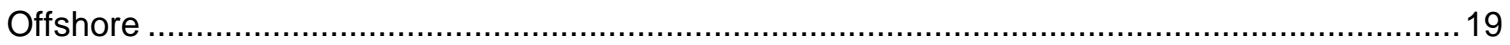

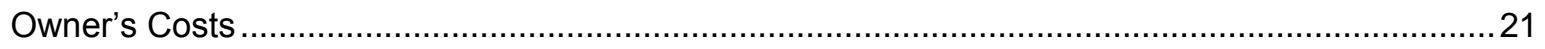

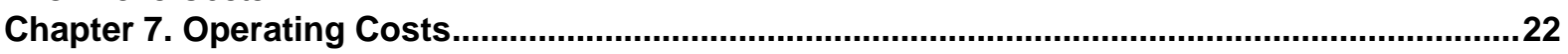

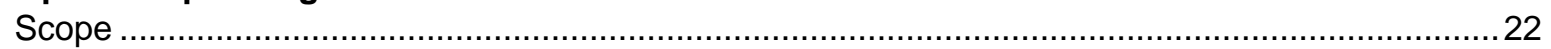

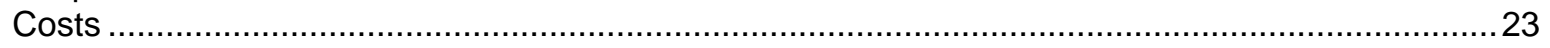

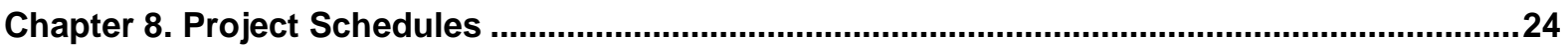

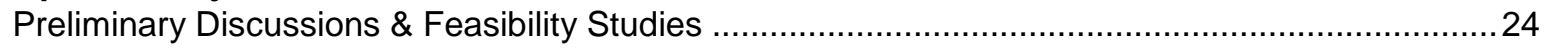

Permitting \& Pre-Engineering to Achieve Project Approval (FID) ................................................ 24

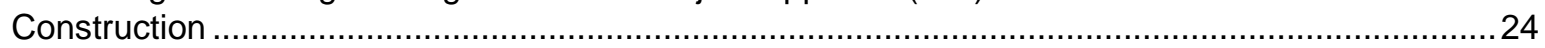

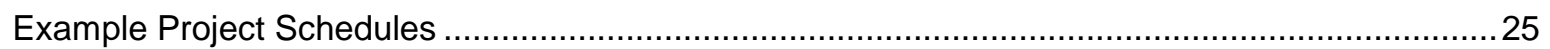

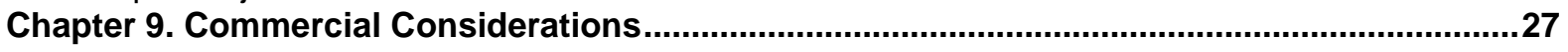

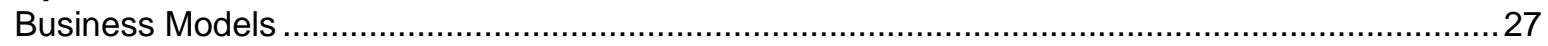

July 2017: The Outlook for Floating Storage and Regasification Units (FSRUs) iv 

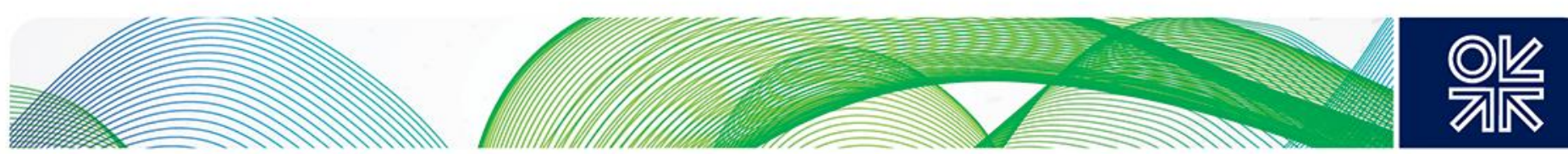

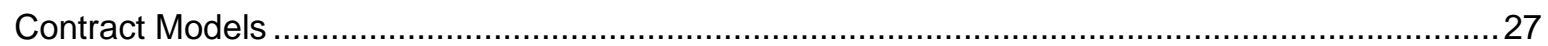

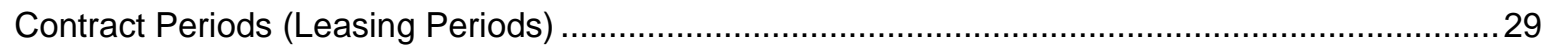

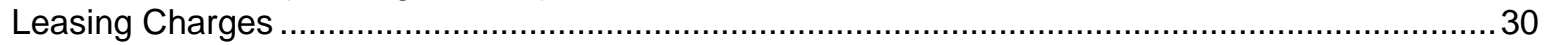

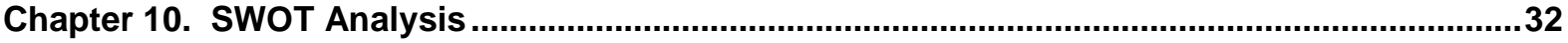

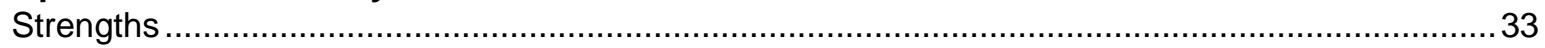

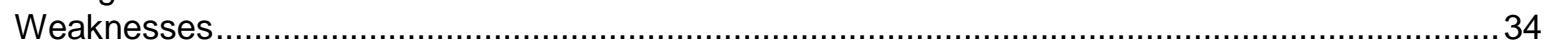

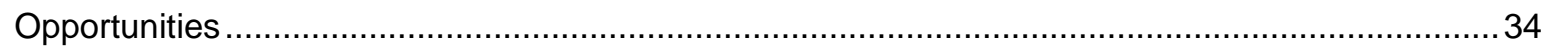

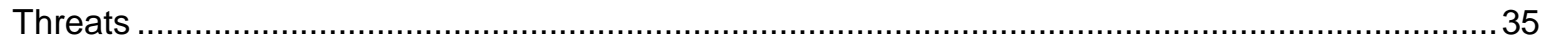

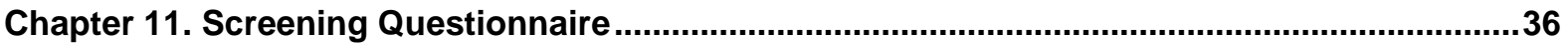

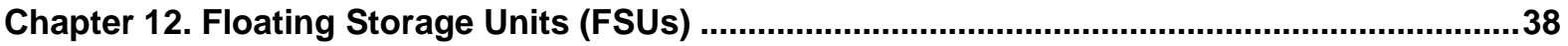

Chapter 13. Floating Power Barges ..............................................................................................40

Chapter 14. Conclusions .............................................................................................................41

Appendix 1. Current FSRU Fleet Details...................................................................................43

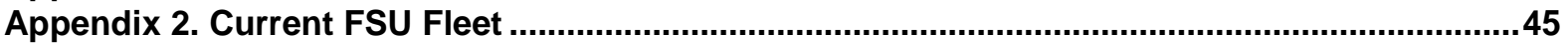

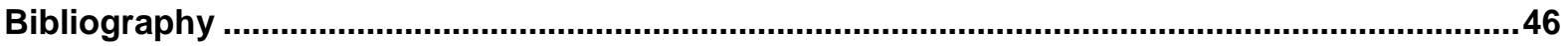

\section{Figures}

Figure 2.1 Typical FSRU Flow Scheme ......................................................................................... 3

Figure 2.2 Membrane Tanks Showing Regas Facilities on the Deck...........................................4

Figure 2.3 Moss Tanks with Regas Facilities Located Between the Tanks ..................................5

Figure 2.4 Moss Tanker with Regas Facilities Located on the Bow ...........................................5

Figure 4.1 Samsung Shipyard, Korea ..................................................................................12

Figure 5.1 Number of FSRUs by service provider .....................................................................13

Figure 6.1 Klaipeda FSRU Terminal Showing Jetty and Moorings .............................................18

Figure 6.2 GNL Escobar Terminal Argentina ...........................................................................19

Figure 6.3 Submerged Turret .....................................................................................................20

Figure 6.4 Surface Turret - Lampung, Indonesia ................................................................20

Figure 8.1 Project Schedules in Months..................................................................................25

Figure 9.1 Business Models....................................................................................................27

Figure 9.2 Contract Structure and Credit Support Mechanisms .....................................................28

Figure 9.3 Contract Structure and Credit Support Mechanisms .....................................................29

\section{Tables}

Table 3.1 Current Terminals ................................................................................................ 8

Table 3.2 Retired Terminals ...........................................................................................................9

Table 3.4 FSUs..........................................................................................................................10

Table 4.1 FSRUs in Construction .......................................................................................11

Table 6.1 CAPEX Comparison for Onshore Terminal and FSRU ..................................................16

Table 6.2 Recent New Build FSRU Contract Values .................................................................17

Table 8.1 FSRU Construction Schedules ..............................................................................25

Table 8.2 BW Gas - Fast track project - First gas in just 5 months.............................................26

Table 9.1 Lease Contract Duration Examples ..........................................................................30

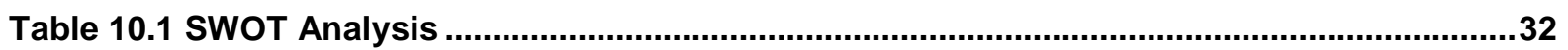

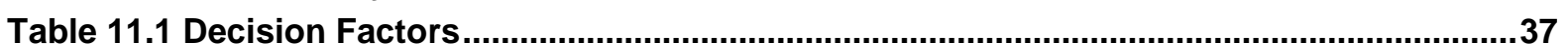

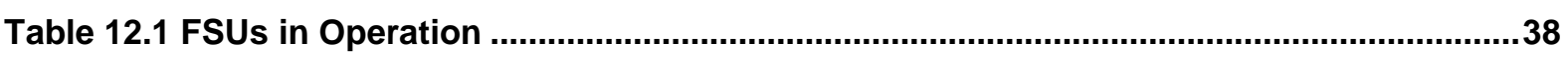



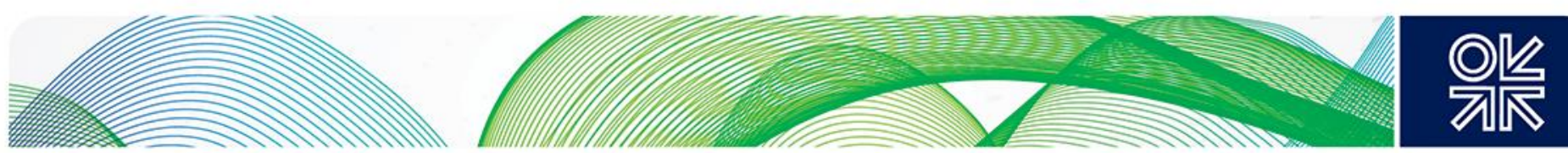

\section{Glossary}

bar $\mathrm{g}$ - unit of pressure close to 1 atmosphere

Bcfd - Billion cubic feet per day. A flowrate or production output of typically natural gas commonly used in North America

Bcma - Billion cubic metres per annum. A flowrate or production output of natural gas commonly used internationally

BOG - Boil Off Gas

BW Gas, BW Offshore - Part of the BW Group shipping company

Capex or CAPEX - Industry term for Capital Expenditure

Closed loop - Circulation of heating medium (typically glycol/water) for LNG regasification in heat exchangers

Hoses - cryogenic hoses used to transfer LNG at ca. minus $162^{\circ} \mathrm{C}$ ). Used mainly for ship to ship transfer as an alternative to more expensive mechanical arms.

DSME - Daewoo Shipbuilding \& Marine Engineering

EPC - Engineering, Procurement and Construction

Excelerate - Excelerate Energy

FEED - Front End Engineering Design

FID - Final Investment Decision - Typically made by the investors in an LNG project when all necessary sales contracts and other government and regulatory approvals are in place.

FLNG - Floating LNG liquefaction vessel

FPSO - Floating Production Storage \& Offloading Vessel

FSRU - Floating storage and regasification vessel

FSU - Floating Storage Unit

Golar - Golar LNG (LNG tanker company)

$\mathrm{HHI}$ or Hyundai - Hyundai Heavy Industries

Höegh - Höegh LNG (LNG tanker company)

HP - High Pressure (HP Pumps)

IFV - Intermediate Fluid Vaporisation - use of intermediate fluid (normally propane) for LNG vaporisation

km - kilometre

LNG - Liquefied Natural Gas

$\mathrm{m}^{3}-$ cubic metres

$\mathrm{m}^{3} / \mathrm{h}$ - Cubic metres per hour

Marinisation - Modification of equipment normally used onshore to be suitable for use in an offshore environment

Membrane - LNG thermal insulation method using stainless steel or Invar sheets in contact with LNG 

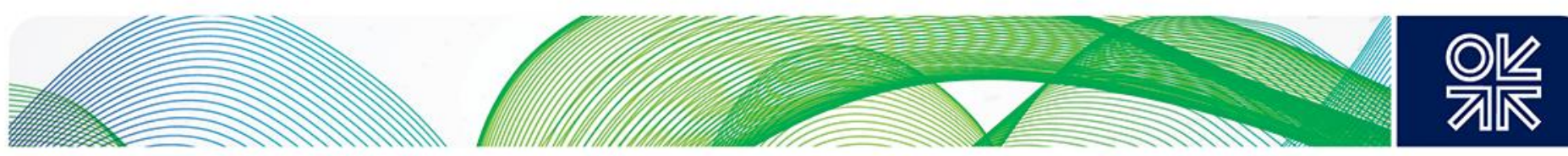

Mmscfd or mmscfd - Millions of standard cubic feet per day

MOL - Mitsui O.S.K. Lines

Moss - Moss Maritime LNG tank design using insulated spheres constructed from stainless steel or aluminium

mtpa - Millions of tonnes per annum

NIBY - Not in My Back Yard

Opex or OPEX - Industry term for Operating Expenditure

Open loop - direct vaporisation of LNG using sea water in heat exchangers

Qmax - Q-Max or Qatar Max - Large LNG Tanker with 266,000 $\mathrm{m}^{3}$ storage capacity

Recondenser - Vessel used to condense BOG by contact with super-cooled LNG

Regas - Regasification or vaporisation of LNG back into natural gas

Send-out - Production rate from an import terminal expressed as $\mathrm{m}^{3} / \mathrm{h}, \mathrm{t} / \mathrm{h}, \mathrm{mtpa}, \mathrm{mmscfd}$ or $\mathrm{Bcma}$

$\mathrm{SHI}$ or Samsung - Samsung Heavy Industries

STL - Submerged turret loading

STS - Ship to ship transfer

Side-by-side loading - Transfer of LNG when ships are moored side-by-side rather than across a jetty

SWOT - Strength Weaknesses Opportunities Threats

$\mathrm{t} / \mathrm{h}$ - Tonnes per hour

tpa - Tonnes per annum

\$ - US Dollar

$\$ / \mathrm{mmbtu}$ - US Dollars per million btus (unit of measurement for cost of regasification)

\$xxxm - xxx Millions of US Dollars 

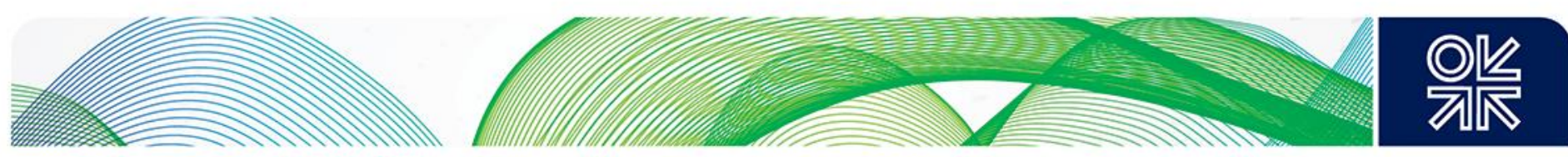

\section{Chapter 1. Context \& Reason for Paper}

The Floating Storage and Regasification (FSRU) business started just 16 years ago in 2001 when El Paso contracted with Excelerate Energy to build the first FSRU vessel for the Gulf Gateway project. Today there are 26 FSRU vessels of which 23 are operating as terminals and 3 as LNG tankers. A further 10 are currently in construction with options for another 10 placed with the shipyards. A recent IGU report estimated that close to 50 FSRUs could be in operation by 2025 with the capacity to import close to 200 mtpa i.e. $60 \%$ of the world's LNG production in 2016 . This is an incredible growth rate in an industry which is traditionally regarded as conservative and offers great opportunities to sell LNG into new markets. A further 67 prospects have been identified and are listed in this paper.

This rapid growth has been mainly due to the lower cost, faster schedule, commercial flexibility and reusable asset feature of FSRUs when compared to land based (onshore) terminals which cannot be relocated and must be regarded as a sunk cost. It is interesting to note that the pioneering FSRU projects - Gulf Gateway and Golar Spirit - had very different drivers. Gulf Gateway was developed by Excelerate Energy and used a new-build vessel based on technology developed by El Paso for a specific project. Conversely the Golar Spirit was the conversion of a 26 year-old LNG tanker undertaken on a purely speculative basis where Golar LNG could see the opportunity of adding value to the asset by changing its function. Both companies could see FSRUs offering a cheaper, faster and more flexible option than traditional onshore terminals. This success has been demonstrated by rapid take up with 26 vessels in 16 years.

Whilst the first FSRUs were based on nominal 130,000 $\mathrm{m}^{3}$ tankers with send out rates of 2-3 mtpa the more recent vessels are larger - typically $173,000 \mathrm{~m}^{3}$ and send out rates up to $6 \mathrm{mtpa}$. The FSRUs currently in construction offer the same full processing capability as land based terminals including full boil-off gas management facilities using recondensers.

The cost of a new FSRU can typically represent only $50-60 \%$ of an onshore terminal and be delivered in half the time. New builds typically cost $\$ 240-300 \mathrm{~m}$ and can be constructed in 27-36 months. FSRUs based on LNG tanker conversions cost less at £80-100m and the modifications typically take 18 months due to the long delivery times of the equipment not the shipyard conversion.

The time to first gas production depends on the availability of the FSRU vessel and the necessary ship/shore infrastructure required. For the vessel this is likely to be short as many FSRU owners have vessels becoming free from existing projects and many have ordered new vessels on a speculative basis. Some of the FSRU providers have stated they always want to be in a position to offer an available vessel to win the project. The infrastructure will be location specific. A recent example of offering a fast track project was the second Egypt FSRU that was completed in just 5 months.

By offering a low cost, fast track and flexible option when compared to traditional onshore terminals FSRUs offer an excellent opportunity to expand the LNG market internationally. An example is the expanding gas to power business being developed by smaller independent power companies who wish to serve developing nations by offering a clean and efficient source of fuel. Most of the current FSRU projects and prospects fall into this category.

This interest in gas to power has encouraged many FSRU companies to offer a complete package with power generation installed on the FSRU or on an adjacent barge. This would provide a one-stopshop solution which is ideal for the smaller independent companies.

In addition to FSRUs there are currently 4 floating storage vessels (FSUs) in operation, one in Malta and 2 in Malaysia. All are converted LNG tankers. There is also a small-scale FSU operating in Bali. A further FSU is currently being constructed for Bahrain LNG.

Please note that, due to the mobile nature of FSRUs, the information provided in this paper on the locations of the various vessels can change at short notice as owners reassign their assets. This is 

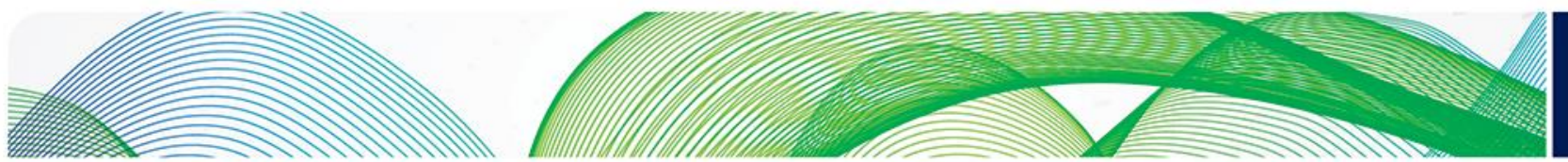

\section{OVI}

particularly relevant to those FSRUs that have been delivered to the terminal location but not yet commissioned. The information provided in this paper was accurate to the best of the author's knowledge as of $1^{\text {st }}$ July 2017. 

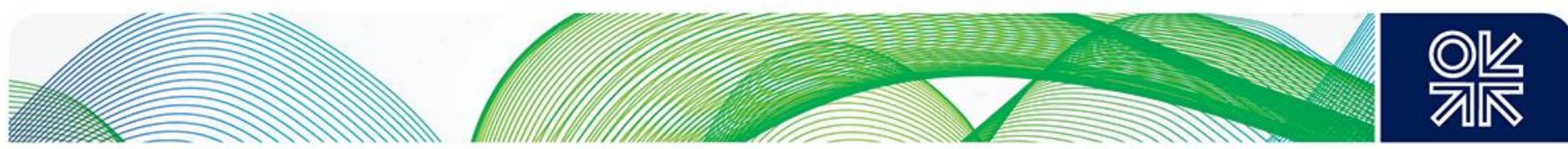

\section{Chapter 2. FSRU Technology}

\section{Comparison with Onshore Terminals}

FSRUs are based on LNG tankers and use essentially the same technology as onshore terminals. The only real difference is that the equipment is marinised ${ }^{1}$ to be suitable for shipyard construction and marine operation. For a new build vessel the equipment is normally integrated into the vessel and constructed with the ship - often referred to as 'piece small' or 'stick built'. For a conversion the equipment is normally built as a separate module or modules and retrofitted on to the tanker in a shipyard to minimize time.

A typical FSRU flow scheme is shown in figure 2.1.

Figure 2.1 Typical FSRU Flow Scheme

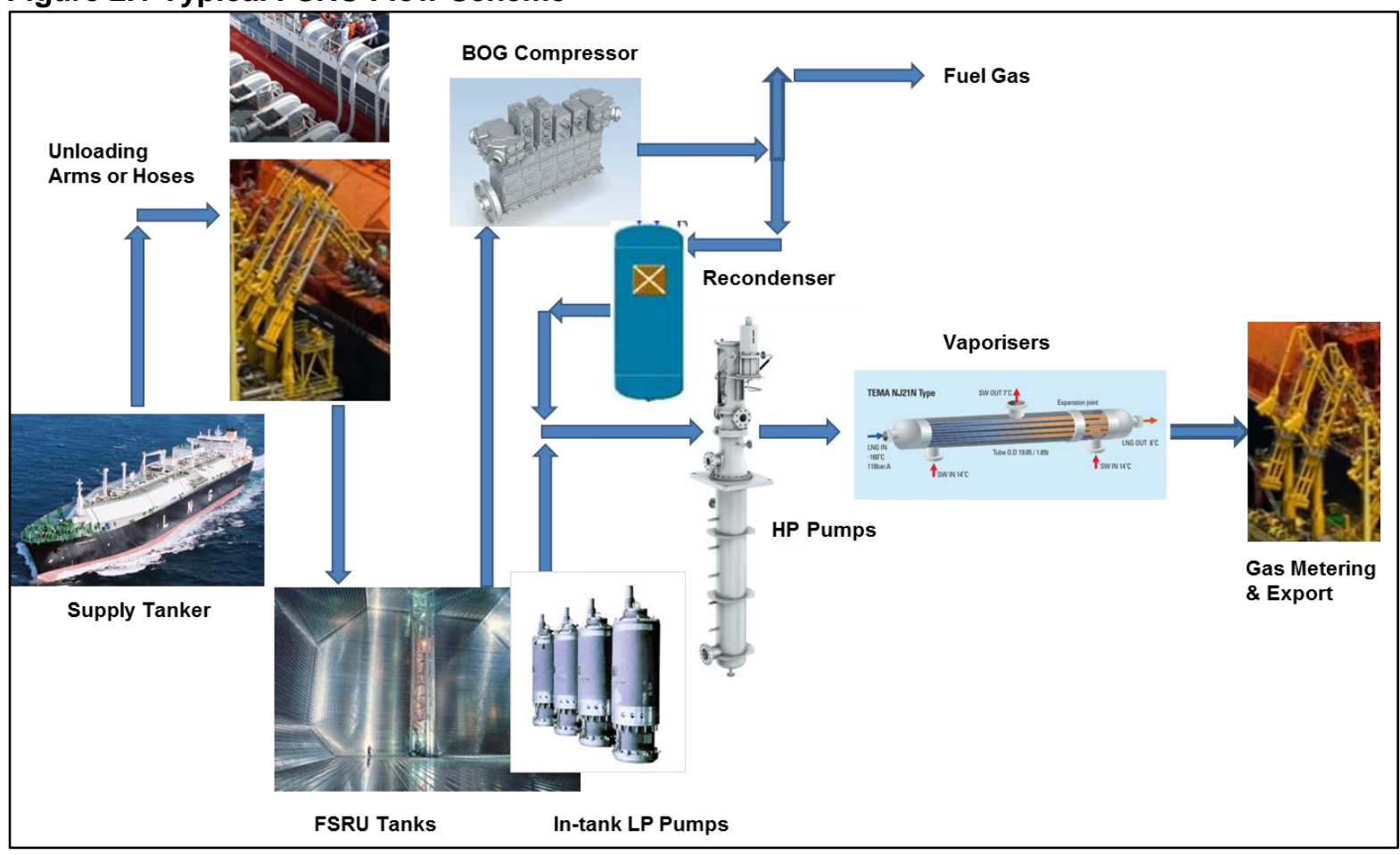

Source: By author

LNG is received via unloading arms or hoses, metered and stored in the tanks. The low pressure pumps located in the storage tanks send the LNG to the recondenser where it is contacted with compressed boil off gas from the storage tanks and the BOG is condensed back into LNG before entering the high pressure pumps. Some BOG is used as FSRU fuel and topped up if required by vaporised LNG. The fuel used is metered. Early FSRUs did not have recondensers and excess BOG was burnt in the ship's boilers and the steam was dumped to sea as condensate.

The high pressure pumps raise the pressure of the LNG from typically 5 bar $g$ to the export pressure required by the customer (e.g. typically 50 bar $\mathrm{g}$ for a power generation plant or 100 bar $\mathrm{g}$ for a gas network). The LNG is then vaporised at the export pressure, metered and exported via the gas export arm(s) or hoses to the export pipeline and the customer. 

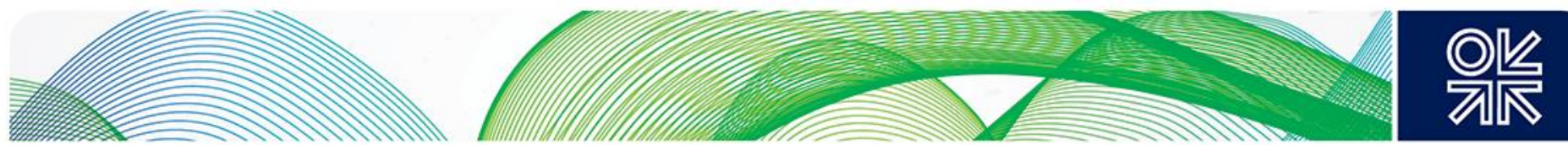

\section{Vessel Classification}

FSRU vessels can be classified either as ships or offshore installations. Ship design is based on normal worldwide LNG trading operation with regular dry docking and international marine safety standards. In the case of offshore installations these can be sub classified as mobile (with propulsion) or fixed (no propulsion). Offshore classified vessels are normally based on site specific conditions and regulated by national specifications and standards - an example being the FSRU Toscana ${ }^{2}$ which is a permanently moored installation located offshore Italy. Most FSRUs are classified as ships to provide the flexibility to operate either as an FSRU or LNG tanker.

\section{Hull \& Storage}

The hull and storage of an FSRU is identical to that of a normal LNG tanker. The vessels are constructed using a double steel hull for integrity and employ either membrane or spherical (Moss) type tanks. Of late, membrane tanks have been favoured for new build FSRUs as their shape provides a higher storage capacity for a given ship size because there are no spaces between the tanks. Also the flat deck provides a better platform for the regasification facilities as shown in figure 2.2. In the case of spherical tanks the regasification facilities have to be located either between the tanks as shown in figure 2.3 or on the bow as shown in figure 2.4. Many of the conversions are based on Moss type tankers.

\section{Figure 2.2 Membrane Tanks Showing Regas Facilities on the Deck}

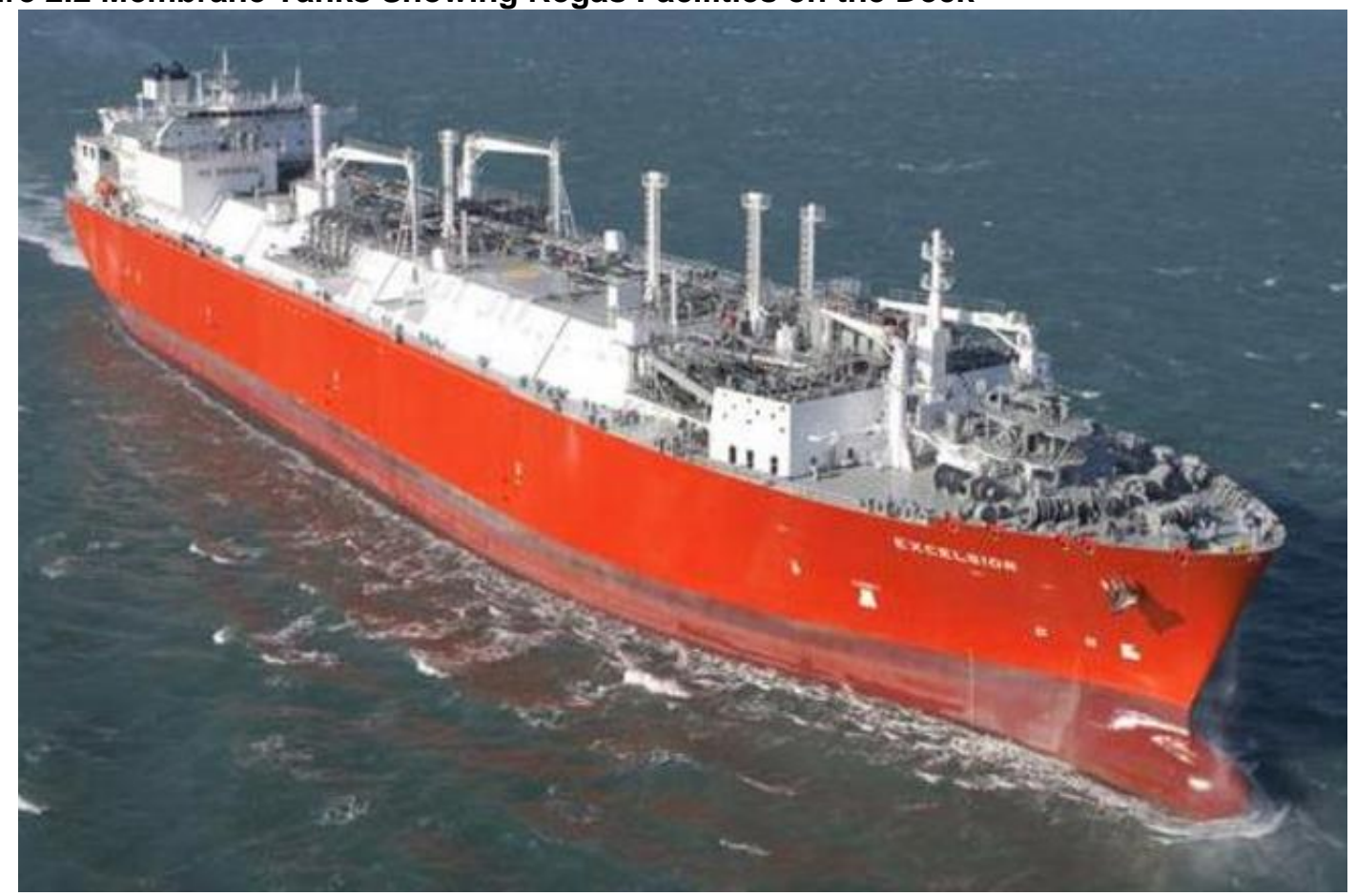

Source: Courtesy Excelerate Energy 

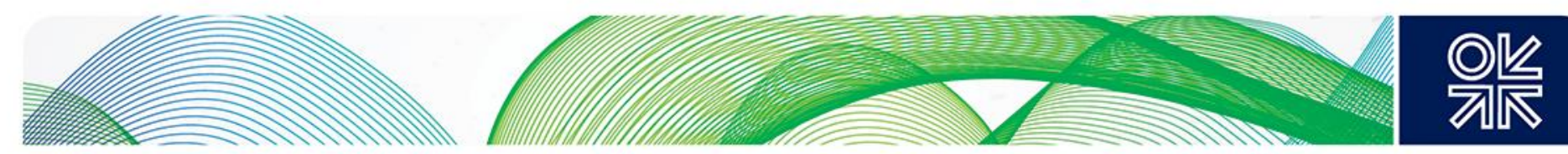

Figure 2.3 Moss Tanks with Regas Facilities Located Between the Tanks

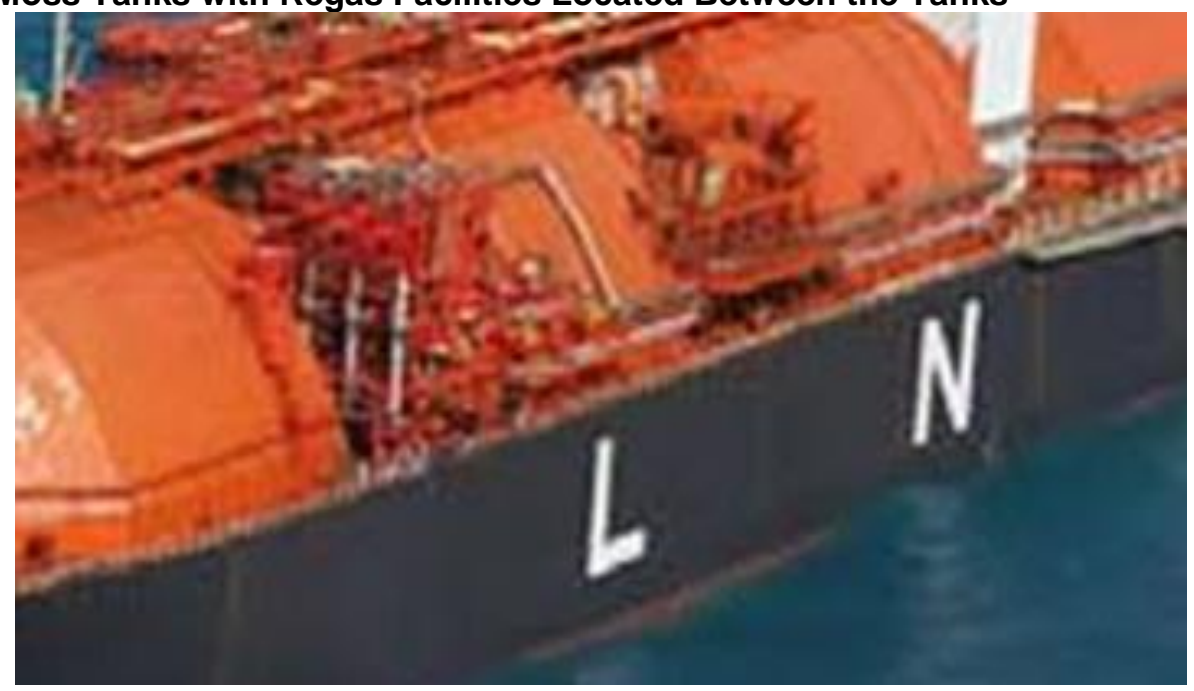

Source: Courtesy Golar LNG

Figure 2.4 Moss Tanker with Regas Facilities Located on the Bow

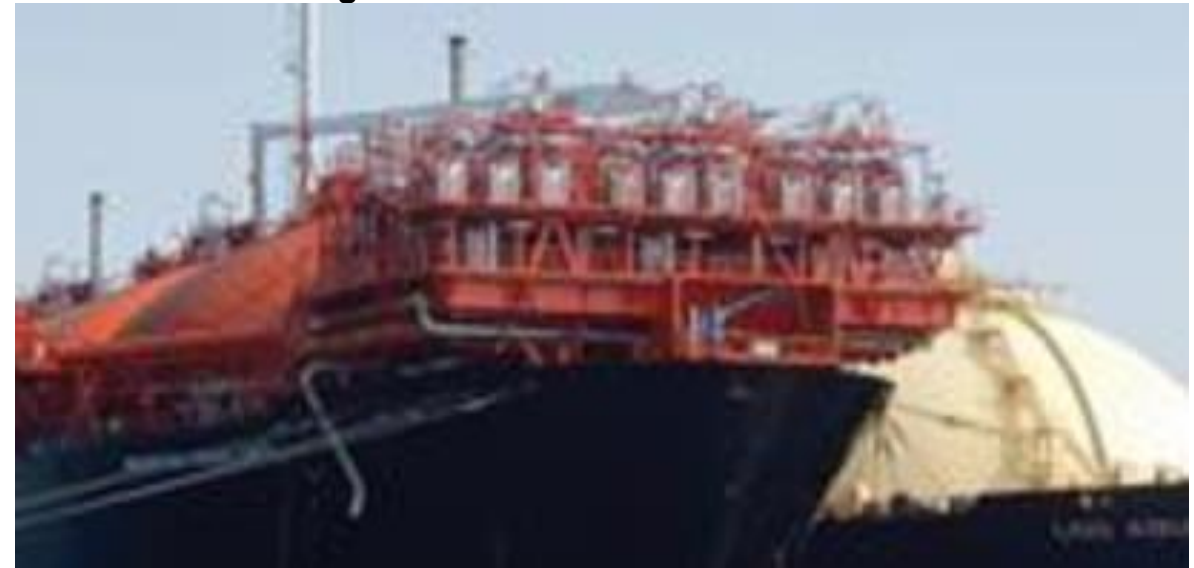

Source: Courtesy Golar LNG

\section{LNG Unloading Arms or Hoses}

LNG is most commonly transferred from the supply tanker using arms fitted on the FSRU but cryogenic hoses are also being used ${ }^{3}$. Over 1,000 transfers have been completed to date using hoses ${ }^{4}$. The main advantage of hoses is that they are much cheaper than cryogenic arms but the disadvantage is that offloading takes longer and generates more BOG.

\section{Regasification Capacity}

The early FSRUs were sized for send-out rates in the range of 200-400 mmscfd (1.7-3.4 mtpa) whereas more recent vessels have been sized for nearly twice that capacity at $600-700$ mmscfd (5-6 mtpa) to meet the demands of the market.

${ }^{3} \underline{\text { http://excelerateenergy.com/sts-Ing-transfer/ }}$ 

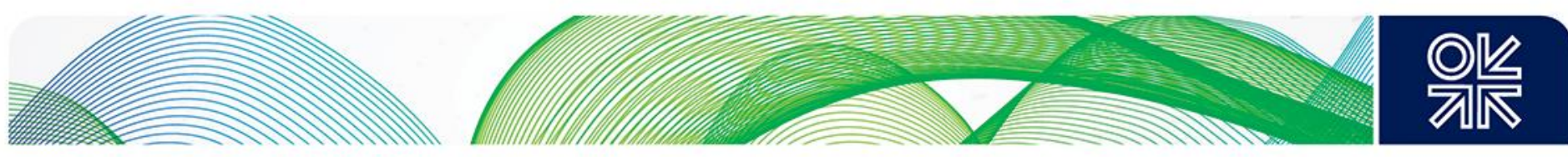

The smaller early vessels typically used $3 \times 33 \%$ or $3 \times 50 \%$ trains with each train using $2 \times 50 \%$ capacity pumps i.e. $6 \mathrm{HP}$ send-out pumps in total each with a capacity of $25 \%$ of the nominal send-out rate. The Excelerate Energy vessels used 6x20\% HP pumps.

For the $3 \times 50 \%$ train arrangement the $50 \%$ redundancy was accepted for these smaller capacity vessels as the technology was not fully proven. However the cost of installing $50 \%$ redundancy for the larger units can be $\$ 10-15$ million, which is significant, and hence there has been a move towards the use of just $3 \times 33 \%$ trains. A more optimal arrangement is to use $4 \times 33 \%$ trains which provides a higher availability and also better turn down flexibility. The $4 \times 33 \%$ arrangement was used on the 'Independence' for Lithuania probably to provide higher availability.

One perceived advantage of the spare capacity is to use it to meet the needs of a peak send out rate ${ }^{5}$ but this assumes that there is spare capacity in the heating fluid system capacity and the power generation capacity to drive the pumps. This is not generally the case and must be checked on a vessel by vessel basis.

\section{Heating Medium}

The LNG is vaporised in heat exchangers using an open loop system or a closed loop system. For the open loop system the sea water passes once through and returns to the sea in the same way as open rack vaporisers in onshore terminals. The closed loop system uses a circulating heating medium typically a fresh water/glycol mixture - which is heated by steam from the ship's boilers. This is similar to the submerged combustion vaporiser approach used on onshore terminals. There is also the option to use the intermediate fluid vaporisation process (IFV).

The open loop system is the simplest and uses direct sea water in a shell and tube heat exchanger. Seawater is pumped to the heat exchanger, vaporises the LNG and leaves approximately $10^{\circ} \mathrm{C}$ colder. This is better suited to warm seawater climates to minimise the risk of freezing the seawater. The sea water is returned directly to the sea - 'open loop'. This open loop approach can cause permitting issues in the same way as for onshore terminals. The energy used to pump the sea water through the heat exchanger consumes about $1.5 \%$ of the send out gas for power generation, similar to onshore terminals.

The closed loop system circulates a fresh water/glycol medium which is pre-heated by steam from the ship's boilers typically in a compact heat exchanger. This method uses a further $1 \%$ of the send out gas to heat the circulating fluid to vaporise the LNG i.e. a total consumption of $2.5 \%$.

The IFV system can be either in open loop or closed loop mode but the vaporisation takes place in 2 stages - the first with propane vapour which condenses and the second with the seawater or heating medium which cools. The propane is re-vaporised using the warm seawater or the heating medium. The advantages of this system are that it reduces the risk of freezing by not contacting the LNG with sea water and can also use compact heat exchangers reducing weight and size. The major disadvantage is the introduction of highly flammable propane on to the FSRU.

To meet the varying needs of different locations and provide flexibility there is a trend for new build vessels to have both open and closed loop capability. If seawater discharge directly into the harbour is permitted by the local authorities its use is preferred as it uses considerably less fuel, resulting in lower operating costs and lower $\mathrm{CO}_{2}$ emissions.

\section{Boil-Off-Gas (BOG) Management}

During normal operation (holding mode - no loading) the BOG generated from the LNG in the tanks is typically $0.10-0.15 \%$ by weight per day (ca $3-5 \mathrm{t} / \mathrm{h}$ ) depending on the age of the vessel. Modern vessels have better insulation and are closer to $0.1 \%$. BOG is used as fuel in the ship's utility

\footnotetext{
${ }^{5}$ Peak send out rate refers to short term higher production rates to meet market demand. This uses the spare capacity within the equipment for short periods only.
} 

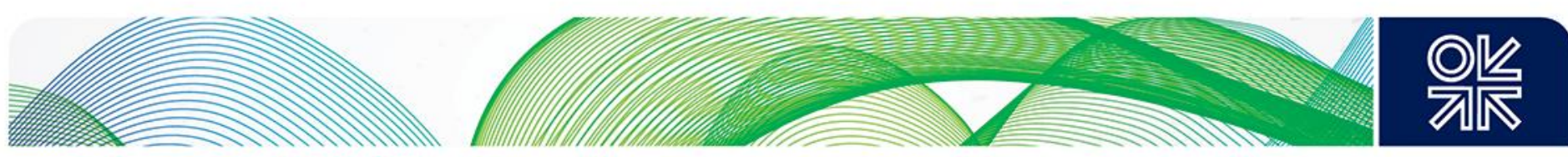

systems. For a $5 \mathrm{mtpa}$ send out rate using a closed loop system the typical fuel consumption would be $6 \mathrm{t} / \mathrm{h}$ for power generation, $14 \mathrm{t} / \mathrm{h}$ for heating the circulating fluid to vaporise the $\mathrm{LNG}$ and $0.5 \mathrm{t} / \mathrm{h}$ for general vessel services i.e. a total of $20.5 \mathrm{t} / \mathrm{h}$. If the FSRU uses the open loop method only $6 \mathrm{t} / \mathrm{h}$ of gas is required to generate the electrical power for the sea water circulation pumps plus general services i.e. total of $6.5 \mathrm{t} / \mathrm{h}$.

This additional gas required over and above that from BOG during holding mode will be generated by vaporising LNG. For a newer FSRU generating only $3 \mathrm{t} / \mathrm{h}$ BOG the make-up will be $3.5 \mathrm{t} / \mathrm{h}$ for open loop and $17.5 \mathrm{t} / \mathrm{h}$ for closed loop. In the case of an older $140,000 \mathrm{~m}^{3}$ tanker operating at $3 \mathrm{mtpa}$ sendout in open loop mode the BOG produced, approximately $5 \mathrm{t} / \mathrm{h}$, matches the fuel consumption.

However, during the LNG loading operation excess BOG is generated in the FSRU piping in just the same way as when filling onshore tanks. Whilst some of the gas is returned to the supply tanker to fill the space previously occupied by the LNG the excess gas needs to be managed. In the case of the early smaller FSRUs the excess gas was burnt in the ship's boilers and disposed of (dumped) as steam in the condensers.

More recent FSRUs recover this excess by the use recondensers in the same way as onshore terminals. The BOG is contacted with the LNG from the LP pumps and condenses back into LNG before entering the HP pumps and the vaporisers.

As for onshore terminals, the recondenser can only operate if there is send out from the FSRU and this needs to be managed i.e. the ship loading operation needs to coincide with gas send out. If this is not possible then an export compressor ${ }^{6}$ can be used to raise the BOG pressure from typically 5 bar $\mathrm{g}$ to the export pressure. An export compressor is used on the Golar Freeze for the Dubai FSRU terminal ${ }^{7}$.

\section{Gas Export Arms or Hoses}

For inshore FSRUs gas is exported via a high pressure gas export arm(s) ${ }^{8}$ but hoses can also be used, as is the case at the Nasantara FSRU in Indonesia9 ${ }^{9}$

For offshore (open water) locations the gas is exported via a submerged turret loading system ${ }^{10}$ (STL) or an articulated arm which also provides the vessel mooring system. Not all FSRUs are fitted with submerged turrets. The first 9 vessels in the Excelerate Energy fleet are all fitted with submerged turrets as are the Höegh LNG SRV vessels GdF Suez Cape Ann and Neptune. The most recent Excelerate Experience is not.

\footnotetext{
${ }^{6}$ https://www.burckhardtcompression.com/solution/marine/fsru-bog-handling/

7 https://www.burckhardtcompression.com/press-release/burckhardt-compressions-laby-gi-successfully-commissioned-golarsfsru-dubai/

${ }^{8}$ http://www.emcowheaton.com/marine-loading-arms/

http://www.wartsila.com/resources/customer-references/view/nusantara-regas-satu-fsru

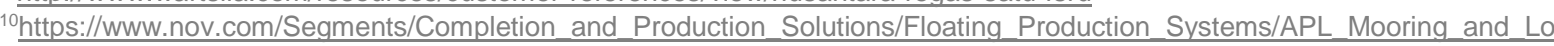
ading Systems/Submerged Turret Loading.aspx
} 


\section{Chapter 3. Overview of Current Installations}

There are currently 23 FSRU terminals operating world-wide. These are sorted by startup date in Table 3.1.

\section{Table 3.1 Current Terminals}

\begin{tabular}{|c|c|c|c|c|c|c|}
\hline Terminal & Location & Current Vessel & Storage $\mathrm{m} 3$ & $\begin{array}{l}\text { Nominal } \\
\text { mmscfd }\end{array}$ & $\begin{array}{c}\text { Nominal } \\
\text { mtpa }\end{array}$ & Start-up \\
\hline Northeast Gateway & USA & $\begin{array}{c}\text { Deepwater Port } \\
\text { (2 Buoys - No permanent vessel) }\end{array}$ & - & 600 & 5.0 & 2008 \\
\hline Bahia Blanca & Argentina & Exemplar & 138,000 & 500 & 4.1 & 2008 \\
\hline Pecem & Brazil & Golar Spirit & 129,000 & 240 & 2.0 & 2008 \\
\hline Guanabara Bay & Brazil & $\begin{array}{c}\text { Experience } \\
\text { (Prior } 2014 \text { other vessels) }\end{array}$ & 173,400 & 700 & 5.8 & 2009 \\
\hline Buenos Aires & Argentina & Exquisite & 149,700 & 500 & 4.1 & 2011 \\
\hline Jakarta Bay & Indonesia & Nusantara Regas Satu & 125,000 & 485 & 4.0 & 2012 \\
\hline Hadera & Israel & Excellence & 138,000 & 500 & 4.1 & 2013 \\
\hline Tianjin & China & $\begin{array}{c}\text { Neo Energy } \\
\text { (Replaced Suez Cape Ann) }\end{array}$ & 149,700 & 500 & 4.1 & 2013 \\
\hline Bahia, Salvador & Brazil & Golar Winter & 138,000 & 500 & 4.1 & 2014 \\
\hline Mina Al Ahmadi Port & Kuwait & Golar Igloo & 170,000 & 500 & 4.1 & 2014 \\
\hline Klaipeda & Lithuania & Independence & 170,000 & 384 & 3.2 & 2014 \\
\hline Lampung, Sumatra & Indonesia & PGN Lampung & 170,000 & 360 & 3.0 & 2014 \\
\hline Offshore Livorno & Italy & $\begin{array}{c}\text { FSRU Toscana } \\
\text { (Golar Frost) }\end{array}$ & 137,500 & 530 & 4.4 & 2014 \\
\hline Jebel Ali & Dubai & $\begin{array}{c}\text { Explorer } \\
\text { (Replaced Golar Freeze) }\end{array}$ & 151,000 & 500 & 4.1 & 2015 \\
\hline Port Qasim 1 & Pakistan & Exquisite & 151,000 & 500 & 4.1 & 2015 \\
\hline Ain Sokhna 1 & Egypt & Gallant & 170,000 & 500 & 4.1 & 2015 \\
\hline Aqabar & Jordan & Golar Eskimo & 160,000 & 500 & 4.1 & 2015 \\
\hline Ain Sokhna 2 & Egypt & BW Singapore & 170,000 & 500 & 4.1 & 2016 \\
\hline Ruwais & Abu Dhabi & Excelerate & 138,000 & 500 & 4.1 & 2016 \\
\hline Aliaga, Izmir & Turkey & $\begin{array}{l}\text { FSRU Neptune } \\
\text { (GdF Suez Neptune) }\end{array}$ & 145,000 & 500 & 4.1 & 2016 \\
\hline Cartagena & Colombia & Grace & 170,000 & 500 & 4.1 & 2017 \\
\hline Aguirre & Puerto Rico & $\begin{array}{c}\text { Expedient } \\
\text { (Proposed) }\end{array}$ & 138,000 & 500 & 4.1 & 2018 \\
\hline Punta de Sayago & Uruguay & GNL Del Plata & 263,000 & 500 & 4.1 & 2018 \\
\hline Tema & Ghana & $\begin{array}{c}\text { Golar Tundra } \\
\text { (Pending Final Contract) }\end{array}$ & 170,000 & 350 & 2.9 & 2018 \\
\hline
\end{tabular}

Source: By author 

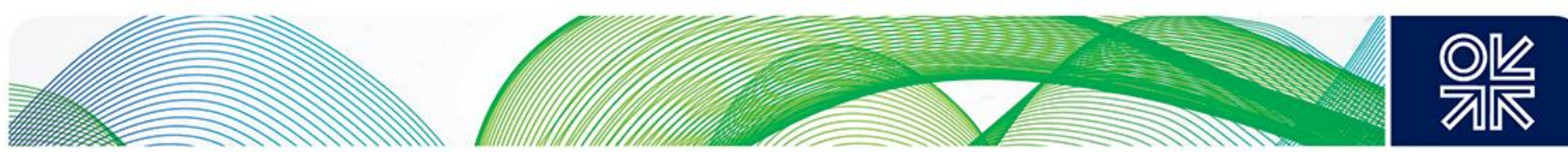

In all cases the vessel is on location but not all terminals have yet started up i.e. those in Ghana, Turkey and Uruguay. The use of 'current vessel' refers to the current FSRU at the terminal. It should be noted that FSRU providers can replace vessels to meet changing needs e.g. capacity changes. This was the case at Guanabara Bay in Brazil where the terminal started operation in 2009 but the vessel was replaced with the larger Experience in 2014. One of key features of FSRUs is they can be relocated to match market needs.

Recent reports state that the Pecem terminal in Brazil may close in late June $2017^{11}$ and possibly be replaced by an onshore terminal. This is an example of how an FSRU can provide an early gas option prior to a decision to build a permanent onshore terminal.

\section{Retired Terminals}

Some of the very early FSRU terminals have now retired as shown in Table 3.2. The North East Gateway, Gulf Gateway and Teesside terminals were operated by Excelerate Energy and supplied by various tankers in the Excelerate fleet. In the case of the Neptune the 'Neptune SRV' was assigned but has recently been moved to Turkey for the Aliaga FSRU terminal project. This demonstrates the flexibility of the FSRU concept.

\section{Table 3.2 Retired Terminals}

\begin{tabular}{|c|c|c|c|}
\hline Terminal & Location & $\begin{array}{c}\text { Charter } \\
\text { Company }\end{array}$ & Vessel \\
\hline Gulf Gateway & USA & $\begin{array}{c}\text { Excelerate } \\
\text { Energy }\end{array}$ & Various \\
\hline Neptune & USA & Höegh LNG & Neptune SRV \\
\hline Teesside & UK & $\begin{array}{c}\text { Excelerate } \\
\text { Energy }\end{array}$ & Various \\
\hline
\end{tabular}

Source: By author

These terminals have been retired due to lack of gas demand in the markets that they served e.g. USA with imports replaced by domestically produced shale gas,

\section{FSRU Vessels Not Currently in Use}

In addition to the 23 FSRUs currently operating as terminals as listed in Table 3.1 only one other FRSU the Excelerate Express (storage capacity of $150,900 \mathrm{~m} 3$ and a send out rate $550 \mathrm{mmscfd}$ ) is not allocated to a specific terminal and is currently operating in LNG Tanker service. This completes the list of the current 24 FSRU vessels in operation.

\section{Floating Storage Units (FSUs)}

In addition to FSRUs, there are four floating storage units (FSUs) currently in operation as listed in Table 3.4. 

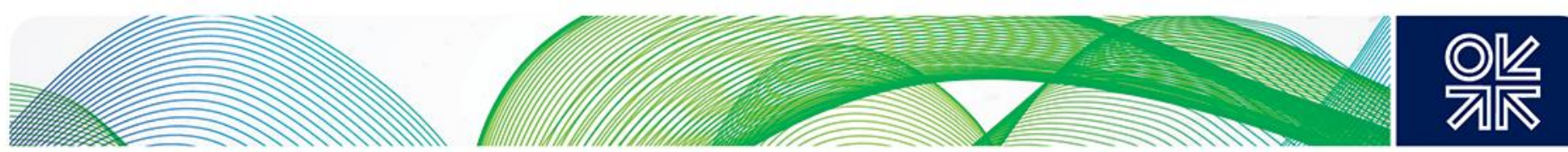

Table 3.4 FSUs

\begin{tabular}{|c|c|c|r|c|}
\hline Terminal & Location & Vessel & Storage m3 & Start-up \\
\hline Kingston & Jamaica & Golar Arctic & 138,000 & 2016 \\
\hline Marsaxlokk Bay & Malta & Armada LNG Mediterrana & 125,000 & 2017 \\
\hline Melaka & Malaysia & Tenaga Satu & 130,000 & 2012 \\
\hline Melaka & Malaysia & Tenaga Empat & 130,000 & 2012 \\
\hline
\end{tabular}

Source: By author

FSUs provide an alternative to onshore LNG storage tanks. They are converted LNG tankers but without the onboard regasification facilities installed on FSRUs. Most are linked with the onshore regasification facilities or on a separate barge. FSUs offer the same advantages when compared to onshore storage tanks as FSRUs do to onshore terminals - shorter schedule and flexibility in terms of relocation, leasing and likely less permitting issues. Also a FSU is an ideal alternative where there is a shortage of land onshore.

A FSU conversion would probably take less than 12 months compared to typically $36-40$ months to construct an onshore tank i.e. a third of the time. Regarding cost a converted used 138,000 $\mathrm{m}^{3} \mathrm{LNG}$ tanker is likely to cost $\$ 100-150 \mathrm{~m}$ depending on its age compared to $\$ 140 \mathrm{~m}^{12}$ for the same sized onshore tank - so little capital cost advantage but a lower cost for short term operations due to leasing.

The first FSU was located at the Mejillones LNG terminal in Chile to provide early storage while the main LNG tanks were under construction ${ }^{13}$ using the BW GDF SUEZ Brussels, which was returned to normal LNG tanker service in 2014 when the second onshore tank was commissioned.

The FSU option for Jamaica is likely to be short term and it understood that an onshore terminal is planned for the longer term.

The FSU option for Malta was chosen on the basis of best economical solution ${ }^{14}$. The two FSUs located in Malaysia are converted 30 year old tankers ${ }^{15}$ that were already owned by Petronas and probably at the end of their economic life so very likely a lower cost option than onshore tanks.

A fifth FSU is currently being converted for Bahrain LNG. The vessel is a new $174,000 \mathrm{~m}^{3}$ Teekay LNG tanker. The terminal agreement is for 20 years ${ }^{16}$ so leasing provides an option before deciding on whether a permanent on shore terminal is required.

FSUs are discussed further in Chapter 12.

\footnotetext{
${ }^{12}$ Full containment LNG cost metric $\$ 1,000 / \mathrm{m}^{3}$. Single containment $\$ 700 / \mathrm{m} 3$ but industry now has a strong preference for full containment and regarded as best practice.

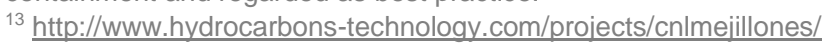

${ }^{14}$ http://bumiarmada.com/350 351 121/MobileWeb/WebPage/FSRU-FSU/Floating-Gas-Solutions.htm/

${ }^{15} \mathrm{https}: / /$ www.platts.com/latest-news/natural-gas/singapore/malaysias-melaka-Ing-terminal-receives-nigerian-27935752

${ }^{16}$ http://teekay.com/blog/2015/12/02/teekay-Ing-samsung-gic-sign-Ing-import-terminal-project-in-bahrain/
} 

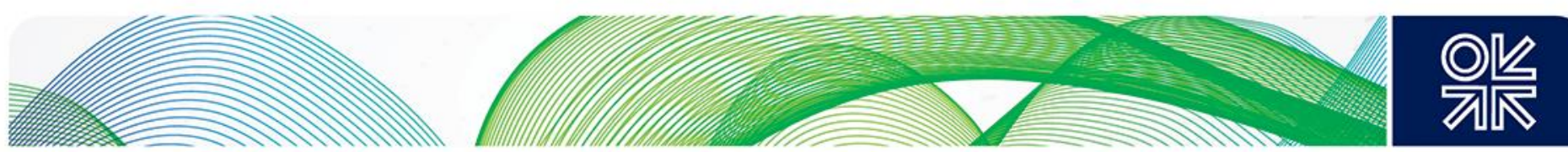

\section{Chapter 4. Units Currently Under Construction}

There are currently 10 FSRUs under construction as shown in Table 4.1. Nine are being constructed in Korea and one small barge unit in China. Four will be delivered this year and the remaining 6 between 2018 and 2020, bringing the total number of vessels in operation to 36 by the end of 2020 . The EXMAR project is a smaller barge shaped vessel.

It is interesting to note that most are being built on a speculative basis and this reflects the need to be competitive by offering a vessel on a fast track basis rather than wait for the construction time of 2736 months. This is an aggressive approach by the FSRU owners as the vessels typically cost $\$ 250$ $300 \mathrm{~m}$ but this risk is offset by the ability of the vessels to be assigned to LNG tanker service if no suitable FSRU terminal application is found. Indications are that prices are dropping ${ }^{17}$ closer to $\$ 250 \mathrm{~m}$.

The three main Korean yards - DSME, Hyundai and Samsung - dominate the market.

Table 4.1 FSRUs in Construction

\begin{tabular}{|c|c|c|c|c|c|c|c|}
\hline Shipyard & Owner & Name & Assigned & $\begin{array}{c}\text { Storage } \\
\mathbf{m}^{\mathbf{3}}\end{array}$ & mmscfd & mtpa & Completion \\
\hline Hyundai & Gazprom & Marshal Vaslevskiy & $\begin{array}{c}\text { Kaliningrad } \\
\text { FSRU }\end{array}$ & 174,100 & 600 & 5,0 & 2017 \\
\hline Hyundai & Höegh LNG & FSRU\#7 & Tema & 170,000 & 750 & 6.2 & 2017 \\
\hline Samsung & Golar LNG & $\begin{array}{l}\text { FSRU\#8 } \\
\text { Nanook }\end{array}$ & Brazil or Chile? & 170,000 & 440 & 3.7 & 2017 \\
\hline Wison & EXMAR & FSRU Barge \#1 & TBA & 26,230 & 600 & 5,0 & 2017 \\
\hline Hyundai & Höegh LNG & FSRU\#8 & TBA & 170,000 & 750 & 6.2 & 2018 \\
\hline Hyundai & Höegh LNG & FSRU\#9 & Port Qasim & 170,000 & 750 & 6.2 & 2018 \\
\hline DSME & BW Offshore & FSRU\#3 & TBA & 173,000 & n/a & n/a & 2019 \\
\hline Samsung & Höegh LNG & FSRU\#10 & TBA & 170,000 & 750 & 6.2 & 2019 \\
\hline Samsung & BW Offshore & Integrity & Port Qasim & 173,400 & 750 & 6.2 & 2019 \\
\hline DSME & Maran Gas Maritime & FSRU\#1 & TBA & 173,000 & n/a & n/a & 2020 \\
\hline
\end{tabular}

Source: By author

In addition to those on order, Excelerate Energy has options for 7 further vessels with DSME and Höegh LNG a further 3 vessels with Samsung i.e. a further 10 vessels. A photograph of the Samsung shipyard is included as figure 4.1 to indicate the scale of the facilities i.e. 4 vessels in one dry dock. 

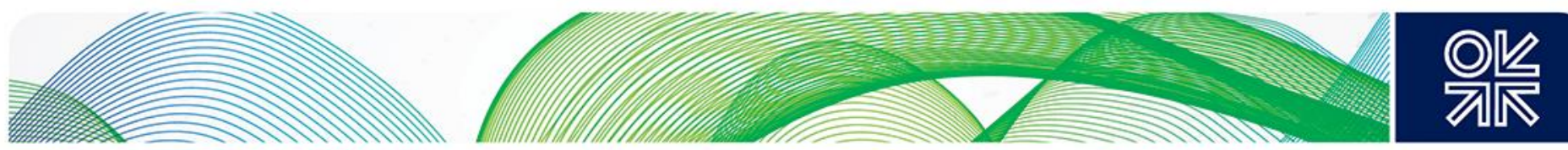

Figure 4.1 Samsung Shipyard, Korea

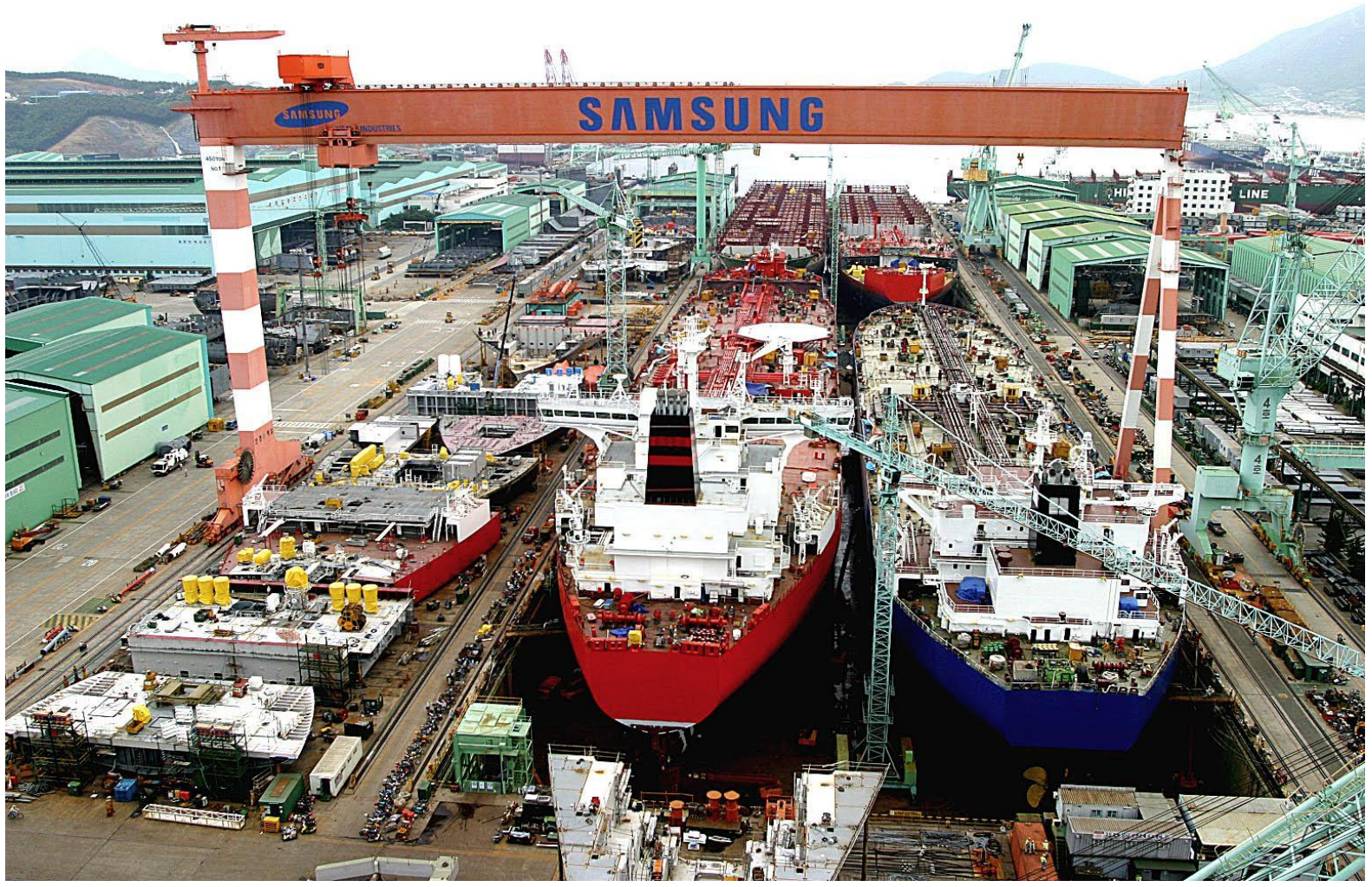

Source: Courtesy Samsung Heavy Industries

\section{LNG Tanker Conversions}

Many of the original FSRUs were based on Moss or Membrane LNG tanker conversions. ${ }^{18}$ The recent trend has been to construct new build vessels with typically $170,000 \mathrm{~m}^{3}$ storage and a $600-750$ mmscfd send out rate.

However, it is interesting to note that Höegh LNG has just placed an order with Maritime (engineering) and Wärtsila Oil and Gas ${ }^{19}$ for the conversion of an existing Moss tanker. It appears that the order is for the engineering and procurement of the long delivery equipment items only to enable physical conversion work to be completed in just 12 months rather than the normal 18 months if the equipment had to be ordered. Both of these conversion options are less than the 27-36 months required to construct a new vessel. The selected vessel has not been named but is likely to be one from Höegh's existing fleet. This conversion approach certainly makes sense if a shipping company has an existing vessel and can avoid the higher cost of a new vessel.

\footnotetext{
${ }^{18}$ Four of the original Golar LNG FSRUs were conversions - Golar Spirit, Golar Winter, Golar Freeze and the Golar Nusantara Regas Satu.

${ }^{19}$ https://www.Ingindustry.com/regasification/24082016/hoegh-signs-agreements-for-fsru-conversion-project-2946/
} 

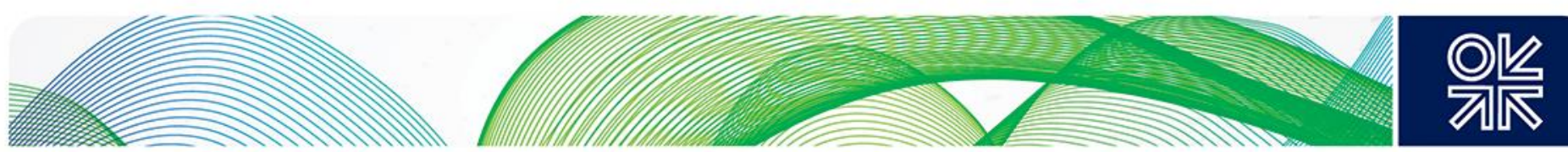

\section{Chapter 5. FSRU Owners and Service Providers}

\section{FSRU Owners}

The major FSRU owners are often referred to as service providers and are all well-established LNG tanker companies. The leading companies are Golar LNG, Höegh LNG and Excelerate Energy. Recently new companies have entered the market - BW Gas and Mitsui O.S.K. Lines (MOL). Figure 5.1 shows the number of operating FSRUs by service provider. Maran Gas Maritime has just ordered its first FSRU from DSME. OLT is not a service provider in the normal sense - the vessel was purchased from Golar LNG and is operated by the project with Golar LNG as a partner.

Figure 5.1 Number of FSRUs by service provider

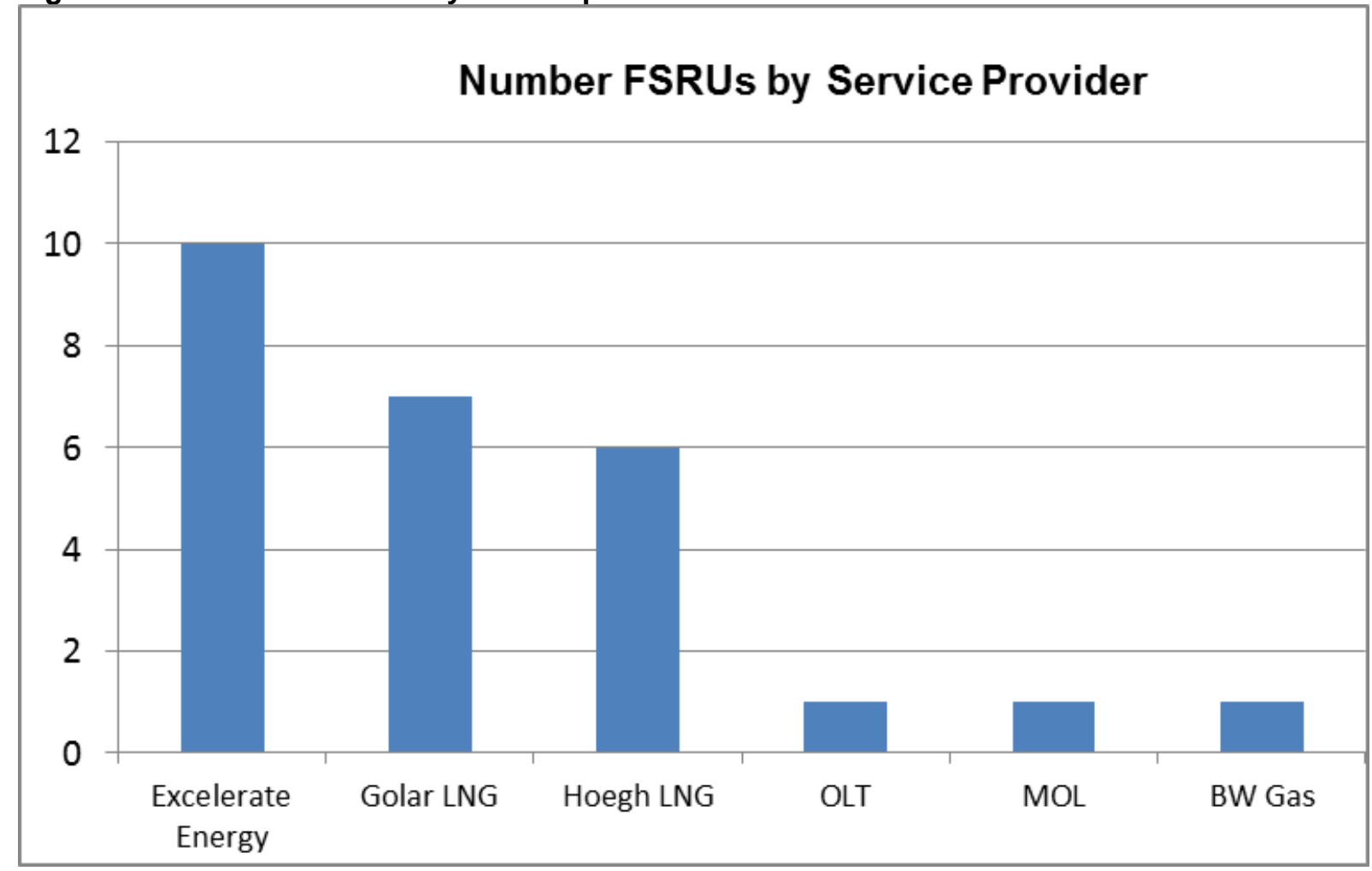

Source: By author

\section{Excelerate Energy ${ }^{20}$}

Excelerate Energy is based in the USA and was a pioneer of the FSRU concept with the Gulf Gateway project offshore Gulf of Mexico. It currently has 9 FSRU vessels operating either as FSRUs or LNG tankers and one dedicated conventional LNG tanker. A further eight vessels are under construction by DSME with a capacity of $173,000 \mathrm{~m}^{3}$ and a regas capacity in the range of 3-4 mtpa. Excelerate explored the possibility of entering the floating liquefaction business (FLNG) but withdrew and decided to focus on the FSRU business.

\footnotetext{
${ }^{20}$ http://excelerateenergy.com/fleet/
} 

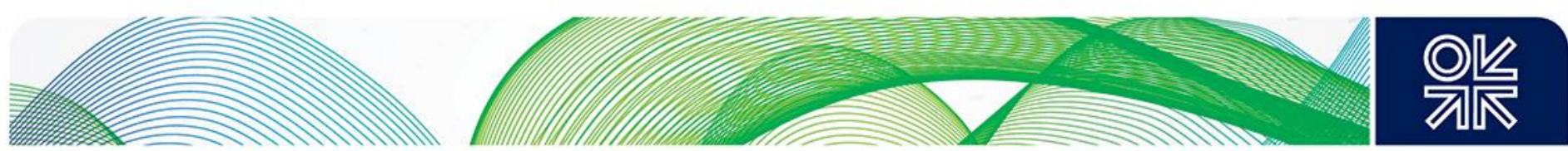

\section{Golar LNG21}

Golar LNG is based in Norway and operates 20 LNG tankers of which nine have been added to the fleet in the last two years. It has 7 FSRUs in operation and one more under construction by Samsung and due for delivery in late 2017. It is currently converting three of its LNG tankers into floating liquefaction vessels (FLNGs).

\section{Höegh LNG}

Höegh LNG is based in Norway and operates six FSRUs and 5 LNG tankers. Three further FSRUs are currently under construction. Like Excelerate Höegh LNG also considered entering the floating liquefaction business (FLNG) but withdrew and decided to focus on the FSRU and LNG tanker business.

\section{$M O L^{22}$}

Mitsui O.S.K. Lines (MOL) is based in Japan and is a major shipping company covering the full range of freight and passenger ships. It currently operates 18 LNG tankers and most recently added one FSRU - the Punta de Sayago ${ }^{23}$ based in Uruguay. This is currently the largest FSRU based on a Qmax LNG tanker with a storage capacity of $263,000 \mathrm{~m}^{3}$.

\section{BW Gas $^{24}$}

BW Gas is part of the BW Group based in Norway. It is one of the major FPSO providers and has 25 years' experience. It has delivered 28 FPSO projects and 10 FSO projects. It is currently working with Pangea LNG and pursuing the Noble King FLNG project in Israel. It also operates 17 LNG tankers with 4 more under construction. BW Gas has just supplied the second Egypt FSRU (BW Singapore) for Ain Sokhna and a further new build FSRU will be supplied for the second Port Qasim terminal in Pakistan, further establishing itself in the LNG supply chain.

\section{Maran Gas Maritime ${ }^{25}$}

Maran Gas Maritime is based in Greece and is part of the Maran Tankers ${ }^{26}$ group. It is just entering the FSRU market and has ordered one FSRU ${ }^{27}$ from DSME which is expected to be delivered in 2020. Like the other FSRU owners they are a major LNG shipping company and currently have a fleet of 26 LNG tankers and a further 6 on order.

\section{FSU Service Providers}

There are 4 FSUs currently in operation as detailed in chapter 12 and one under construction. Two are owned outright by Petronas and are on location in Melaka, Malaysia. The third (Golar Arctic) is owned by Golar LNG and is currently on location in Kingston, Jamaica. The fourth is owned by Bumi Armada and is on location in Marsaxlokk Bay, Malta. A fifth vessel is under construction for Teekay LNG and will be owned and operated by them for Bahrain LNG.

\section{Bumi Armada ${ }^{28}$}

Bumi Armada Berhad ("Bumi Armada") is a Malaysian based international offshore oil and gas services provider and has a fleet of 6 oil FPSOs. It has recently entered the LNG market with the

\footnotetext{
${ }^{21}$ http://www.golarlng.com/our-fleet/floating-storage-and-regasification-units

22 http://www.mol.co.jp/en/index.html

${ }^{23}$ http://www.mol.co.jp/en/pr/2016/16042.html

24 http://www.bw-group.com/our-business/bw-Ing/bw-gas-solutions

25 http://www.marangas.com/index.php?id=68

26 http://www.marantankers.gr/about-us.html

http://www.Ingworldnews.com/dsme-to-build-fsru-for-maran-gas/

${ }^{28}$ http://bumiarmada.com/350 351 121/MobileWeb/WebPage/FSRU-FSU/Floating-Gas-Solutions.html
} 

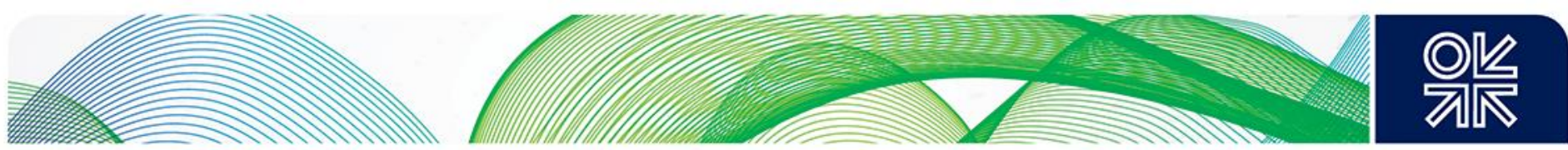

award of the Malta LNG FSU project and has been working with Keppel and IHI on possible floating liquefaction concepts.

\section{Teekay $L N G^{29}$}

Teekay entered the LNG shipping market in 2004 and is now one of the world's largest independent owners and operators with 50 LNG carriers. It also provides LPG and crude oil marine transportation services with 30 LPG/Multi-gas carriers and eight conventional tankers. 

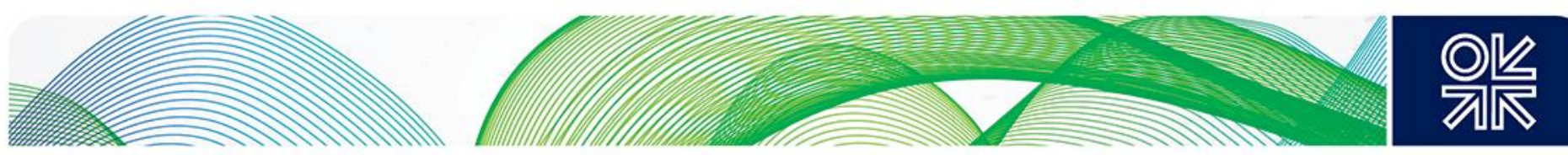

\section{Chapter 6. Capital Costs}

The capital cost of a new FSRU-based terminal can typically represent just $60 \%$ of an onshore terminal and can be delivered in a shorter time. An onshore $3 \mathrm{mtpa}$ terminal with one $180,000 \mathrm{~m}^{3}$ storage tank is likely to cost $\$ 700-800 \mathrm{~m}$, depending on local construction labour costs, compared to $\$ 400-500 \mathrm{~m}$ for a similar capacity FSRU. This comparison is summarised in table 6.1.

Table 6.1 CAPEX Comparison for Onshore Terminal and FSRU

\begin{tabular}{|l|c|c|}
\hline & \multicolumn{2}{|c|}{ 3 $\mathbf{~ m t p a , ~ 1 8 0 , 0 0 ~} \mathbf{~ m 3}$ storage } \\
\hline Component & Onshore & FSRU (new build) \\
\hline Jetty including piping & 80 & 80 \\
\hline Unloading lines & 100 & $\mathrm{~N} / \mathrm{A}$ \\
\hline Tanks 1x180,000 m3 & 180 & in FSRU \\
\hline FSRU Vessel & $\mathrm{N} / \mathrm{A}$ & 250 \\
\hline Process plant & 100 & in FSRU \\
\hline Utilities & 60 & in FSRU \\
\hline Onshore interface/infrastructure & $\mathrm{N} / \mathrm{A}$ & 30 \\
\hline CAPEX & $\mathbf{5 2 0}$ & $\mathbf{3 6 0}$ \\
\hline Contingency 30\% Onshore, 10\% FSRU & 156 & 36 \\
\hline Owners's Costs & 74 & 54 \\
\hline Total CAPEX & $\mathbf{7 5 0}$ & $\mathbf{4 5 0}$ \\
\hline
\end{tabular}

Source: By author

Regarding schedule, the time taken to construct an onshore terminal is driven by the construction of the tanks which is typically 36-40 months. New build FSRUs typically take 27-36 months but a conversion would be less at typically 18-24 months. However, the real schedule advantage is if a FSRU is readily available e.g. reassigned from another project or constructed on a speculative basis. A recent example of this is the second FSRU for Ain Sokhna which commenced operation in just 5 months ${ }^{30}$ after the issue of tender documents. Project schedules are discussed further in chapter 8.

The capital cost of an FSRU terminal comprises three major components:

- The FSRU vessel

- The infrastructure

- Owner's costs

\section{FSRU Vessel Cost}

\section{New Build}

The vessel can either be a new build or the conversion of an existing LNG tanker. A new build $173,000 \mathrm{~m}^{3} 6 \mathrm{mtpa}$ FSRU vessel would currently cost in the range of $\$ 240-280 \mathrm{~m}^{31,32}$. The cost of new

\footnotetext{
${ }^{30}$ http://www.bw-group.com/our-business/bw-Ing/bw-gas-solutions/record-fast-track-fsru-project-implementation-in-egypt 31 http://www.lexology.com/library/detail.aspx?g=964b07cd-2d16-420b-96d4-af47dc2935f2

${ }^{32}$ http://fairplay.ihs.com/commerce/article/4279031/h\%C3\%B6egh-Ing-signs-letter-of-intent-for-fsrus-to-pursue-expansionstrategy
} 

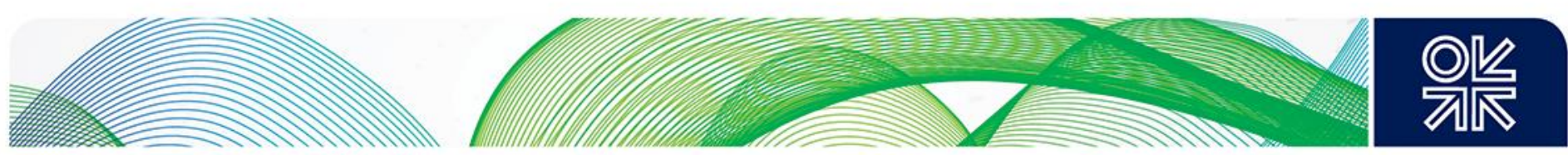

vessels has been dropping lately ${ }^{33}$ due to a high degree of competition between the 3 main Korean shipyards - DSME, Hyundai and Samsung and the low order book for new shipping generally e.g. container ships and bulk carriers. However, there is a view that costs will now rise due to increasing demand for vessels ${ }^{34}$. Table 6.2 summarises some recent FSRU construction contract values.

Table 6.2 Recent New Build FSRU Contract Values

\begin{tabular}{|l|c|r|r|r|r|r|c|}
\hline \multicolumn{1}{|c|}{ Vessel } & Owner & \multicolumn{1}{c|}{$\begin{array}{c}\text { Storage } \\
\mathbf{m}^{\mathbf{3}}\end{array}$} & $\begin{array}{c}\text { Send-out } \\
\mathbf{m t p a}\end{array}$ & $\begin{array}{c}\text { Send-out } \\
\mathbf{m m s c f d}\end{array}$ & Shipyard & Order Placed & $\begin{array}{c}\text { Order Value } \\
\mathbf{\$ m}\end{array}$ \\
\hline Giant (FSRU\#7) & Höegh & 170,000 & 6.2 & 750 & Hyundai & Jun-11 & 236 \\
\hline Gallant (FSRU\#8) & Höegh & 170,000 & 4.1 & 500 & Hyundai & Jun-11 & 250 \\
\hline Independence & Höegh & 170,000 & 3.2 & 384 & Hyundai & Jun-11 & 250 \\
\hline FSRU\#9 & Höegh & 170,000 & 8.3 & 1,000 & Hyundai & Jan-17 & 236 \\
\hline FSRU\#10 & Höegh & 170,000 & 8.3 & 1,000 & Samsung & Jan-17 & 270 \\
\hline Experience & Excelerate & 173,400 & 8.3 & 1,000 & DSME & Aug-11 & 280 \\
\hline
\end{tabular}

Source: By author

\section{Conversion}

The conversion of an existing LNG tanker is likely to cost about $£ 80 \mathrm{~m}^{35}$ plus the cost of purchasing the tanker. If a nearly new tanker is purchased at $\$ 150 \mathrm{~m}$ the final cost of $£ 230 \mathrm{~m}$ will be similar to a new build FSRU but has the advantage of being completed in 18 months compared to 36 months for a new build vessel. An older tanker would be cheaper and would bring the total cost down.

This cost covers the supply and installation of the regasification equipment - high pressure pumps, vaporisers, metering station, gas export arm(s) or hoses, additional utility systems needed to meet the increased electrical power demand and water circulation for vaporization plus any modifications for permanent mooring e.g. imported power, hull coatings to meet the harbour authority regulations. Conversions were very popular for the early FSRUs but have recently been dropped in favour of new build vessels. This was probably due to the demand for larger $173,000 \mathrm{~m}^{3}$ vessels while most existing LNG tankers were in the range of $130,000-140,000 \mathrm{~m}^{3}$. Höegh LNG recently announced that it would convert one of its existing LNG tankers ${ }^{36}$ as a faster option than a new built vessel to meet the demands of the 2017-2018 FSRU market.

\section{Infrastructure Cost}

\section{Inshore}

The shore-based infrastructure comprises the jetty structure for mooring the vessel, the transfer of LNG from the supply tanker and the piping systems necessary to connect the regasified LNG to the customer or gas network as shown typically in figures 6.1 and 6.2. The supply and construction of the infrastructure is normally managed by the port or energy company using local contractors. This can typically represent $\$ 50-100 \mathrm{~m}$ but considerably more if a new harbour or breakwater is required. If this cost is project specific then it will have to be paid for by the project and an example is the current Bahrain LNG project ${ }^{37}$. The exception to this may be if the harbour development or improvement is part of a larger national infrastructure development.

Figure 6.1 shows the jetty and moorings for the Klaipeda terminal in Lithuania located in the harbour. The gas is exported via an $18-\mathrm{km}$ pipeline to the gas network ${ }^{38}$. Figure 6.2 shows the GNL Escobar

\footnotetext{
${ }^{33}$ http://fairplay.ihs.com/commerce/article/4279031/h\%C3\%B6egh-Ing-signs-letter-of-intent-for-fsrus-to-pursue-expansionstrategy

${ }^{34}$ http://gasprocessingnews.com/news/fsru-ships-in-high-demand-as-buyers-seek-quicker-route-to-Ing.aspx

35 http://www.poten.com/wp-content/uploads/2015/06/LNG-Opinion-Floating-Regas.pdf

36 http://www.lexology.com/library/detail.aspx?g=964b07cd-2d16-420b-96d4-af47dc2935f2

$37 \mathrm{http}: / /$ www.Ingworldnews.com/bahrain-Ing-terminal-construction-to-start-in-january/
} 

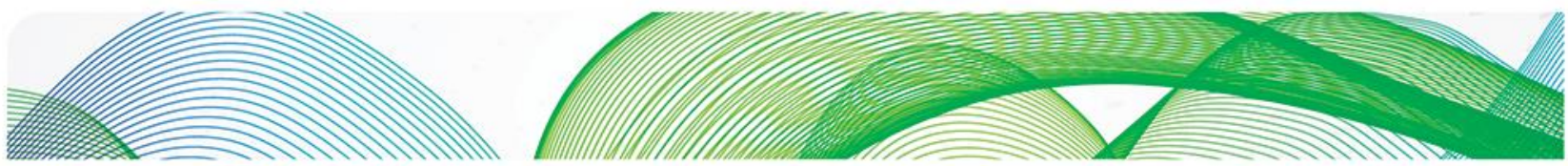

\section{OR/}

arrangement located shore-side with an above ground jetty transfer line connecting to the $40 \mathrm{~km} \times 30$ " pipeline to the gas network. The cost of this infrastructure was high at $\$ 140-150 \mathrm{~m}^{39}$ probably reflecting the long pipeline to the gas grid and dredging $\operatorname{costs}^{40}$.

It must be noted that the cost of inshore infrastructure is totally location-specific and very dependent on the existing harbour facilities and the length of the pipeline required to connect to the customer or gas network. Onshore pipelines would be 24-30" diameter and typically cost $\$ 2-3 \mathrm{~m}$ per km¹.

\section{Figure 6.1 Klaipeda FSRU Terminal Showing Jetty and Moorings}

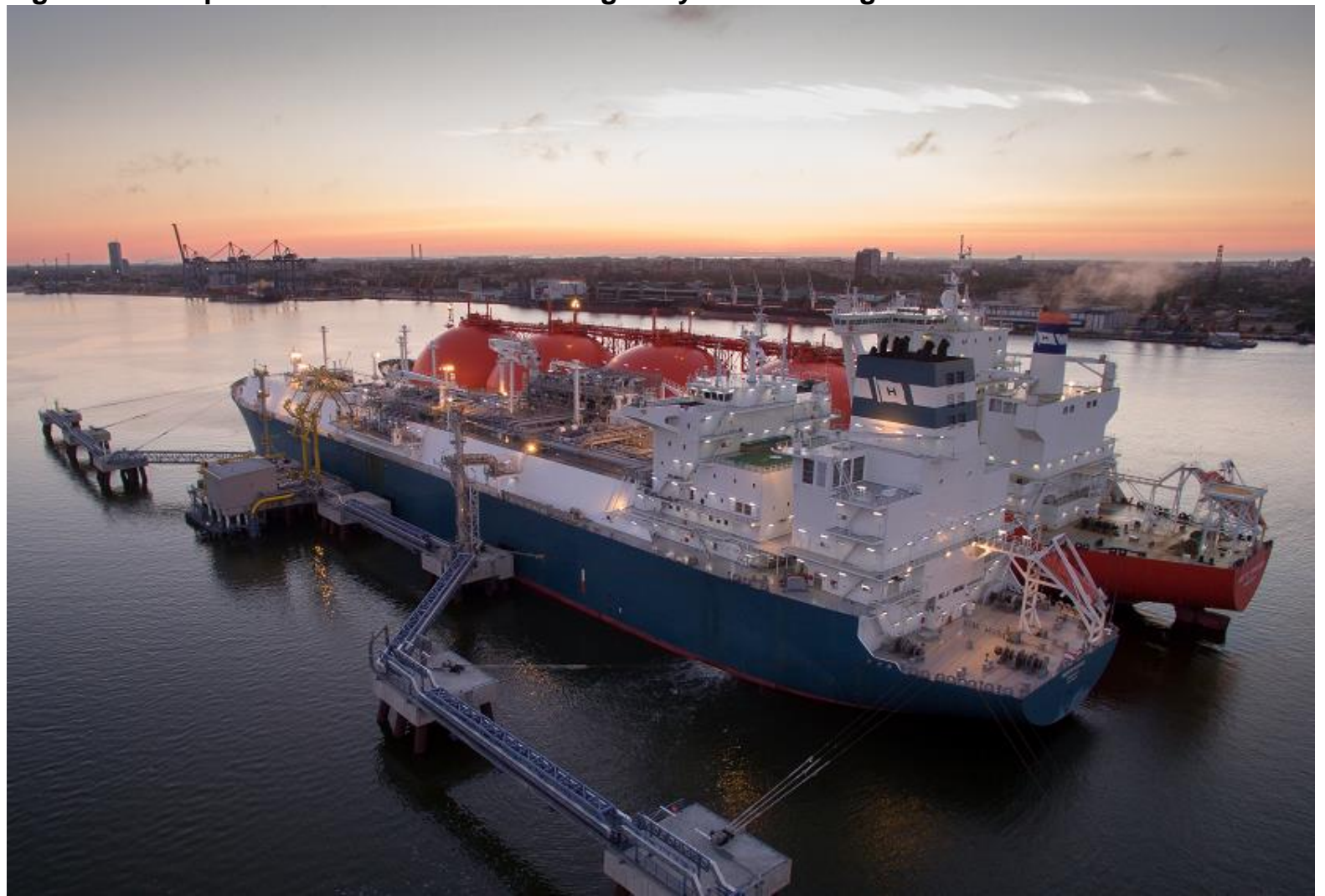

Source: Courtesy Höegh LNG

\footnotetext{
${ }^{38} \mathrm{http}: / /$ www.hydrocarbons-technology.com/projects/klaipda-Ing-terminal/

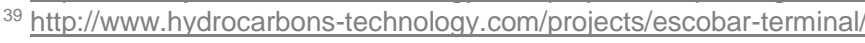

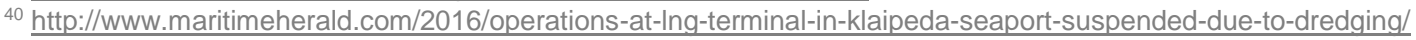

${ }^{41}$ Author's data
} 

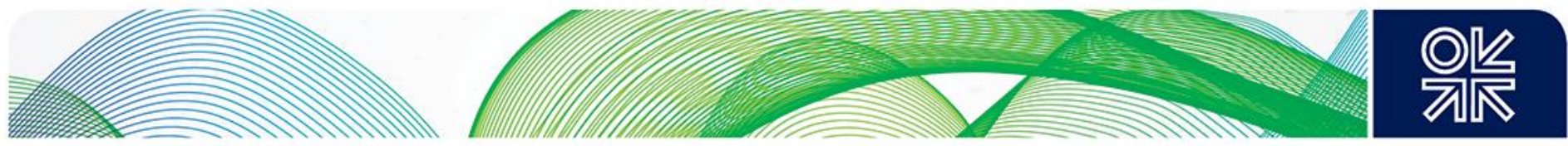

Figure 6.2 GNL Escobar Terminal Argentina

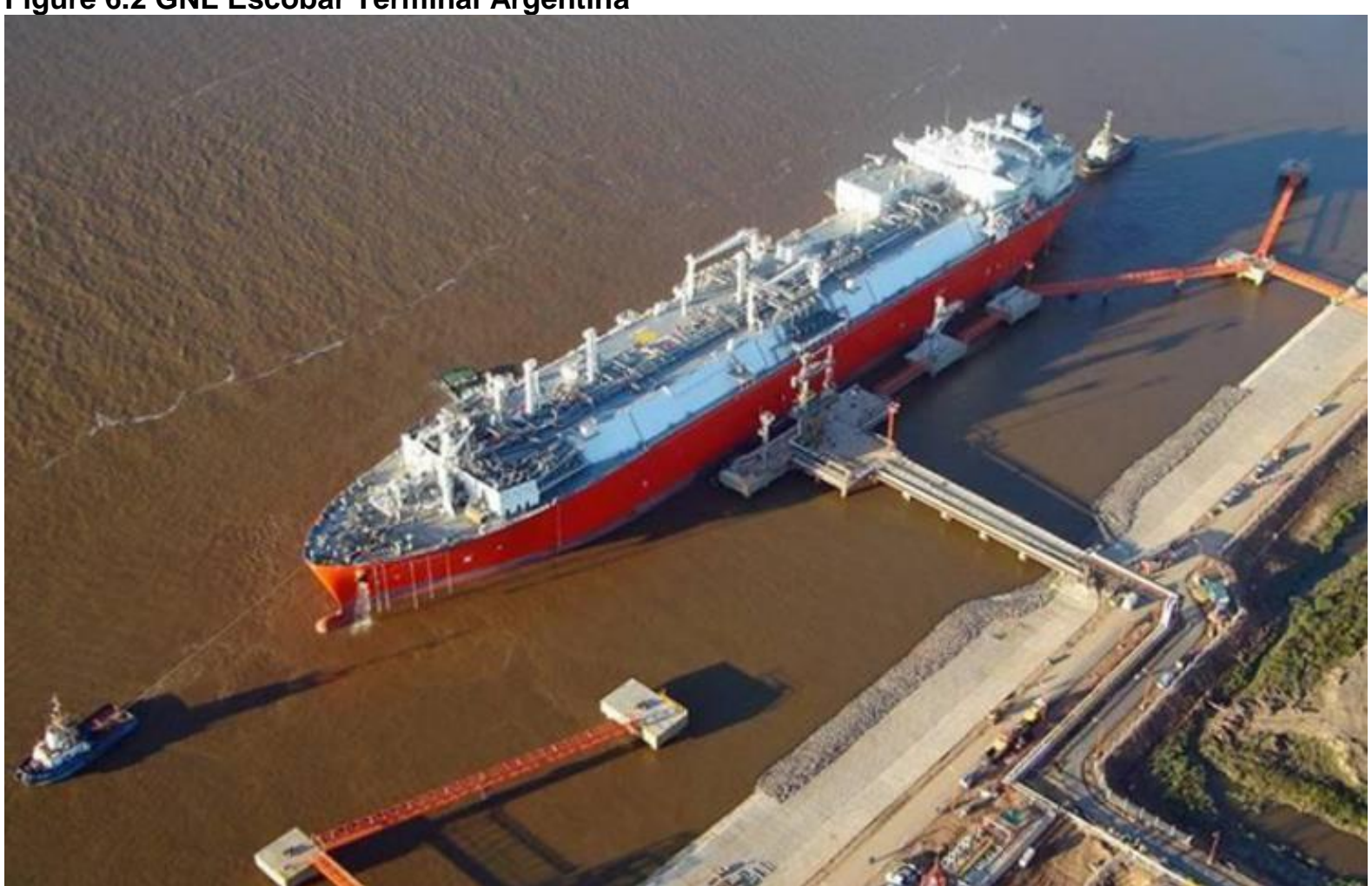

Source: Courtesy Excelerate Energy

\section{Offshore}

For an offshore (open water) terminal the vessel would be moored and connected to the gas export system using either a submerged buoy system as shown in figure 6.3 or a surface system as shown in figure 6.4. The submerged turret is usually based on the STL turret mooring and transfer system designed by Advanced Production Loading (APL) of Norway ${ }^{42}$. The single point mooring (SPM) surface turret used at the Lampung, Indonesia terminal was designed, constructed, and fabricated by SOFEC. It is connected to shore by a $20 \mathrm{~km}$ pipeline.

It must be noted that the cost of the offshore infrastructure is totally location specific and very dependent on the length of the offshore and onshore pipeline required to connect to the customer or gas network. Subsea export gas pipelines are typically 24-30" diameter and would cost of the order of $\$ 3-4 \mathrm{~m}$ per $\mathrm{km}^{43}$. Onshore pipelines would typically cost $\$ 2-3 \mathrm{~m}$ per $\mathrm{km}$.

\footnotetext{
${ }^{42}$ https://www.nov.com/Segments/Completion and Production Solutions/Floating Production Systems/APL Mooring and Lo ading Systems/Submerged Turret Loading.aspx

${ }^{43}$ Author's data
} 

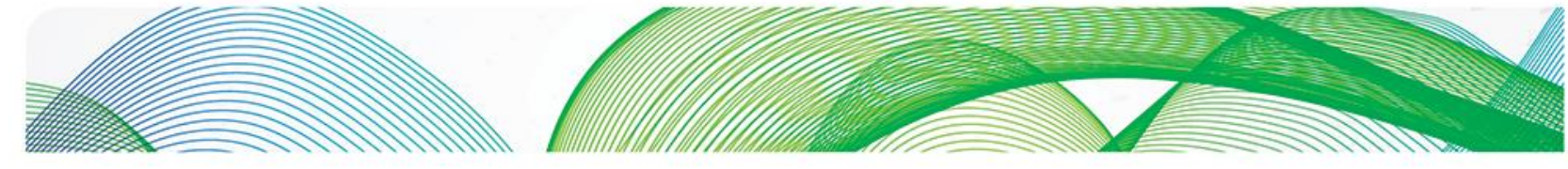

\section{勾}

\section{Figure 6.3 Submerged Turret}

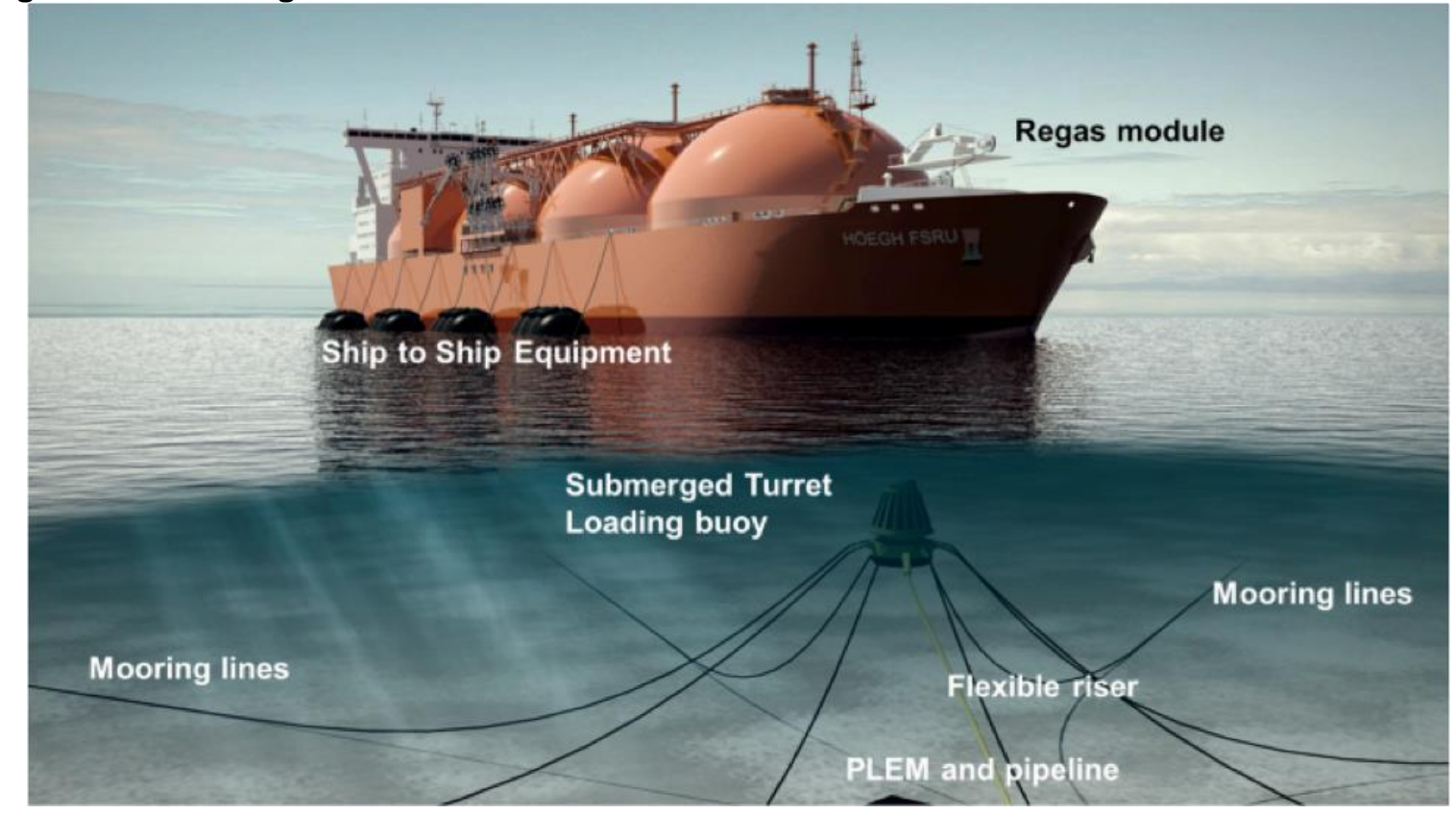

Source: Courtesy Höegh LNG

\section{Figure 6.4 Surface Turret - Lampung, Indonesia}

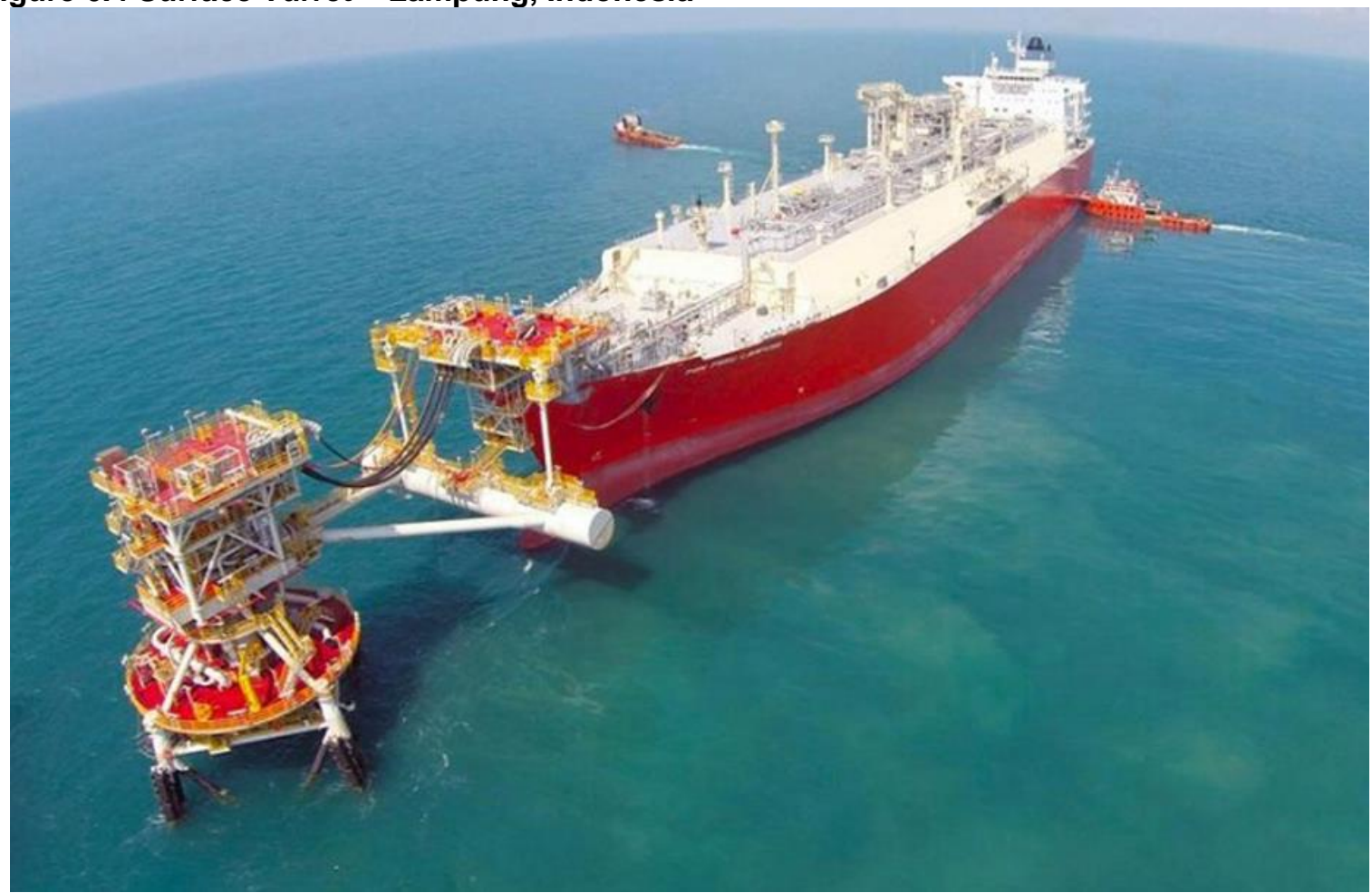

Source: Courtesy Höegh LNG 

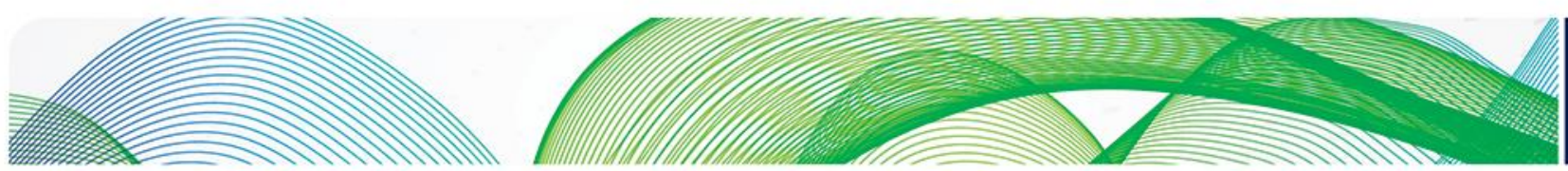

\section{O败}

\section{Owner's Costs}

These typically include the costs of the owner's project team and support services to oversee all aspects of the project both technically and commercially from project commencement to handover to the operations department.

They include the cost of all specialist contractors and consultants used during the period prior to the Final Investment Decision (FID) e.g. feasibility studies, conceptual design, and environmental impact assessment. They also include the preparation of contracts e.g. project scope and procurement, LNG supply and gas sales contracts as well as working with project financiers, government and other permitting bodies. 

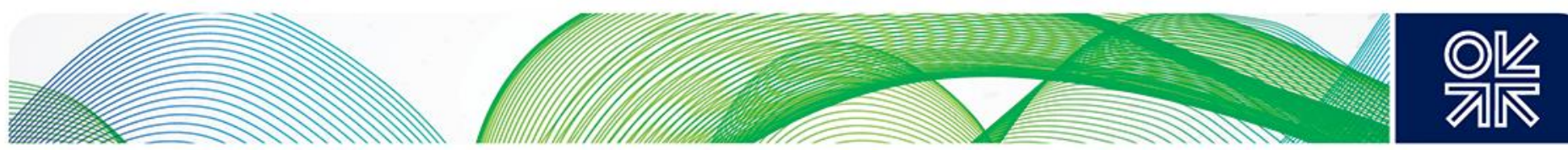

\section{Chapter 7. Operating Costs}

\section{Scope}

Operating costs are likely to cover the following:

- Provision of personnel - onboard and located on the onshore interface

- Ongoing head office support to operations

- Fuel gas and oil for power generation and steam generation

- Maintenance and inspection

- Spare parts

- Chemicals and lubricants

- Insurance

- Harbour fees

- Tugs for supply tanker manoeuvering

- Service boats for offshore located FSRUs

- Dredging

- Financing costs

Personnel on board the FSRU and those at the onshore interface will work on a shift pattern. For offshore located FSRUs the personnel will likely operate on a typical offshore rotation. The FSRU manning is typically 20-28 personnel plus 4 located at the onshore interface. FSRUs classified as ships will require a full marine crew of typically 27 seafarers. FSRUs classified as offshore installations will probably only require 20 personnel. More crew information is available in a paper by Poten \& Partners ${ }^{44}$. This cost component will include all personnel provisions and catering as well as transportation.

There will be ongoing head office support to operations and technical assistance.

BOG will be used as fuel gas supplemented as required by vaporising LNG. This usage is effectively a loss of LNG or shrinkage between the LNG supplied to the FSRU and the LNG (gas) exported and can be charged either at the LNG supply cost or the gas sales cost, depending on the accounting method agreed between the parties. Fuel oil for black starting will be supplied by bunkers.

Maintenance and inspection covers the routine tasks plus inspections if required. If the vessel is classed as an offshore installation it is unlikely that it will require dry dock inspection during its contract period and underwater inspections will be undertaken. If the vessel is classified as a ship then dry docking may be required. This is dependent on the class of the particular vessel.

Spare parts costs covers the provision of ongoing spares for maintenance. This is the same for chemicals and lubricants required for ongoing operation and maintenance.

Insurance of the vessel will be covered by the vessel owner and include $3^{\text {rd }}$ party liabilities.

Harbour fees will cover the operation of the FSRU, and will also be payable for the supply tankers and tugs for handling. The cost of the tugs will likely be paid by the LNG supply company but this will depend on the terms agreed between the parties. 

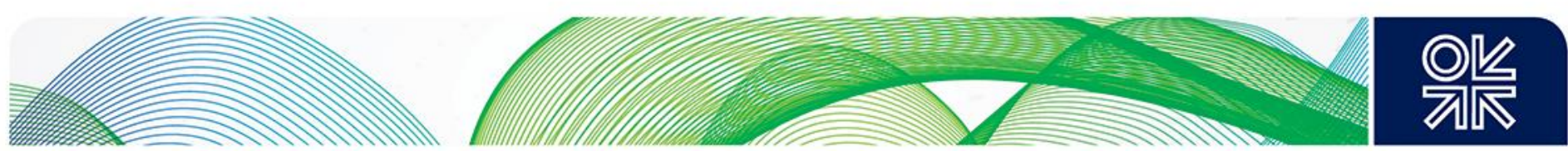

Service boats will be required for FSRUs located offshore and those inshore not connected by jetty or bridge to shore.

Dredging to maintain a suitable draft for the vessels can be a major operating cost. This is an issue for the Lithuanian terminal and reportedly led to a shutdown of the terminal in $2016^{45}$.

For FSRUs contracted on an overall leasing rate the financing costs are normally included in that rate. It would be a separate cost item for FSRUs owned outright by the terminal operator and purchased with a loan.

\section{Costs}

Operating costs are generally estimated at $2.5 \%$ of CAPEX per year. Assuming a CAPEX of $\$ 350 \mathrm{~m}$ $(\$ 275 \mathrm{~m}$ for FSRU $+\$ 75 \mathrm{~m}$ for the infrastructure) this would estimate the OPEX at $\$ 8.75 \mathrm{~m} / \mathrm{y}$ i.e. $\$ 24,000 /$ day. This aligns well with the recent publication by QED Consulting ${ }^{46}$ which provides estimates based on the financial reports of the vessel owners. Other sources quote OPEX in the range of $\$ 20-45,000 /$ day.

The actual $\$$ /day figure will be very dependent on the location, the configuration i.e. offshore or inshore and the capacity of the vessel.

This cost excludes the consumption of LNG to generate heat and power for the regasification process. As discussed in chapter 4, for a send-out rate of $5 \mathrm{mtpa}$ this consumption is $6.2 \mathrm{t} / \mathrm{h}(150 \mathrm{t} / \mathrm{d})$ for open loop and $14.8 \mathrm{t} / \mathrm{h}(335 \mathrm{t} / \mathrm{d})$ for closed loop. Using an LNG price of $\$ 10 / \mathrm{mmbtu}(\$ 500 / \mathrm{t})$ this adds $\$ 72,000 / \mathrm{d}$ and $\$ 167,000 / \mathrm{d}$ respectively to the operating costs. The cost is directly proportional to the send out rate except for the small $0.5 \mathrm{t} / \mathrm{h}(12 \mathrm{t} / \mathrm{d})$ for general vessel use. This consumption is generally accounted for as shrinkage i.e. the difference between LNG supplied to the FSRU and that exported as sales gas.

\footnotetext{
${ }^{45} \mathrm{http}: / /$ www.maritimeherald.com/2016/operations-at-Ing-terminal-in-klaipeda-seaport-suspended-due-to-dredging/

${ }^{46}$ http://pdf.usaid.gov/pdf docs/PA00KWB5.pdf
} 

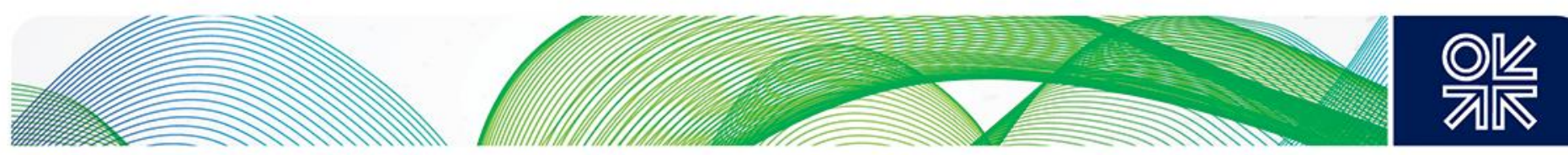

\section{Chapter 8. Project Schedules}

FSRU project schedules are driven primarily by 3 key activities:

- Preliminary discussions \& feasibility studies

- Permitting \& pre-engineering to achieve project approval

- Construction

\section{Preliminary Discussions \& Feasibility Studies}

These cover the initial discussions and negotiations between the various stakeholders - the gas customer, the LNG supplier(s), the possible FSRU provider, the local authorities including the harbour authority and project financing. The purpose of these discussions is to determine if the project is feasible and usually concludes with the issue of a feasibility report with next stage actions. This stage will include preliminary conceptual design work to ensure the technical feasibility. This can be a lengthy process for a first project but is likely to be much shorter for an expansion i.e. a second FSRU. An excellent example of a scope of work for a feasibility study is presented in the Bangladesh Power Cell Terms of Reference ${ }^{47}$.

\section{Permitting \& Pre-Engineering to Achieve Project Approval (FID)}

This stage covers the preparation of the contracts between the stakeholders, the development of the concept, specifying the precise project location, obtaining the necessary permits and determining the project budget and schedules as the basis for project approval (Final Investment Decision). It will include discussions with the necessary permitting authorities to ensure all the required permits can be issued for construction and subsequent operation. This is critical for making the final investment decision. As for the preliminary phase this can be a lengthy process for a first project but is likely to be much shorter for an expansion i.e. a second FSRU.

\section{Construction}

This covers the time taken to obtain the FSRU vessel and construct the infrastructure e.g. jetty and interconnecting gas pipeline. The two activities are independent and can run in parallel. Project schedules have ranged from just 5 months to $2-3$ years.

The schedule to obtain the FSRU will depend on whether the vessel is readily available, either released from another project or a new vessel about to be delivered from the shipyard. The new build option could also be a completely new build vessel or the conversion of an existing LNG tanker.

With 26 FSRUs now in the fleet, vessels are becoming available as FSRU terminals are shut down. An example is the Golar Spirit ${ }^{48}$ which is currently located at Pecem, Brazil but Petrobras appears to be terminating the contract early ${ }^{49}$. Golar LNG is actively looking at new terminal projects for the vessel.

If no suitable existing vessel is available several new build vessels are currently under construction for delivery in 2018. Construction schedules for FSRUs are very similar to LNG tankers i.e. 27-36 months as shown in table 8.1. The delivery time is very dependent on market conditions and the shipyard slots available.

\footnotetext{
${ }^{47}$ http://powercell.portal.gov.bd/sites/default/files/files/powercell.portal.gov.bd/page/2008941d d13e 4f3e a934 615cfcd6f121/ TOR\%20for\%20Financial\%20Advisory.pdf THIS LINK DIDN'T WORK FOR ME.

${ }^{48} \mathrm{http} / / / \mathrm{www}$.offshoreenergytoday.com/petrobras-ends-golars-fsru-contract/

${ }^{49} \mathrm{http}$ ://www.offshoreenergytoday.com/petrobras-ends-golars-fsru-contract/
} 

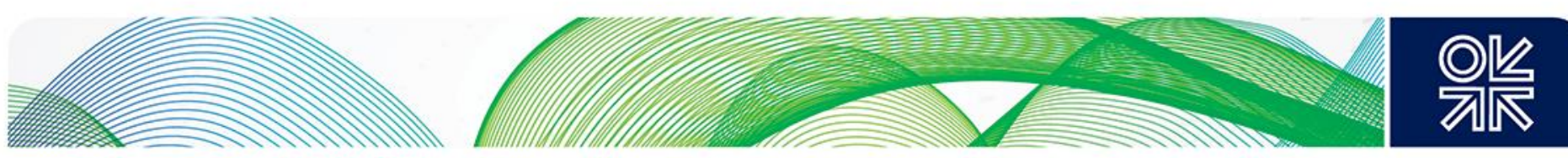

A conversion can be undertaken in a shorter time of 18 months but this can be reduced to just 12 months if the long lead equipment is ordered earlier. Höegh recently placed an order ${ }^{50}$ with Wärtsilä and Moss Maritime for long lead delivery items to reduce the conversion schedule from 18 to just 12 months.

Table 8.1 FSRU Construction Schedules

\begin{tabular}{|l|c|c|c|c|c|}
\hline Vessel & Owner & Shipyard & Ordered & Delivered & Months \\
\hline Gallant & Höegh & Hyundai & Jun-11 & Jun-14 & 36 \\
\hline Independence & Höegh & Hyundai & Jun-11 & May-14 & 35 \\
\hline PGN Lampung & Höegh & Hyundai & Jun-11 & Apr-14 & 33 \\
\hline FSRU\#10 & Höegh & Samsung & Jan-17 & May-19 & 28 \\
\hline Experience & Excelerate & DSME & Aug-11 & May-14 & 33 \\
\hline Eskimo & Golar & Samsung & Mar-12 & Dec-14 & 33 \\
\hline Igloo & Golar & Samsung & Aug-11 & Dec-13 & 27 \\
\hline Singapore & BW Gas & Samsung & Jan-13 & Sep-15 & 32 \\
\hline
\end{tabular}

Source: By author, Published Data

\section{Example Project Schedules}

Figure 8.1 shows typical project schedules for projects undertaken by Excelerate Energy. These range from just 10 months to 42 months. The time taken for permitting is highly variable and dependent on the local authorities.

Figure 8.1 Project Schedules in Months

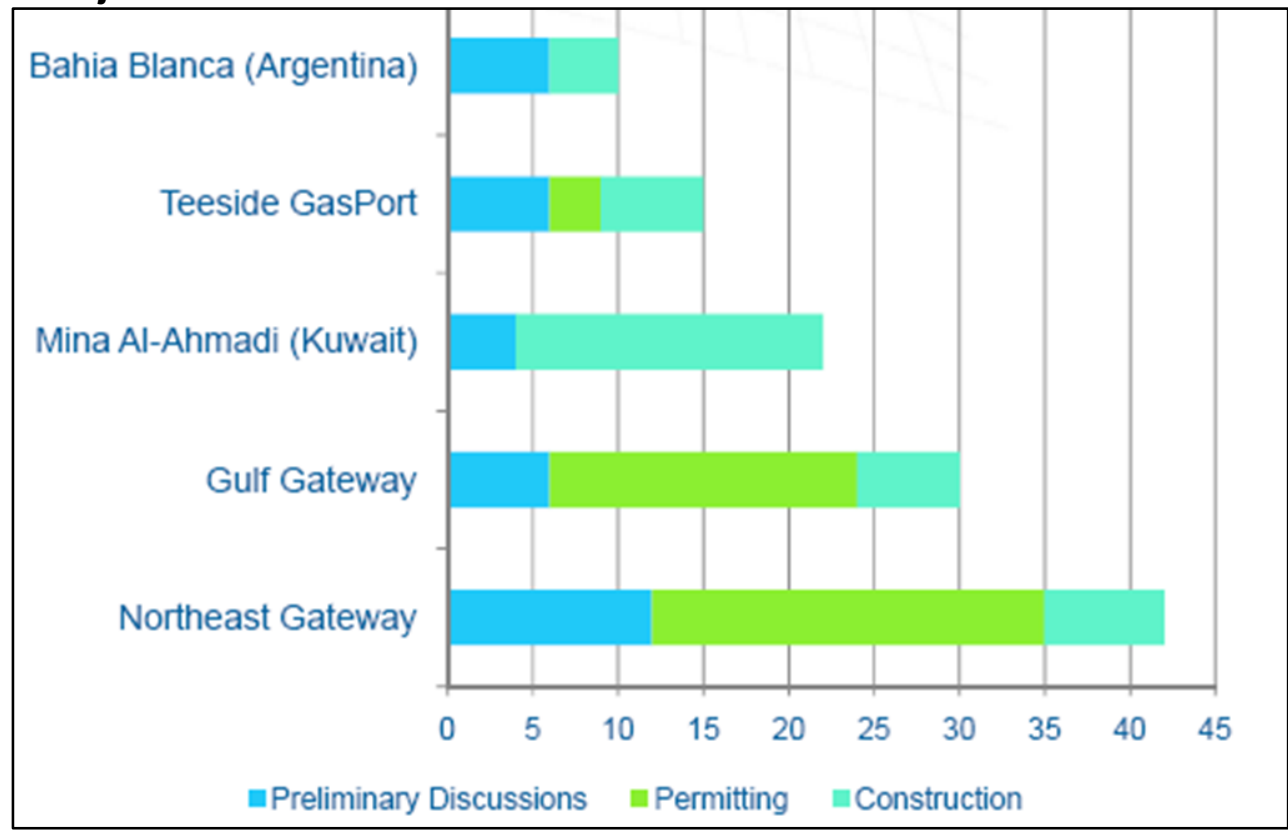

Source: Courtesy Excelerate Energy

\footnotetext{
${ }^{50}$ http://www.Ingworldnews.com/hoegh-Ing-in-first-fsru-conversion-project/
} 

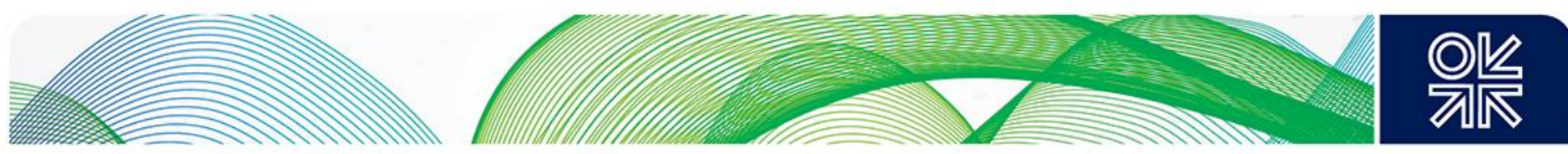

Table 8.2 summarises the key events for the recent fast track Ain Sokhna $2^{\text {nd }}$ FRSU terminal which was completed in just 5 months. This was helped by the BW Singapore vessel being readily available and the required jetty infrastructure including LNG unloading systems were already in place. If a new jetty facility including loading arms had been required then 5 months would not be possible. The fact it was an expansion probably meant that the necessary relationships were in place between the stakeholders to conclude the agreements quickly.

Table 8.2 BW Gas - Fast track project - First gas in just 5 months

\begin{tabular}{|c|c|l|}
\hline $\mathbf{2 0 1 5}$ & Month & Key Event \\
\hline May & 0 & EGAS issues invitation to tender \\
\hline June & 1 & BW Gas submits bid \\
\hline July & 2 & BW awarded project \\
\hline August & 3 & Agreement signed \\
\hline September & 4 & FSRU delivered (note existing jetty used) \\
\hline October & 5 & First cargo received for cool down \\
\hline $1^{\text {st }}$ November & 5 & First gas delivered \\
\hline
\end{tabular}

Source: Courtesy BW Gas 

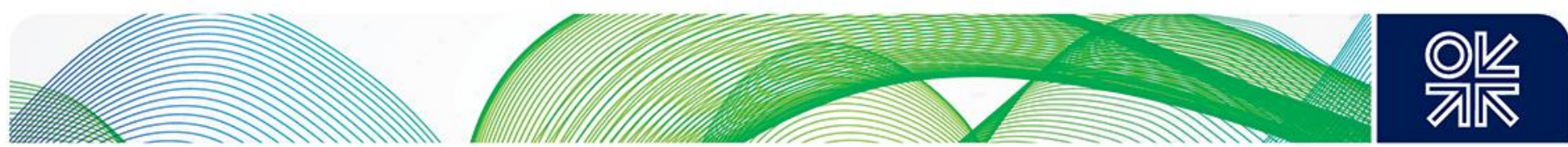

\section{Chapter 9. Commercial Considerations}

\section{Business Models}

LNG Import terminal business models normally take the form of Integrated, Merchant or Tolling arrangements which have evolved as shown in figure 9.1. FSRUs are functionally identical to onshore terminals and can use any of these models. The tolling model seems to be the most popular as it provides a simple arrangement directly with the energy company and the leasing option fits well with shorter term contracts.

The integrated model was the original approach used for dedicated onshore terminals. The terminal is owned by the energy company which also owns the source gas, liquefies it, ships it, stores and vaporises it and transports the natural gas to a grid tie-in point or directly to a consumer e.g. power station. The design, construction and installation of the terminal is undertaken by a contractor usually on an EPC basis. The Gazprom Kaliningrad FSRU will most likely follow this model with Gazprom owning and operating the whole value train - source gas, liquefaction, shipping and regasification.

The merchant approach is more complicated. The terminal is owned by the party or parties who purchase and take title of the LNG and then sell the regasified LNG (natural gas) to buyers. The owners of the source gas, who typically produce the LNG, are not a party to the terminal model - they just sell the LNG to the 'merchant'. The merchant makes its profit from the difference between the LNG purchase price and the gas sales price. Several FSRU owners have looked at this approach, where they would become LNG traders - this being quite a departure from their normal business model of just owning and operating the FSRU. However it appears they are focusing their resources on the rapidly expanding vessel ownership and operation part of the business.

With a tolling arrangement the terminal owner rents capacity to the energy company e.g. the LNG supplier or the gas buyer at an inclusive rate as discussed earlier in this chapter. As stated above this appears to be the preferred approach for FSRU based terminals.

\section{Figure 9.1 Business Models}

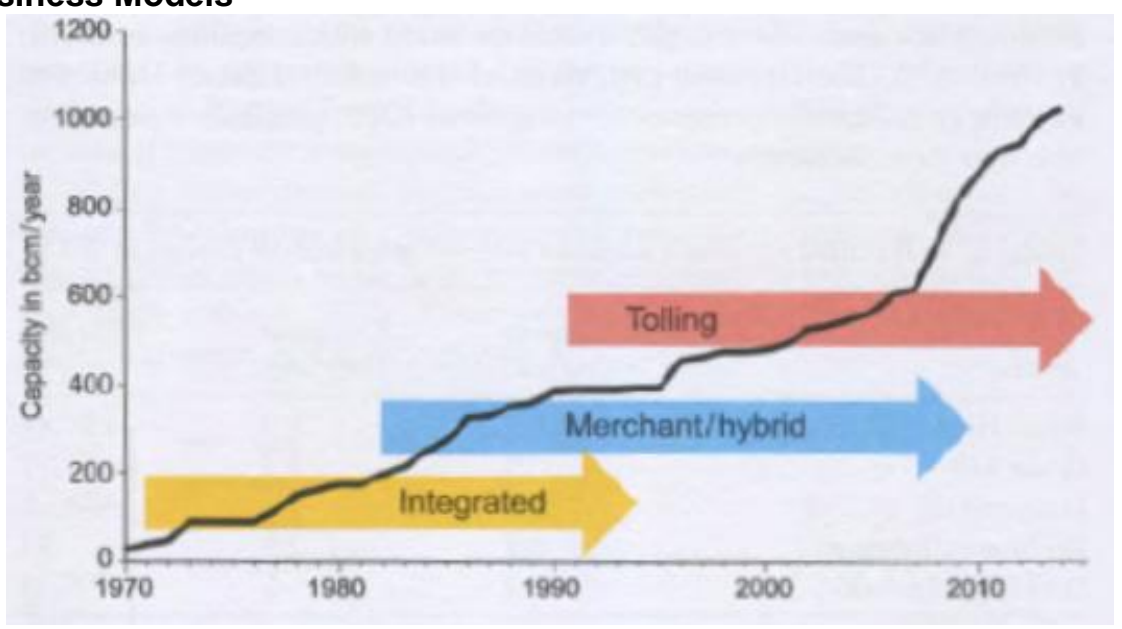

Source: LNG Markets in Transition ${ }^{51}$, chart by Chis Le Fevre

\section{Contract Models}

The simplest form is a leasing or tolling contract between the FSRU service provider and the energy company. The service provider supplies the vessel for the agreed contract period and operates it if required. In the simplest form the infrastructure to moor the FSRU and export the gas by pipeline to 

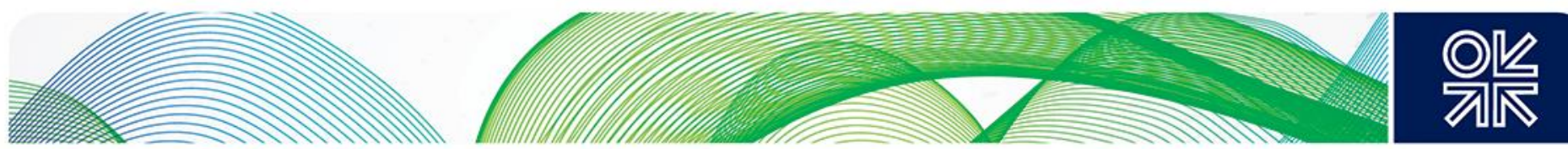

the customer is contracted directly between the energy company and the other parties. The energy company procures the LNG, which is delivered by supply tanker. An example of this type of contract is the one between Excelerate Energy and the Puerto Rico Electric Power Authority for the Aguirre Terminal52, which provides a good description of the various contract terms required.

A more detailed example of the relationship between the various stakeholders is shown in a Navigant presentation ${ }^{53}$ for the recently completed Aqaba FSRU terminal in Jordan where NEPCO is the gas supplier.

Figure 9.2 shows the principal parties and their scope of supply to the project. Figure 9.3 shows the commercial relationships, contracts and the guarantees between these parties. Navigant stress in their presentation the importance of the following for a successful project:

- Setting clear project objectives that are consistent across the project

- Clearly defining the project interfaces and scopes of supply

- Identifying financially credible gas off-takers

- Buyers need to demonstrate sustainable credit worthiness to get competitive prices

- Project developers will price in credit risk making offers expensive

Figure 9.2 Contract Structure and Credit Support Mechanisms

The commercial structure: NEPCO, a Government owned company, will mange and operate the LNG project

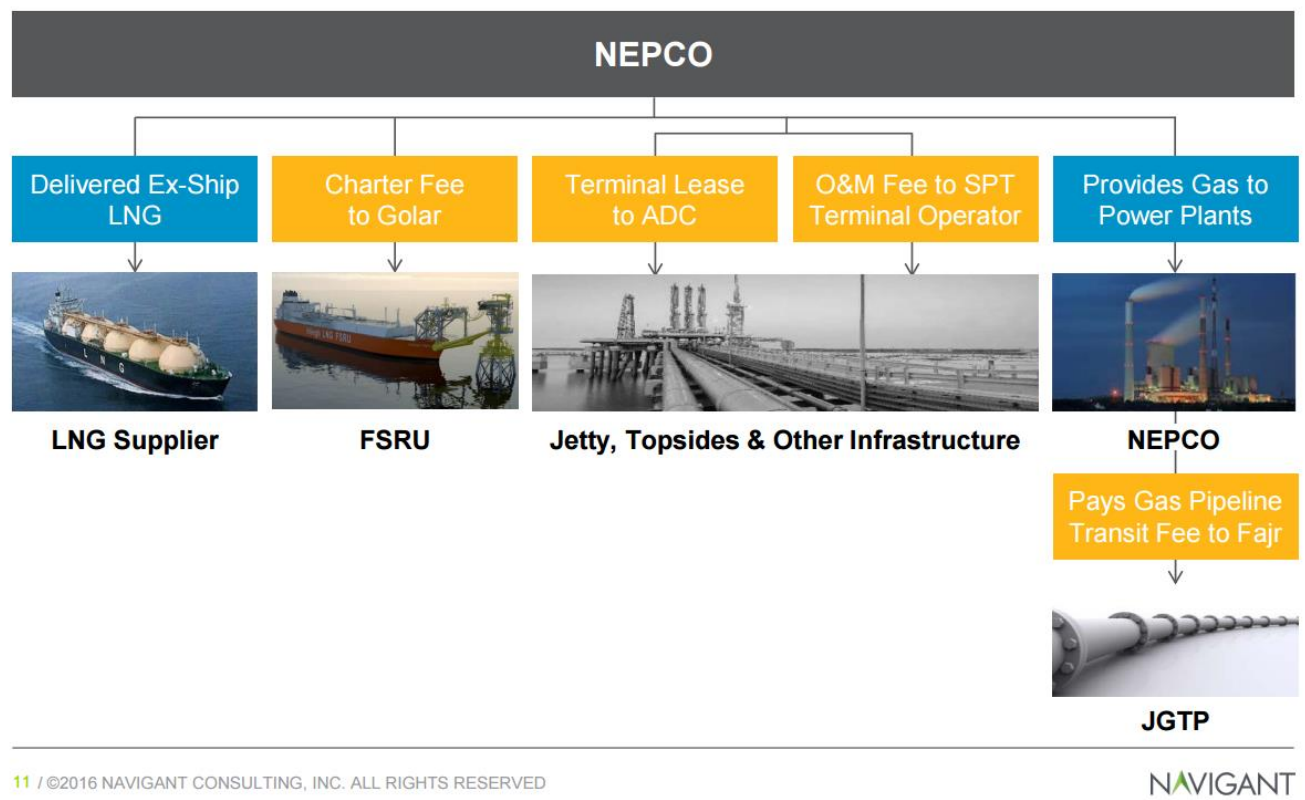

Source: Navigant

52 https://www2.aeepr.com/Documentos/Ley57/CONTRATOS\%20GENERAL/2014-03-

17\%20Time\%20Charter\%20Party\%20and\%20LNG\%20Storage\%20and\%20Regasification\%20Agreement\%20(wo\%20schedul es).pdf

${ }^{53}$ http://www.theenergyexchange.co.uk/wp-content/uploads/2016/02/Richard-Bass-Navigant.pdf 

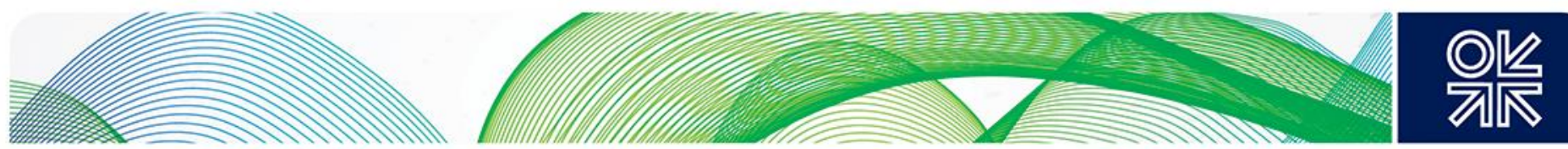

\section{Figure 9.3 Contract Structure and Credit Support Mechanisms}

\section{The contract structure and credit support mechanisms}

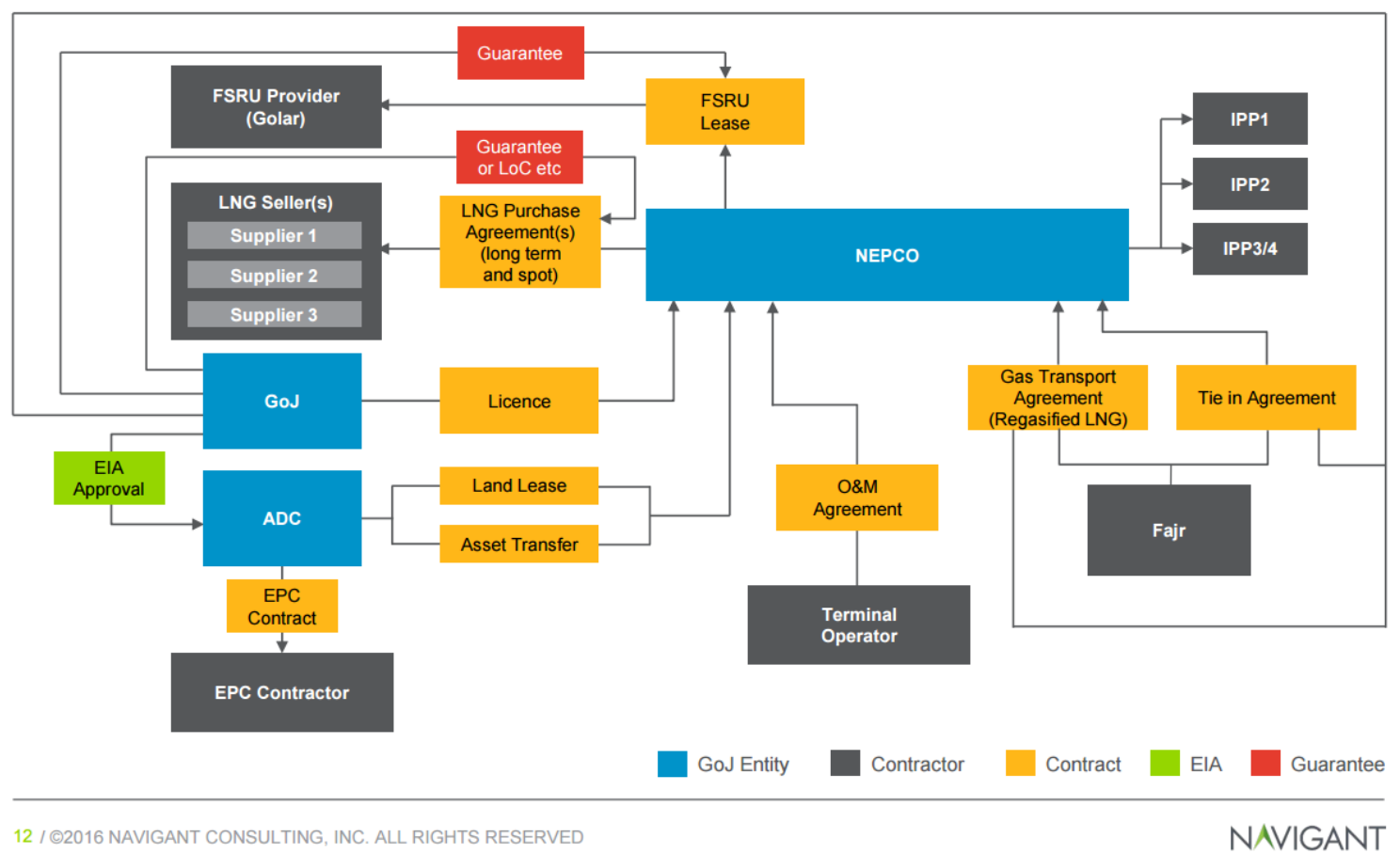

Source: Navigant

\section{Contract Periods (Leasing Periods)}

The first FSRUs were typically leased on a 10-15 year basis. This gave the owner some reassurance of recovering the capital cost of the vessel and finance charges over the lease period. Analysis of the early FSRUs would indicate that 10 years was the minimum lease period and the day rate was calculated on the basis of recovering the capital costs and finance costs over 8 years with the remaining 2 years as profit.

The range of lease periods now spans 5-20 years and is really driven by the gas market demand period. Most recently Egypt required a second FSRU on a short lease to meet a demand peak and EGas signed a 5-year lease with BW Gas for the Singapore FSRU. Also the project was executed in a record period of just 5 months showing how FSRUs offer great flexibility - an onshore terminal would have taken 4-5 years to construct, is there for life and is a sunk cost. The lease of Golar Arctic FSU for just 2 years ${ }^{54}$ to provide storage in Kingston harbour is exceptionally short. It is understood this vessel is essentially operating as an LNG tanker offloading smaller cargoes on to barges for transportation to the onshore regasification facilities.

Table 9.1 lists some of the contract leasing durations that have been published. It is interesting to note that obtaining leasing day rate figures is difficult due to their confidential commercial nature but lease durations are more available. This may in part be due to the wish by the FSRU providers to advertise when their vessels are likely to become available for another terminal project - a win-win situation. In the column stating the contract term the ' + ' refers to possible extensions 

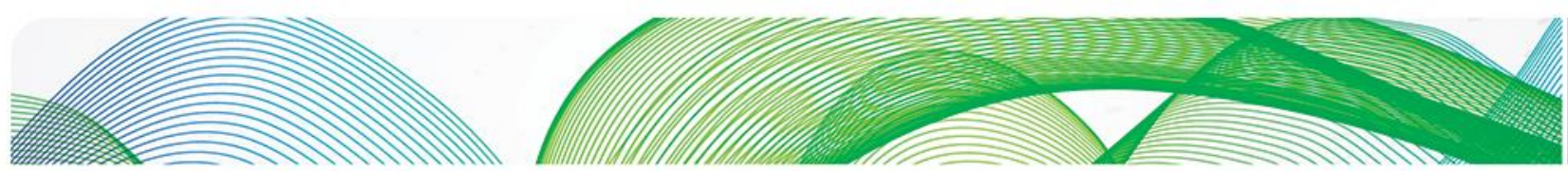

Table 9.1 Lease Contract Duration Examples

\begin{tabular}{|c|c|c|c|c|c|c|}
\hline Owner & Vessel Name & Terminal Name & Location & Status & Charter Company & $\begin{array}{c}\begin{array}{c}\text { Contract } \\
\text { term years }\end{array} \\
\end{array}$ \\
\hline \multirow{4}{*}{ Excelerate Energy } & Explorer & Mina Al-Ahmadi & Kuwait & Closed & KNPC & 5 \\
\hline & Experience & Guanabar Bay & Brazil & Operating & Petrobras & 15 \\
\hline & $\begin{array}{l}\text { Various } \\
\text { (GasPort) }\end{array}$ & Aguirre & Puerto Rico & Permitting & PREPA & $15+5$ \\
\hline & Excelerate & Ruwais & Abu Dhabi & Operating & GASCO & Long term \\
\hline \multirow{9}{*}{ Golar LNG } & Golar Spirit & Pecem & Brazil & Closed & Petrobras & $15+5$ \\
\hline & Golar Winter & Rio de Jeneiro & Brazil & Retired & Petrobras & 15 \\
\hline & Golar Winter & Bahia, Salvador & Brazil & Operating & Petrobras & 15 \\
\hline & Golar Freeze & Jebel Ali & Dubai & Operating & $\begin{array}{l}\text { Dubai Supply } \\
\text { Authority }\end{array}$ & 10 \\
\hline & $\begin{array}{c}\text { Nusantara Regas } \\
\text { Satu }\end{array}$ & Jakarta Bay & Indonesia & Operating & PTNR & 11 \\
\hline & Golar Igloo & Mina Al Ahmadi Port & Kuwait & Operating & KNPC & 5 \\
\hline & Golar Eskimo & Aqaba & Jordan & Operating & $\begin{array}{l}\text { Hashemite K of } \\
\text { Jordan }\end{array}$ & 5 \\
\hline & Golar Arctic & Kingston & Jamaica & $\begin{array}{c}\text { On site - but yet yet } \\
\text { operating }\end{array}$ & New Fortress Energy & 2 \\
\hline & Golar Tundra & Tema & Ghana & $\begin{array}{c}\text { On site - but yet yet } \\
\text { operating }\end{array}$ & $\begin{array}{l}\text { West Africa Gas } \\
\text { Limited }\end{array}$ & 5 \\
\hline \multirow{6}{*}{ Hoegh LNG } & Grace & Cartagena & Colombia & Operating & SPEC & 20 \\
\hline & Gallant & Ain Sokhna & Egypt & Operating & EGAS & 5 \\
\hline & Independence & Klaipeda & Lithuania & Operating & Klaipedos Nafta & 10 \\
\hline & PGN Lampung & Lampung, Sumatra & Indonesia & Operating & PGN LNG & 20 \\
\hline & GdF Suez Cape Anne & Tianjin & China & Operating & Engie & 5 \\
\hline & FSRU\#9 & Port Qasim 3 & Pakistan & Under Construction & GEIL & $20+5+5$ \\
\hline MOL & GNL Del Plata & Punta de Sayago & Uruguay & Under Construction & Gas Sayago & 20 \\
\hline \multirow{2}{*}{ BW Offshore } & BW Singapore & Ain Sokhna & Egypt & Being Converted & EGAS & 5 \\
\hline & TBA & Port Qasim 2 & Pakistan & Conversion Tanker & EGAS & 15 \\
\hline Teekay LNG & Bahrain LNG & Bahrain FSU & Bahrain & Under Construction & Bahrain LNG (JV) & 20 \\
\hline Bumi Armada & $\begin{array}{c}\text { Armada LNG } \\
\text { Mediterrana }\end{array}$ & Marsaxlokk Bay FSU & Malta & Being Converted & Electrogas Malta & 18 \\
\hline
\end{tabular}

Source: By author (please note this is not a complete list of FSRU vessels under contract and only included as indicative of typical durations)

\section{Leasing Charges}

The main difference between FSRUs and onshore terminals is that FSRUs are normally leased rather than purchased. Leasing is normally on a day rate basis which is calculated on the basis of recovering the capital cost of the vessel, the loan interest payments (finance charges) and the vessel owner's costs. It is also based in part on the duration of the lease period even if there will be a residual value at the end of the lease. Also a longer lease provides a more secure income for a longer period. 

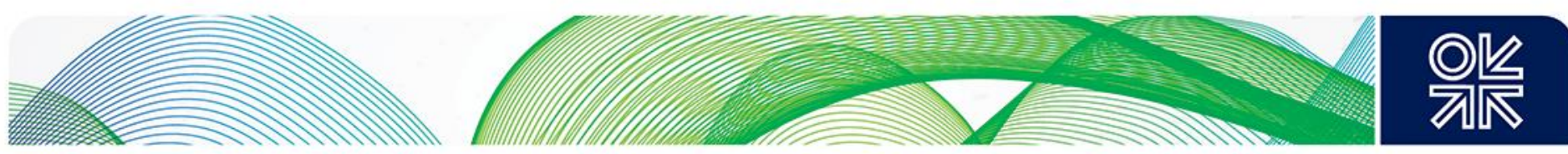

Leasing rates are typically in the range $\$ 110-160,000 /$ day and a recent publication by QED Consulting ${ }^{55}$ provides some estimates based on the financial reports of the vessel owners. Operating costs (OPEX) must be added and are typically in the range of $\$ 20-45,000 /$ day giving a total cost of $\$ 130-205,000 /$ day.

There has been a recent trend to contract an overall tolling rate where payment is on the basis of LNG regasified and is expressed as $\$ /$ mmbtu. However the actual rate will be dependent on the terminal utilisation (load factor). This is often in the region of $50 \%$, which would double the actual rate. QED Consulting ${ }^{56}$ quotes estimated tolling rates (tariffs) in the range $\$ 0.60-0.94 / \mathrm{mmbtu}$ based on a $50 \%$ load factor. The contract with Excelerate for the Puerto Rico FSRU Aguirre terminal states $\$ 0.47 / \mathrm{mmbtu}^{57}$. The rate for the first Bangladesh terminal is also stated to be $\$ 0.47 / \mathrm{mmbtu}^{58}$. For the second Bangladesh terminal $\$ 0.45$ has been stated. Assuming a $50 \%$ load factor the actual rates will again be around $\$ 1 / \mathrm{mmbtu}$. This is half the rate for an onshore terminal where the industry norm is $\$ 2 / \mathrm{mmbtu}$ for $50 \%$ utilisation factor ( $\$ 1 / \mathrm{mmbtu}$ at $100 \%$ ) which aligns with FSRUs costing $50-60 \%$ of the equivalent onshore terminal.

\footnotetext{
${ }^{5}$ http://pdf.usaid.gov/pdf docs/PA00KWB5.pdf

${ }^{56}$ http://pdf.usaid.gov/pdf docs/PA00KWB5.pdf

57 https://www2.aeepr.com/Documentos/Ley57/CONTRATOS\%20GENERAL/2014-03-

17\%20Time\%20Charter\%20Party\%20and\%20LNG\%20Storage\%20and\%20Regasification\%20Agreement\%20(wo\%20schedul es).pdf

${ }^{58}$ http://www.dhakatribune.com/business/2017/03/30/summit-get-work-Ing-terminal-maheskhali/
} 


\section{Chapter 10. SWOT Analysis}

A summary of the strengths, weaknesses, opportunities and threats of FSRU projects is shown in table 10.1. These are discussed in the sections below.

Table 10.1 SWOT Analysis

\begin{tabular}{|c|c|}
\hline Strengths & Weaknesses \\
\hline $\begin{array}{l}\text { Lower (capital) cost and less capital outlay - better cash flow } \\
\text { and return on Investment. Ideal for smaller independent } \\
\text { energy companies where raising capital may be difficult }\end{array}$ & $\begin{array}{l}\text { Storage and regas capacity limited to maximum ship size } \\
\text { - nominally } 173,000 \mathrm{~m}^{3} \text { and } 6 \mathrm{mtpa} \text { albeit larger vessels } \\
\text { have been constructed but on a project dedicated basis }\end{array}$ \\
\hline $\begin{array}{l}\text { Shorter schedule - earlier gas to market improving } \\
\text { competitiveness and securing the supply contract }\end{array}$ & $\begin{array}{l}\text { Expansion more difficult than onshore requiring a larger } \\
\text { replacement unit or adding another FSRU }\end{array}$ \\
\hline $\begin{array}{l}\text { Option to lease (most are) improving cash flow and return on } \\
\text { investment - not sunk cost as onshore but increased OPEX }\end{array}$ & $\begin{array}{l}\text { Typically less buffer storage - most land terminals have } 2 \\
\text { x 160,00 cm tanks }\end{array}$ \\
\hline Can be relocated to meet seasonable gas demands & $\begin{array}{l}\text { Offshore located FSRUs sensitive to weather windows - } \\
\text { not an issue with inshore }\end{array}$ \\
\hline $\begin{array}{l}\text { Easier permitting process, minimizes the 'not in my back yard' } \\
\text { issues frequently associated with onshore }\end{array}$ & $\begin{array}{l}\text { Limited local content during construction - onshore } \\
\text { terminals are major civil engineering projects }\end{array}$ \\
\hline $\begin{array}{l}\text { Shipyard construction results in very high confidence on } \\
\text { delivery cost and completion date }\end{array}$ & $\begin{array}{l}\text { No room on FSRU for nitrogen balancing to adjust heating } \\
\text { value - could be onshore }\end{array}$ \\
\hline \multicolumn{2}{|l|}{$\begin{array}{l}\text { Shipyard construction minimises local disruption compared } \\
\text { with onshore which are major civil engineering projects }\end{array}$} \\
\hline \multicolumn{2}{|l|}{$\begin{array}{l}\text { FSRU can be reassigned to LNG tanker use thus minimizing } \\
\text { utilisation risk if gas demand falls }\end{array}$} \\
\hline Opportunities & Threats \\
\hline To purchase outright if long term market is identified & FSRU owner goes into liquidation - covered by contract \\
\hline Deliver early gas whilst establishing long term market need & Not approved due to low local content \\
\hline $\begin{array}{l}\text { Ideal component for providing early gas for a power project - } \\
\text { or even as a complete floating power barge }\end{array}$ & $\begin{array}{l}\text { Not approved as not regarded as a permanent facility and } \\
\text { major infrastructure as is onshore }\end{array}$ \\
\hline For new smaller gas markets including gas to power projects & $\begin{array}{l}\text { Major port development costs make the project } \\
\text { uneconomic e.g. breakwater- could apply to onshore too. }\end{array}$ \\
\hline
\end{tabular}

Source: By author 

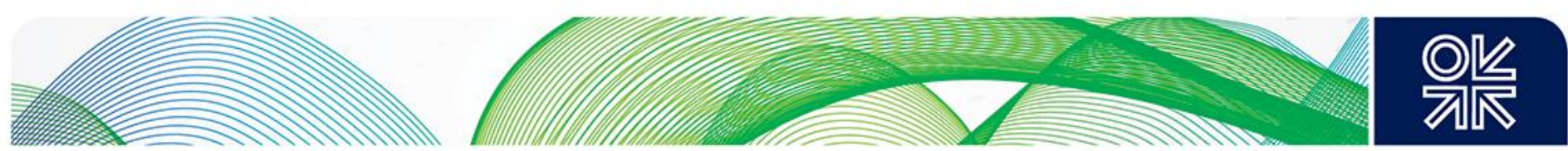

\section{Strengths}

As discussed in chapter 6 the capital cost of an FSRU terminal can typically be $50-60 \%$ of the equivalent onshore terminal due to its compact size and efficient shipyard costs compared to the larger plot and major civil engineering features of an onshore 'stick built' terminal. This is a significant difference and can greatly improve the project economics with the lower capital outlay and the improved cash flow. Also it would be easier for the smaller independent energy companies to arrange the financing of a smaller loan.

Similarly the shorter schedule to deliver first gas will improve the cash flow and the project economics. Also the ability to deliver first gas more quickly is likely to improve the competitiveness of the offering.

Most FSRUs are leased as the vessel is owned by a shipping company and can be reassigned on project completion. This is a major advantage over onshore terminals where the construction cost must be regarded as a sunk cost. The leasing arrangement again improves cash flow and improves the project economics for shorter term projects. For longer term projects e.g. 20 years it is likely that outright purchase would be cheaper and this is an option with some of the recent FSRU contracts e.g. Lithuania ${ }^{59}$ and Bangladesh. Further the FSRUs for Toscana, Italy and Gazprom, Kaliningrad were purchased outright because they are likely to be longer term installations and they are both operated by major energy companies who can raise cheaper capital.

As a flexible asset an FSRU can be relocated to meet seasonal demands. This was the case for the Brazil and Kuwait terminals. In the case of Brazil60,61 this was to meet seasonal power demands due to the lack of rainfall for the hydroelectric power plants. For Kuwait ${ }^{62}$ the peak demand for gas for air conditioning runs from March to November leaving the FSRU to operate as an LNG tanker for the winter months maximizing the utilization of the asset. However it appears that more recent FSRU terminals have been contracted on a more permanent all year gas supply basis.

Permitting issues for onshore terminals are common due to the NIMBY63 effect. Onshore terminals are large civil engineering contracts requiring large movement of materials and accommodating large labour forces. This frequently leads to major delays. Conversely the FSRU is built in a shipyard resulting in minimum construction impact at the terminal site. The only significant impact at the terminal site is the construction of the necessary port facilities for the FSRU mooring and offloading. In an existing port this is likely to be minimal but could be major if a new port or breakwater is required.

FSRU shipyards are located mainly in Korea (Hyundai, Samsung \& DSME) and have an excellent record for delivery on time. This is not necessarily the same for onshore terminals where weather and labour issues frequently lead to delays. The higher confidence of on time gas delivery from an FRSU is a major advantage, particularly if penalties are involved for late gas supply.

Similarly construction in a shipyard minimises the impact of local construction activities such as large movements of civil engineering materials, steel plate and large equipment. This disruption is frequently a major issue in securing planning permission for onshore terminals particularly in environmentally sensitive areas.

As already mentioned, for Kuwait and Brazil the ability to relocate an FSRU terminal offers complete flexibility of where the asset is used increasing the utilization factor of the terminal and reducing costs. It has been reported that the average utilization factor of onshore terminals is just $30-40 \% 64$.

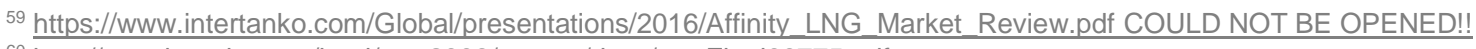

60 http://members.igu.org/html/wgc2009/papers/docs/wgcFinal00775.pdf

${ }^{61}$ http://www.Ingworldnews.com/brazil-Ing-imports-soar-136-pct-in-first-half-of-december/

62 http://af.reuters.com/article/energyOilNews/idAFL8N13T1RJ20151204

${ }^{3}$ Not In My Back Yard

64 file:///C:/Users/Brian/Downloads/IGU World LNG Report 2016\%20(1).pdf COULDN'T OPEN THIS FILE
} 

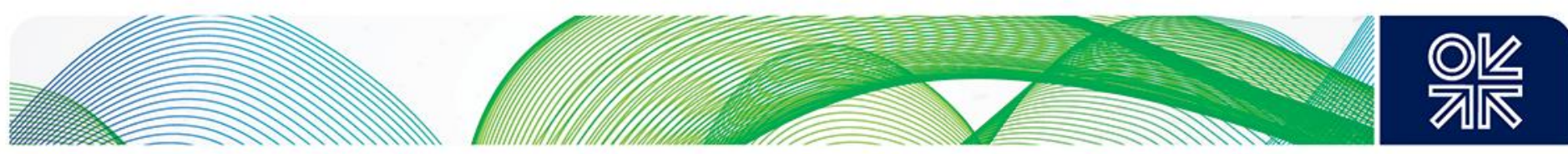

\section{Weaknesses}

Industry standard FSRUs are essentially limited to $173,000 \mathrm{~m}^{3}$ storage and nominal $6 \mathrm{mtpa}$ throughput. Storage of 263,000 $\mathrm{m}^{3}$ can be offered based on a Qmax (Uruguay) but this is a bespoke order. The same is true for the $330,000 \mathrm{~m}^{3} \mathrm{FSRU}$ for Kaliningrad. The industry standard sized vessels are well suited for most of the gas to power projects with just $1 \mathrm{mtpa}$ producing $800 \mathrm{MW}$ using a combined cycle 65 power plant.

FSRUs are constructed as shipyard built units to a general industry standard in terms of storage and capacity. The compact and defined nature of the units which are based on LNG tankers does not allow expansion. For onshore terminals space is normally allowed for further tank(s) and regasification units. This is not practical for a ship shaped vessel. If more storage is required this weakness could be mitigated by adding a floating storage unit (FSU). If both more storage and more regas capacity is needed this could be provided by replacing the FSRU with a larger unit e.g. Dubai Explorer ${ }^{66}$ or by adding a second or even third FSRU. Any major modifications to a FSRU would require the vessel being returned to a shipyard.

FSRU storage capacities of typically $135,000-173,000 \mathrm{~m}^{3}$ do not provide sufficient buffer storage for delivery by $173,000 \mathrm{~m}^{3}$ tankers. This may require the tanker to wait until sufficient capacity is available in the FSRU and incurring demurrage charges. This is more of an issue for FSRUs with smaller $135,000 \mathrm{~m}^{3}$ FSRUs being supplied from 173,000 $\mathrm{m}^{3}$ tankers.

FSRUs located in open water are sensitive to weather conditions for LNG transfer or connection to a gas pipeline. This needs to be considered in determining whether a FSRU is a practical option. This assessment would need to consider the meteorological data for the location. This is not an issue for inshore FSRUs.

Construction of FSRUs in foreign shipyards does not provide the local large workforce required to construct an onshore terminal which is a large civil engineering project employing a peak labour force of $800-1,000$ people. The approval of large infrastructure projects is often dependent on local employment and value creation for the local economy.

Finally, the compact nature of an FSRU does not allow for the storage of a large quantity of nitrogen to dilute (ballast) the LNG to meet local pipeline specifications. This only affects gas being supplied to a grid with tight specifications. This is not an issue for gas to power projects where higher calorific value gas is preferred.

\section{Opportunities}

Whilst FSRUs are normally leased there is an opportunity to purchase outright subject to contract arrangements. This is ideal for small early gas developments which may evolve into larger long term supply contracts. This is the situation for the Lithuanian and Bangladesh FSRUs.

Similarly FSRUs are ideal for the supply of early gas while a permanent onshore terminal is being considered or constructed.

Many FSRU providers are now offering the facility of including power generation ${ }^{67}$ either on the vessel i.e. a power barge or through a strategic partnership ${ }^{68}$. This would provide the opportunity to bring in a complete power generation facility simply and quickly and connect directly to the grid.

\footnotetext{
${ }^{65}$ https://powergen.gepower.com/resources/knowledge-base/combined-cycle-power-plant-how-it-works.html ${ }^{66}$ http://excelerateenergy.com/project/iebel-ali-Ing-import-terminal/

http://www.wartsila.com/docs/default-source/oil-gas-documents/gastech/mobile-Ing-solution.pdf?sfvrsn=2

${ }^{68}$ https://globenewswire.com/news-release/2016/06/20/849837/10163578/en/Golar-and-Stonepeak-launch-Golar-Power.html
} 

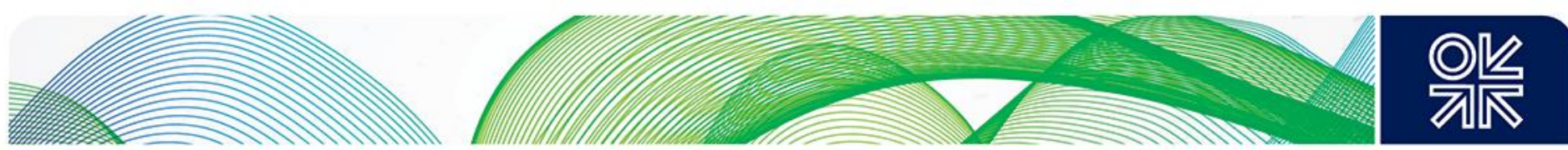

\section{Threats}

It is possible that an FSRU provider and operator could go into liquidation. They are, however, major shipping companies with large asset bases. However some newer smaller players are looking to enter the market and their financial strength should be checked. There is also the threat that shipyards could go into liquidation ${ }^{69}$ and this also needs to be checked.

There is the risk that the project may not be approved by the local authorities due to the low local content because the vessel was built in a foreign shipyard. Onshore terminals are, on the contrary, major civil engineering projects providing major job opportunities for local companies in terms of goods, materials and services.

The facility by its nature is flexible and can be easily removed unlike an onshore terminal. This could lead to a perception that a secure gas supply is not being provided. This is likely to be more of a concern for a strategic gas supply.

Another possible threat is the high cost of developing port infrastructure. Most FSRU developments are located in existing ports or ports that are part of a country's overall development plan, thus offsetting the costs. It the port has to be built specifically and requires major facilities such as a breakwater this could add a major cost and make the project uneconomic. It is believed this was one of the reasons for Emirates LNG to cancel its proposed terminal at Fujairah ${ }^{70}$ and look for other possible sites.

\footnotetext{
$69 \mathrm{http://splash247.com/dsme-can-expect-no-more-bailouts-this-year/}$

${ }^{70} \mathrm{http}: / /$ interfaxenergy.com/gasdaily/article/25070/emirates-Ing-considering-sites-for-new-terminal
} 

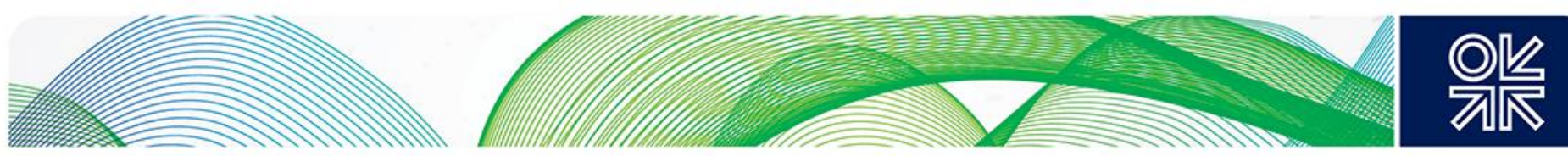

\section{Chapter 11. Screening Questionnaire}

Table 11.1 outlines the key considerations to determine whether an import terminal is best suited for an FSRU or onshore option. This is only intended as a very preliminary guide and in all cases a feasibility study must be undertaken to ensure that all the factors pertinent to that specific project have been considered and evaluated.

Looking at the decision factors a FSRU is likely to be preferred over an onshore terminal if the following applies:

- There is short term market need - leasing cheaper than sunk cost, FSRU reassigned

- There is fast track need to supply gas - onshore terminals take 3-5 years to construct

- Capacity is less than 6 mtpa - greater would need 2 FSRUs, OK for short term, not long term

- Send out capacity not likely to increase - much easier to add extra vaporisers onshore

- $\quad$ No need for strategic storage - largest vessel Qmax 266,000 m³

- Major permitting issues for onshore terminal

- No space available for an onshore terminal

- Offshore FSRU if entrance to harbour too shallow requiring dredging (dredging is an ongoing maintenance cost too)

- Independent power company with limited capital available or requires to keep plant off the balance sheet 

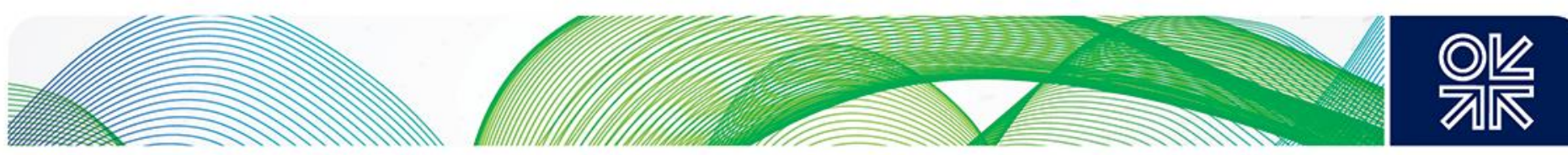

Table 11.1 Decision Factors

\begin{tabular}{|c|c|c|c|}
\hline Feature & FSRU & Onshore & Comments \\
\hline Send-out $<6$ mtpa & $\mathbf{x}$ & & $\begin{array}{l}\text { Some FSRUs are capable of peak send-out }>6 \text { mtpa but not } \\
\text { guaranteed. } 8 \text { mtpa may be possible with newer vessels. } \\
\text { Option for } 2 \text { FSRUs. }\end{array}$ \\
\hline $\begin{array}{l}\text { Additional capacity } \\
\text { required in future }\end{array}$ & & $\mathbf{x}$ & $\begin{array}{l}\text { Expanding FSRU capacity not realistic - space on onshore site } \\
\text { allows additional vaporisers to be easily added }\end{array}$ \\
\hline $\begin{array}{l}\text { Storage }>170,000 \\
\mathrm{~m}^{3}\end{array}$ & & $\mathbf{x}$ & $\begin{array}{l}\text { Max vessel size } 170,000 \mathrm{~m}^{3} . \text { Qmax option is available at } \\
266,000 \mathrm{~m} 3 \text { but this would be bespoke. Could add FSU. }\end{array}$ \\
\hline $\begin{array}{l}\text { Additional storage } \\
\text { required in future }\end{array}$ & & $\mathbf{x}$ & $\begin{array}{l}\text { Expanding FSRU capacity no realistic - space on onshore site } \\
\text { allows for further tanks. Could consider adding FSU. }\end{array}$ \\
\hline $\begin{array}{l}\text { Strategic storage } \\
\text { required }\end{array}$ & & $\mathbf{x}$ & FSRU is a flexible (removable) option \\
\hline $\begin{array}{l}\text { No existing harbour } \\
\text { available }\end{array}$ & $\mathbf{x}$ & & $\begin{array}{l}\text { Offshore FSRU with pipeline to shore best option as } \\
\text { harbour/breakwater construction expensive }\end{array}$ \\
\hline $\begin{array}{l}\text { Water depth }<14 \mathrm{~m} \\
\text { at harbour entrance }\end{array}$ & $\mathbf{x}$ & & $\begin{array}{l}\text { Dredging expensive and ongoing OPEX. Offshore FSRU with } \\
\text { pipeline to shore possible best low cost option }\end{array}$ \\
\hline $\begin{array}{l}\text { Onshore permitting } \\
\text { difficult - NIMBY }\end{array}$ & $\mathbf{x}$ & & $\begin{array}{l}\text { Onshore terminals are major construction projects involving } \\
\text { major earth moving and heavy construction materials }\end{array}$ \\
\hline $\begin{array}{l}\text { Short term gas } \\
\text { market need }\end{array}$ & $\mathbf{x}$ & & $\begin{array}{l}\text { Possibly while longer term onshore terminal planned or just to } \\
\text { meet seasonal needs }\end{array}$ \\
\hline $\begin{array}{l}\text { Fast track need for } \\
\text { gas market }\end{array}$ & $\mathbf{x}$ & & $\begin{array}{l}\text { Onshore terminals typically take } 4 \text { years to construct. Recent } \\
\text { Ain Sokhna } 2 \text { terminal operational in just } 5 \text { months }\end{array}$ \\
\hline $\begin{array}{l}\text { Financing difficult } \\
\text { and lack of capital }\end{array}$ & $\mathbf{x}$ & & $\begin{array}{l}\text { FSRU can be leased but still need to finance harbour works } \\
\text { and pipeline connection to customers/grid }\end{array}$ \\
\hline $\begin{array}{l}\text { No land available for } \\
\text { onshore terminal }\end{array}$ & $\mathbf{x}$ & & Land reclamation may be possible but is an expensive option. \\
\hline $\begin{array}{l}\text { High local content } \\
\text { needed }\end{array}$ & & $\mathbf{x}$ & $\begin{array}{l}\text { Limited local content with FSRU likely built in Far East shipyard } \\
\text { albeit some local work likely for harbour and infrastructure }\end{array}$ \\
\hline
\end{tabular}

Source: By author 

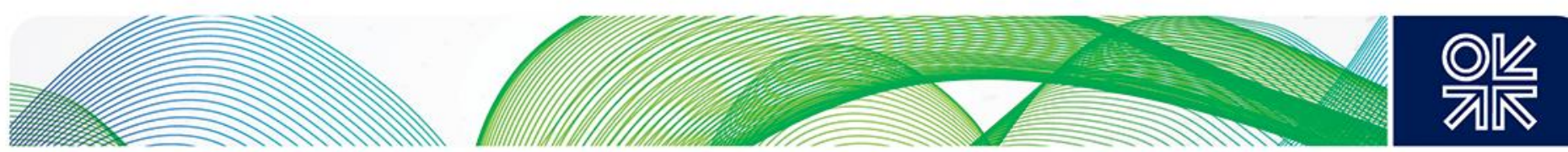

\section{Chapter 12. Floating Storage Units (FSUs)}

The four FSUs currently in operation are listed in table 12.1. They are all relatively old LNG tankers (with the exception of the Golar Arctic) that have been converted to operate as floating storage units.

A further FSU is under conversion for Teekay LNG for the Bahrain Import Terminal. Interestingly this is the conversion of a new LNG tanker being constructed by $\mathrm{DSME}^{71}$. The charter period is for 20 years.

Table 12.1 FSUs in Operation

\begin{tabular}{|c|c|c|c|c|c|c|}
\hline Owner & Vessel Name & Status & $\begin{array}{c}\text { Storage } \\
\mathbf{m 3}\end{array}$ & $\begin{array}{c}\text { Original } \\
\text { Build }\end{array}$ & Conversion & $\begin{array}{c}\text { FSU } \\
\text { Delivered }\end{array}$ \\
\hline Bumi Armada & $\begin{array}{c}\text { Armada LNG } \\
\text { Mediterrana }\end{array}$ & $\begin{array}{c}\text { LNG Tanker } \\
\text { converted to FSU } \\
\text { service }\end{array}$ & 125,000 & 1985 & Keppel $^{72}$ & $\begin{array}{c}\text { Malta } \\
2016\end{array}$ \\
\hline Petronas & Tenaga Satu & $\begin{array}{c}\text { LNG Tanker } \\
\text { converted to FSU } \\
\text { service }\end{array}$ & 130,000 & 1982 & MMHE $^{73}$ & $\begin{array}{c}\text { Melaka } \\
2012\end{array}$ \\
\hline Petronas & Tenaga Empat & $\begin{array}{c}\text { LNG Tanker } \\
\text { converted to FSU } \\
\text { service }\end{array}$ & 130,000 & 1981 & Keppel $^{74}$ & $\begin{array}{c}\text { Melaka } \\
2012\end{array}$ \\
\hline Golar LNG & Golar Arctic & $\begin{array}{c}\text { LNG Tanker } \\
\text { converted to FSU } \\
\text { service }\end{array}$ & 138,000 & 2003 & Keppel $^{75}$ & $\begin{array}{c}\text { Jamaica } \\
2016\end{array}$ \\
\hline
\end{tabular}

Source: By author

The conversion work will cover the additional process plant, piping, control systems, utility systems and crew needs for the vessel to operate as a permanently moored facility rather than an ocean going vessel. This would typically include:

- If side-by-side loading using cryogenic hoses is not accepted then import loading arms and a vapour return arm would need to be installed on the FSU. Alternatively a cross jetty arrangement could be used but this would require twice the number of arms - one set connecting to the supply tanker and the second set to the FSU - an expensive option.

- Modifications to the tank unloading pumps to supply LNG to the onshore regasification facilities at a much lower rate than for normal LNG tanker unloading. For normal tanker operations the pumps are sized to unload at the rate $12,000 \mathrm{~m}^{3} / \mathrm{h}$ over a 24 hour period. However for a $4 \mathrm{mtpa}$ regasification facility the LNG send-out rate is more typically $1,000 \mathrm{~m}^{3} / \mathrm{h}$ and on a continuous not intermittent basis i.e. just $8 \%$ of the unloading rate.

- The addition of much smaller LNG export manifold piping and unloading arms for this lower send-out rate.

\footnotetext{
http://www.Ingworldnews.com/dsme-teekay-upgrades-Ing-carrier-order-to-fsu/

${ }^{72}$ http://www.tradewindsnews.com/weekly/375162/ship-conversion-for-malta-fsu-kicks-off

${ }^{73}$ http://www.ship-technology.com/news/news127884.html

${ }^{74} \mathrm{http}: / /$ www.kepcorp.com/en/news item.aspx?sid=3100

${ }^{75}$ http://gozonews.com/63353/prime-minister-at-the-sail-away-ceremony-of-armada-Ing-mediterrana/
} 

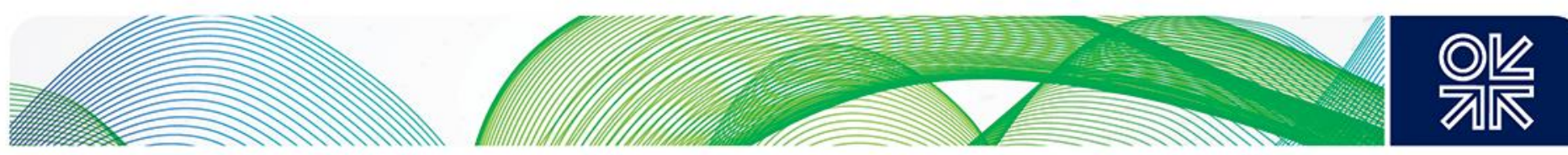

- Facilities to manage the BOG if not sent onshore. This could be by a recondenser on the FSU or combustion in the ship's boiler and dumped as steam in the condenser.

- Modifications to the utility systems for permanent mooring and meeting the differing crew needs when compared to a sailing operation. This would probably include import of onshore power as a cheaper alternative to onboard generation.

- Modifications to the hull and propulsion systems if the classification is changed to an offshore installation including those required by the harbour authorities. These are likely to be minimal. No modifications are likely if classification remains as a ship.

- Modifications to the mooring system to enable the vessel to stay moored during bad weather. LNG tankers have the option to disconnect in these situations.

Examples of the above list are the modifications made to the Golar Arctic for the Malta FSU76:

- $\quad$ LNG send-out from $10-150 \mathrm{~m}^{3} / \mathrm{h}$

- BOG sent to shore for power plant use

- Shore power supply to optimise project economics

- New auxiliary boilers and generating set for Boil Off Gas management and power redundancy when disconnected from jetty

- No dry docking for 18 years by using FPSO coatings and an in-water inspection philosophy

- Environmentally friendly design for propeller shaft and underwater systems to ensure no discharge to sea at any time

- Spread-mooring arrangements for use in extreme weather conditions

- Side by Side transfer of LNG by approaching LNG Carriers through LNG hoses

${ }^{76} \mathrm{https}: / /$ www.linkedin.com/pulse/maltas-fsu-set-sail-away-rachel-shin 

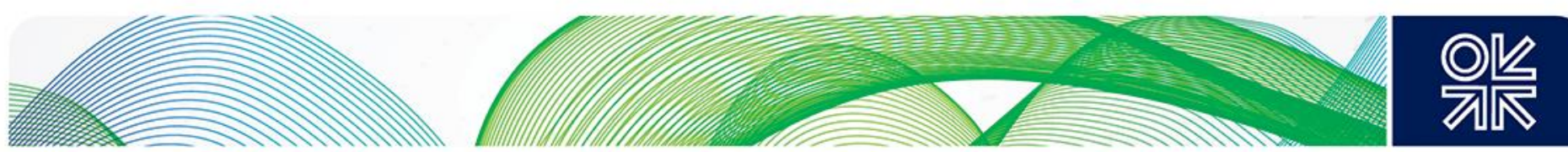

\section{Chapter 13. Floating Power Barges}

Gas to power is a key market for LNG and the majority of the current FSRU projects and prospects are linked to smaller onshore power plants typically in the range of 100-500 MW. As an example the current Jamaica terminal feeds LNG to a $120 \mathrm{MW}$ plant ${ }^{77}$ and a proposed new $190 \mathrm{MW}$ plant. The Maltese terminal feeds LNG a $200 \mathrm{MW}$ power plant ${ }^{78}$.

An alternative to onshore power generation would be to locate the power plant on the FSRU or on a separate barge and several proposals have been made to offer this option.

Golar LNG Energy has developed concepts for a power plant installed on the FSRU that would deliver 100-300 MW. The power generation plant would be located behind the accommodation facilities away from the LNG storage and pipework. This arrangement would not require gas arms as the power would be generated onboard and power lines would be connected directly to the onshore grid. Golar Power Ltd79 has recently been formed as a 50/50 joint venture between Golar LNG and Stonepeak Infrastructure Partners but appears to be focusing on providing solutions comprising a FSRU with an onshore located power plant. The Golar Power Ltd joint venture is able to offer a one stop shop which will minimise the owner's risks and costs.

An alternative is to locate the power plant on a purpose built barge moored adjacent to the FSRU with the gas being transferred either by gas arms or high pressure hoses. Gas feed to a gas turbine driven power would be typically 40 bar g pressure - lower than a typical gas grid of 100 bar g. Several companies have been developing proposals including:

- Applied Engineering 80

- Karpower ${ }^{81}$

An interesting article titled 'Electrical Power Generation Aboard LNG FSRUs' 82 discussion a new concept referred to as the FPGU (Floating Power Generation Units).

77 http://iamaica-gleaner.com/article/lead-stories/20161114/jamaica-become-caribbean-hub-Ing-mobay-plant-completed-oldharbour-bay

${ }^{78} \mathrm{http}: / /$ www.power-technology.com/projects/malta-Ing-to-power-project-marsaxlokk/

${ }^{79} \mathrm{http}: / /$ worldmaritimenews.com/archives/tag/golar-power-Itd/

${ }^{80} \mathrm{http}: / /$ appliedengineering.com.sg/floating-Ing-power-barge/

${ }^{81}$ https://constructionreviewonline.com/2016/06/ghana-to-install-400mw-of-power-barge-in-two-months-time/

82 http://pennwell.sds06.websds.net/2013/bangkok/pga/papers/T3S2O2-paper.pdf 

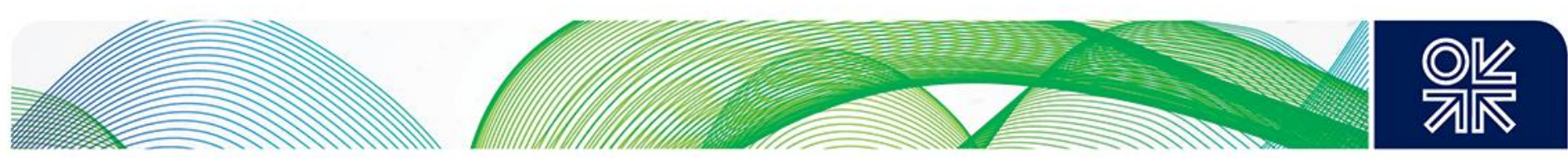

\section{Chapter 14. Conclusions}

The FSRU business has grown rapidly since the first vessel was installed in 2011 - just 16 years ago. There are now 27 vessels of which 23 are in operation as terminals and 4 currently assigned to LNG tanker service. A further 10 are currently under construction with options placed with the shipyards for 10 more. The IGU has estimated that there could be 50 vessels in operation by 2025 offering a FSRU based regas capacity in excess of $200 \mathrm{mtpa}$, which is $60 \%$ of the world's LNG production in 2016. FSRUs were pioneered by Excelerate Energy and Golar LNG who developed this market from different viewpoints. Excelerate providing a 'flexible pipeline' solution with vessel reallocation at the end of the delivery term and Golar looking to add value to old LNG tankers that were reaching the end of their economic life.

This rapid growth has been mainly due to FSRUs typically costing just $50-60 \%$ of a new onshore terminal and construction in just 3 years compared to 4-5 years for onshore. An LNG tanker conversion is even quicker at $12-18$ months. Also being a reusable asset means the units can be moved to meet specific market needs compared to onshore which are fixed and a sunk cost. Leasing with the option to buy also offers flexibility.

The first FSRUs were based on nominal 125,000-140,000 $\mathrm{m}^{3}$ tankers with send out rates of 2-3 mtpa but the recent new vessels are larger - typically $173,000 \mathrm{~m}^{3}$ with nominal send out rates up to $6 \mathrm{mtpa}$ with full boil-off-gas management facilities as used on land based terminals. The largest storage capacity FSRU is the MOL GNL Del Plata in Uruguay based on a Qmax 263,000 $\mathrm{m}^{3}$ vessel. However an order has just been placed with $\mathrm{HHI}$ for a $330,000 \mathrm{~m}^{3} \mathrm{FSRU}$ for Karnatarka, India.

New build FSRUs typically cost $\$ 250-300 \mathrm{~m}$ to construct and a conversion costs $£ 80-100 \mathrm{~m}$. Leasing day rates are in the range of $\$ 110-160,000 /$ day depending on the capacity and the charter period. This day rate is for the vessel only and operating costs need to be added which are typically $\$ 20,000$ $45,000 /$ day. These rates typically represent an overall regasification cost of $\$ 0.4 / \mathrm{mmbtu}$ for a $100 \%$ load factor but $\$ 0.7 / \mathrm{mmbtu}$ is more realistic at a $50 \%$ load factor. The 15 -year charter rate for the recent Bangladesh FSRU has been stated as $\$ 0.47 / \mathrm{mmbtu}$. Fuel costs must be added to these costs which are a function of terminal send-out and are significant. Charter periods for early FSRUs were typically 10-15 years but of late much shorter as the owners are more confident about reassigning the FSRU at the end of the charter period. The recent Egypt FSRU lease is for just 5 years - ideal for short term market needs which could not be economically met by using an onshore terminal.

The total cost of the floating terminal facility comprises not only the vessel but also the infrastructure for mooring and connection of the pipeline to the gas network. This can typically represent $\$ 50-100 \mathrm{~m}$ but more if a breakwater is required, and this is a sunk cost. The infrastructure has traditionally been managed by the energy company but recently the FSRU owners are being asked to include this in their scope and offer a one-stop-shop. This is very attractive to the smaller independent energy companies who have limited resources to manage projects.

By offering a low cost, fast track and flexible option when compared to onshore terminals FSRUs offer an excellent opportunity to grow the LNG market internationally. An example is the gas to power business being developed by smaller independent power companies who wish to serve developing nations by offering a clean and efficient source of fuel for power generation. Most of the current FSRU projects and the identified prospects fall into this category. This has encouraged many FSRU companies to consider offering a complete package with a power generation plant installed either on the FSRU, on an adjacent barge or ship or onshore. This combined offering provides a one-stop-shop solution which is ideal for the smaller independent companies. 

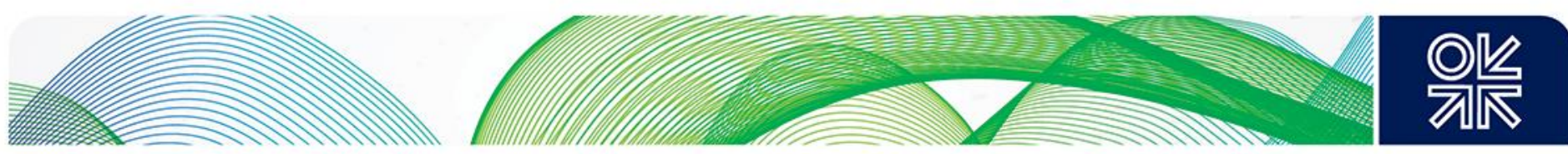

Whilst FSRUs offer many advantages over onshore terminals they do have some drawbacks:

- Cannot be expanded onsite. Capacity expansion would need an additional vessel (recent Dubai and Egypt expansions) or replacement by a larger vessel as was the case for Brazil and Kuwait.

- Limited local content by not providing the large number of construction jobs offered by onshore terminals which are large civil engineering projects.

- Offshore FSRUs will probably have weather window limitations for LNG transfer from the supply tanker and this must be factored in. This does not apply to inshore FSRUs.

- FSRU vessel storage is in the range $130,000-170,000 \mathrm{~m}^{3}$ and if being supplied by the larger $170,000 \mathrm{~m}^{3}$ supply tankers this would probably lead to expensive offloading delays until the storage capacity became available. This needs to be considered in the supply logistics.

- They are a movable asset and are unlikely to satisfy national strategic storage needs unless measures are taken to ensure the vessel cannot be moved.

Several other challenges are being faced by the FSRU vessel providers and these include:

- There are many FSRU prospects and the owners have limited resources and need to prioritise their resources. To prepare a proposal is an expensive process and this high cost needs to focus on realistic and winnable projects.

- FSRU owners are LNG tanker companies and in some cases are being asked to include the infrastructure in their scope on a turnkey basis which is outside their traditional core skill set. To deliver this they need to find suitable partnerships but this means working with unfamiliar local contractors.

- The potential market can be divided into 2 major groups - smaller send-out rates at 200-300 mmscfd (1.7-2.5 mtpa) and larger capacity 500-700 mmscfd (4-6 mtpa). This presents a major challenge for the speculative building of new vessels in deciding what capacity to build for. For the lower range conversions are now being actively considered as charter rates for older LNG tankers are low and this reverses the recent trend for all new builds.

The future for FSRUs looks extremely promising with industry reports predicting a further 25 vessels in operation in the next 8 years -3 terminals per year. This is endorsed by the fact that the major FSRU service providers are ordering new vessels at a major cost of $\$ 250 \mathrm{~m}$ on a speculative basis and that established LNG tanker owners are now entering the market. As mentioned in the report it is the flexibility of FSRUs which is their key advantage - to be able to deliver gas quickly and for short term contracts. A recent example being the second Ain Sokhna terminal where gas was delivered in just 5 months from issue of the tender and for a short term period of just 5 years. 

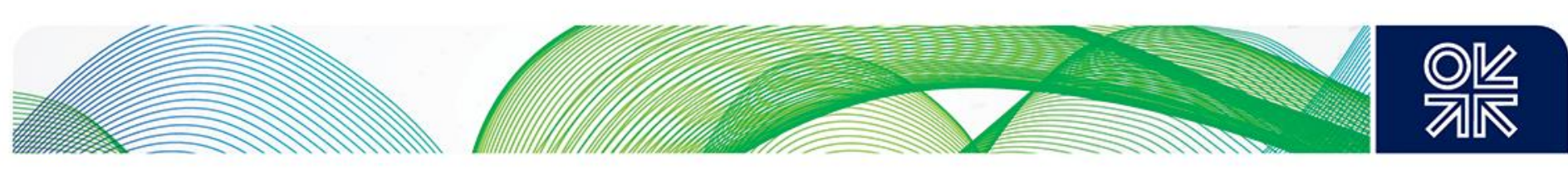

\section{Appendix 1. Current FSRU Fleet Details}

The following table provides summary details of the current FSRU fleet in operation or delivered and pending start up and operation. More details and photographs of the vessels can be accessed through the hyperlinks.

\begin{tabular}{|c|c|c|c|c|c|c|c|}
\hline $\begin{array}{l}\text { Vessel } \\
\text { Name }\end{array}$ & Status & $\begin{array}{c}\text { Storage } \\
\mathrm{m}^{3}\end{array}$ & $\begin{array}{l}\text { mmscfd } \\
\text { Baseload }\end{array}$ & mtpa & Delivered & $\begin{array}{l}\text { Open/ or } \\
\text { Closed } \\
\text { Loop }^{83}\end{array}$ & $\begin{array}{l}\text { Vessel Details \& } \\
\text { Photographs }\end{array}$ \\
\hline \multicolumn{8}{|c|}{ Excelerate Energy } \\
\hline Excelsior & Operating & 138,000 & 500 & 4.1 & 2005 & $\begin{array}{l}\text { Open \& } \\
\text { Closed }\end{array}$ & $\begin{array}{l}\text { http://excelerateenergy.c } \\
\underline{\text { om/fleet/ }}\end{array}$ \\
\hline Express & Operating & 150,900 & 500 & 4.1 & 2009 & $\begin{array}{l}\text { Open \& } \\
\text { Closed }\end{array}$ & $\begin{array}{l}\text { http://excelerateenergy.c } \\
\underline{\text { om/fleet/ }}\end{array}$ \\
\hline Excellence & Operating & 138,000 & 500 & 4.1 & 2005 & $\begin{array}{l}\text { Open \& } \\
\text { Closed }\end{array}$ & $\begin{array}{l}\text { http://excelerateenergy.c } \\
\text { om/fleet/ }\end{array}$ \\
\hline Explorer & Operating & 150,900 & 500 & 4.1 & 2008 & $\begin{array}{l}\text { Open \& } \\
\text { Closed }\end{array}$ & $\begin{array}{l}\text { http://excelerateenergy.c } \\
\underline{\text { om/fleet/ }}\end{array}$ \\
\hline Experience & Operating & 173,000 & 800 & 6.6 & 2014 & $\begin{array}{l}\text { Open \& } \\
\text { Closed }\end{array}$ & $\begin{array}{l}\text { http://excelerateenergy.c } \\
\underline{\text { om/fleet/ }}\end{array}$ \\
\hline Exquisite & Operating & 150,900 & 500 & 4.1 & 2015 & $\begin{array}{l}\text { Open \& } \\
\text { Closed }\end{array}$ & $\begin{array}{l}\text { http://excelerateenergy.c } \\
\underline{\text { om/fleet/ }}\end{array}$ \\
\hline Excelerate & Operating & 138,000 & 500 & 4.1 & 2006 & $\begin{array}{l}\text { Open \& } \\
\text { Closed }\end{array}$ & $\begin{array}{l}\text { http://excelerateenergy.c } \\
\underline{\text { om/fleet/ }}\end{array}$ \\
\hline Expedient & Operating & 150,900 & 500 & 4.1 & 2009 & $\begin{array}{l}\text { Open \& } \\
\text { Closed }\end{array}$ & $\begin{array}{l}\text { http://excelerateenergy.c } \\
\underline{\text { om/fleet/ }}\end{array}$ \\
\hline Exemplar & Operating & 150,900 & 500 & 4.1 & 2010 & $\begin{array}{l}\text { Open \& } \\
\text { Closed }\end{array}$ & $\begin{array}{l}\text { http://excelerateenergy.c } \\
\underline{\text { om/fleet/ }}\end{array}$ \\
\hline \multicolumn{8}{|l|}{ Golar LNG } \\
\hline Golar Spirit & $\begin{array}{l}\text { Retire } \\
\text { June } \\
2017 \\
\end{array}$ & 129,000 & 242 & 2.0 & 2008 & Closed & $\begin{array}{l}\text { http://www.golarlng.com/ } \\
\text { our-fleet/floating-storage- } \\
\text { and-regasification-units }\end{array}$ \\
\hline Golar Winter & Operating & 138,000 & 500 & 4.1 & 2006 & $\begin{array}{l}\text { Open \& } \\
\text { Closed }\end{array}$ & $\begin{array}{l}\text { http://www.golarlng.com/ } \\
\text { our-fleet/floating-storage- } \\
\underline{\text { and-regasification-units }}\end{array}$ \\
\hline $\begin{array}{l}\text { Golar } \\
\text { Freeze }\end{array}$ & Operating & 125,000 & 475 & 3.9 & 2010 & $\begin{array}{l}\text { Open } \\
\text { (IFV) }\end{array}$ & $\begin{array}{l}\text { http://www.golarlng.com/ } \\
\text { our-fleet/floating-storage- } \\
\underline{\text { and-regasification-units }}\end{array}$ \\
\hline $\begin{array}{l}\text { Nusantara } \\
\text { Regas Satu }\end{array}$ & Operating & 125,000 & 485 & 4.0 & 2012 & $\begin{array}{l}\text { Open } \\
\text { (IFV) }\end{array}$ & $\begin{array}{l}\text { http://www.golarlng.com/ } \\
\text { our-fleet/floating-storage- } \\
\text { and-regasification-units }\end{array}$ \\
\hline Golar Igloo & Operating & 170,000 & 728 & 6.0 & 2014 & $\begin{array}{l}\text { Open } \\
\text { (IFV) }\end{array}$ & $\begin{array}{l}\text { http://www.golarlng.com/ } \\
\text { our-fleet/floating-storage- } \\
\text { and-regasification-units }\end{array}$ \\
\hline
\end{tabular}

${ }^{83}$ These are best estimates based on public domain data but should be confirmed if taken further 

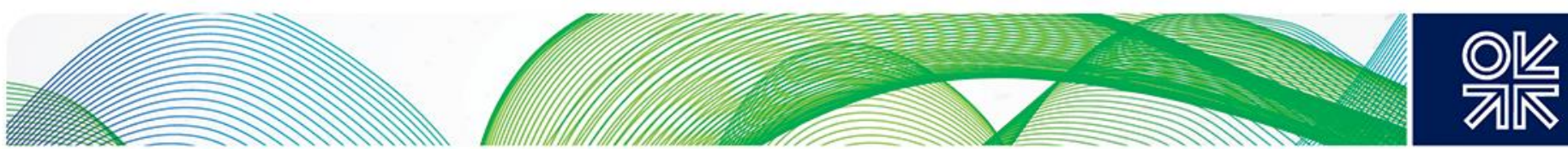

\begin{tabular}{|c|c|c|c|c|c|c|c|}
\hline $\begin{array}{l}\text { Golar } \\
\text { Eskimo }\end{array}$ & Operating & 160,000 & 728 & 6.0 & 2015 & $\begin{array}{l}\text { Open } \\
\text { (IFV) }\end{array}$ & $\begin{array}{l}\text { http://www.golarlng.com/ } \\
\text { our-fleet/floating-storage- } \\
\underline{\text { and-regasification-units }}\end{array}$ \\
\hline $\begin{array}{l}\text { Golar } \\
\text { Tundra }\end{array}$ & Pending & 170,000 & 728 & 6.0 & 2015 & $\begin{array}{l}\text { Open } \\
\text { (IFV) }\end{array}$ & $\begin{array}{l}\text { http://www.golarlng.com/ } \\
\text { our-fleet/floating-storage- } \\
\underline{\text { and-regasification-units }}\end{array}$ \\
\hline \multicolumn{8}{|l|}{ Höegh LNG } \\
\hline Grace & Operating & 170,000 & 500 & 4.1 & 2016 & $\begin{array}{l}\text { Open } \\
\text { (IFV) }\end{array}$ & $\begin{array}{l}\text { http://www.hoeghlng.com } \\
\text { /Pages/Fleet.aspx\#FleetL } \\
\text { istFSRUs-0 }\end{array}$ \\
\hline Gallant & Operating & 170,000 & 500 & 4.1 & 2015 & $\begin{array}{l}\text { Open } \\
\text { (IFV) }\end{array}$ & $\begin{array}{l}\text { http://www.hoeghlng.com } \\
\text { /Pages/Fleet.aspx\#FleetL } \\
\text { istFSRUs-0 }\end{array}$ \\
\hline $\begin{array}{l}\text { Independen } \\
\text { ce }\end{array}$ & Operating & 170,000 & 384 & 3.2 & 2014 & $\begin{array}{l}\text { Open } \\
\text { (IFV) }\end{array}$ & $\begin{array}{l}\text { http://www.hoeghlng.com } \\
\text { /Pages/Fleet.aspx\#FleetL } \\
\text { istFSRUs-0 }\end{array}$ \\
\hline $\begin{array}{l}\text { PGN } \\
\text { Lampung }\end{array}$ & Operating & 170,000 & 360 & 3.0 & 2014 & $\begin{array}{l}\text { Open } \\
\text { (IFV) }\end{array}$ & $\begin{array}{l}\text { http://www.hoeghlng.com } \\
\text { /Pages/Fleet.aspx\#FleetL } \\
\text { istFSRUs-0 } \\
\end{array}$ \\
\hline $\begin{array}{l}\text { GdF Suez } \\
\text { Cape Anne }\end{array}$ & Operating & 145,000 & 750 & 6.2 & 2013 & Closed & $\begin{array}{l}\text { http://www.hoeghlng.com } \\
\text { /Pages/Fleet.aspx\#FleetL } \\
\text { istFSRUs-0 }\end{array}$ \\
\hline $\begin{array}{l}\text { GdF Suez } \\
\text { Neptune }\end{array}$ & Onsite & 145,000 & 750 & 6.2 & 2017 & Closed & $\begin{array}{l}\text { http://www.hoeghlng.com } \\
\text { /Pages/Fleet.aspx\#FleetL } \\
\text { istFSRUs-0 }\end{array}$ \\
\hline Giant & $\begin{array}{c}\text { Pending } \\
\text { assignment }\end{array}$ & 170,000 & 750 & 6.2 & 2017 & $\begin{array}{l}\text { Open } \\
\text { (IFV) }\end{array}$ & $\begin{array}{l}\text { http://www.hoeghlng.com } \\
\text { /Pages/Fleet.aspx\#FleetL } \\
\text { istFSRUs-0 }\end{array}$ \\
\hline \multicolumn{8}{|l|}{ OLT } \\
\hline $\begin{array}{l}\text { FSRU } \\
\text { Toscana }\end{array}$ & Operating & 137,500 & 530 & 4.4 & 2014 & $\begin{array}{l}\text { Open/Trim } \\
\text { Heaters }\end{array}$ & $\begin{array}{l}\text { http://www.oltoffshore.it/e } \\
\text { n/terminal/plant/ }\end{array}$ \\
\hline \multicolumn{8}{|l|}{ MOL } \\
\hline $\begin{array}{l}\text { GNL Del } \\
\text { Plata }\end{array}$ & Delivered & 263,000 & 350 & 3.0 & 2018 & $\begin{array}{l}\text { Open/Trim } \\
\text { Heaters }\end{array}$ & $\begin{array}{l}\text { http://www.offshore- } \\
\text { technology.com/projects/ } \\
\text { gnl-del-plata-project-port- } \\
\text { of-montevideo/ }\end{array}$ \\
\hline \multicolumn{8}{|c|}{ Continued below } \\
\hline \multicolumn{8}{|c|}{ BW Offshore } \\
\hline $\begin{array}{l}\text { BW } \\
\text { Singapore }\end{array}$ & Operating & 170,000 & 750 & 6.2 & 2015 & $\mathrm{n} / \mathrm{a}$ & $\begin{array}{l}\text { http://www.bw- } \\
\text { group.com/our- } \\
\text { business/bw-lng/bw-gas- } \\
\text { solutions }\end{array}$ \\
\hline
\end{tabular}



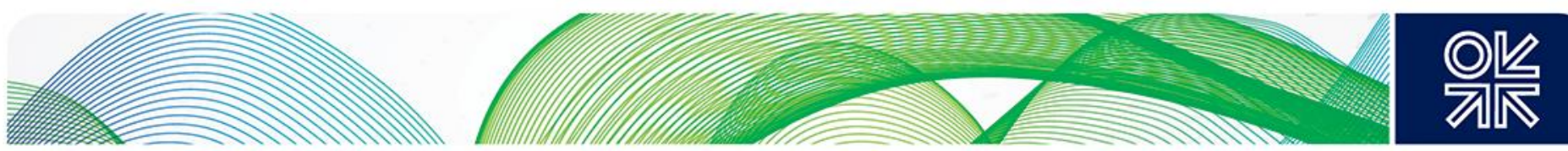

\section{Appendix 2. Current FSU Fleet}

The following table provides summary details of the current FSU fleet in operation or delivered and pending start up and operation. More details and photographs of the vessels can be accessed through the hyperlinks.

\begin{tabular}{|c|c|c|c|c|c|}
\hline Owner & $\begin{array}{l}\text { Vessel } \\
\text { Name }\end{array}$ & Status & $\begin{array}{c}\text { Storage } \\
\mathrm{m}^{3}\end{array}$ & Delivered & Vessel Details \& Photographs \\
\hline $\begin{array}{l}\text { Bumi } \\
\text { Armada }\end{array}$ & $\begin{array}{l}\text { Armada LNG } \\
\text { Mediterrana } \\
\text { (was } \\
\text { Wakaba } \\
\text { Maru) }\end{array}$ & $\begin{array}{l}\text { LNG } \\
\text { Tanker } \\
\text { converted } \\
\text { to FSU } \\
\text { service }\end{array}$ & 125,000 & $\begin{array}{c}\text { Built } 1985 \\
\text { Delivered Malta } \\
2016 \\
17 \text { month } \\
\text { conversion by } \\
\text { Keppel }^{84}\end{array}$ & $\begin{array}{l}\text { http://worldmaritimenews.com/ar } \\
\text { chives/203744/videos-armada- } \\
\text { Ing-mediterrana-enters-maltese- } \\
\underline{\text { waters/ }}\end{array}$ \\
\hline Petronas & Tenaga Satu & $\begin{array}{l}\text { LNG } \\
\text { Tanker } \\
\text { converted } \\
\text { to FSU } \\
\text { service }\end{array}$ & 130,000 & $\begin{array}{c}\text { Built } 1982 \\
\text { Delivered Melaka } \\
2012 \\
\text { Conversion by } \\
\text { MMHE }^{85}\end{array}$ & $\begin{array}{l}\text { http://www.marinetraffic.com/en/ } \\
\text { ais/details/ships/shipid:708106/ } \\
\text { mmsi:533189000/imo:7428457/v } \\
\text { essel:TENAGA SATU }\end{array}$ \\
\hline Petronas & $\begin{array}{c}\text { Tenaga } \\
\text { Empat }\end{array}$ & $\begin{array}{l}\text { LNG } \\
\text { Tanker } \\
\text { converted } \\
\text { to FSU } \\
\text { service } \\
\end{array}$ & 130,000 & $\begin{array}{c}\text { Built } 1981 \\
\text { Delivered Melaka } \\
2012 \\
\text { Conversion by } \\
\text { Keppel } \\
\end{array}$ & $\begin{array}{l}\text { http://www.marinetraffic.com/en/ } \\
\text { ais/details/ships/shipid:708119/ } \\
\text { mmsi:533192000/imo:7428433/v } \\
\text { essel:TENAGA EMPAT }\end{array}$ \\
\hline Golar LNG & Golar Arctic & $\begin{array}{l}\text { LNG } \\
\text { Tanker } \\
\text { converted } \\
\text { to FSU } \\
\text { service }\end{array}$ & 138,000 & $\begin{array}{c}\text { Built } 2003 \\
\text { Delivered Jamaica } \\
2016 \\
\text { Conversion by } \\
\text { Keppel }{ }^{87}\end{array}$ & $\begin{array}{l}\text { http://www.marinetraffic.com/en/ } \\
\text { ais/details/ships/shipid:712073/ } \\
\text { mmsi:538002656/imo:9253105/v } \\
\text { essel:GOLAR ARCTIC }\end{array}$ \\
\hline
\end{tabular}

\footnotetext{
${ }^{84} \mathrm{http}: / /$ www.tradewindsnews.com/weekly/767732/vessel-conversion-for-malta-terminal-proves-complicated

${ }^{85} \mathrm{http}: / /$ www.ship-technology.com/news/news $127884 . \mathrm{html}$

${ }^{86} \mathrm{http}: / /$ www.kepcorp.com/en/news item.aspx?sid=3100

${ }^{87}$ http://gozonews.com/63353/prime-minister-at-the-sail-away-ceremony-of-armada-Ing-mediterrana/
} 

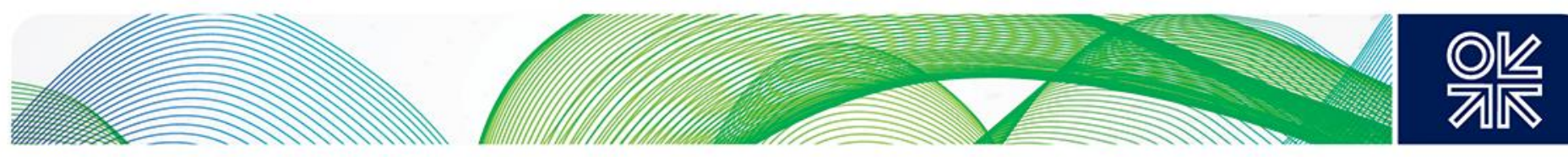

\section{Bibliography}

Challenges and Risk Allocation in FSRU Projects, Holger Kelle, Director INCITIAS, September 2015 FSRUs - A Real Game Changer by Data Fusion Associates, January 2017 https://www.energyinst.org/documents/5092

FSRU Tariffs Paper, Government of Pakistan, QED Consulting, 24 ${ }^{\text {th }}$ July 2013

Implementing an FSRU LNG Import Project, European Gas Conference, Navigant, 19 ${ }^{\text {th }}$ January 2016

LNG Markets in Transition: The Great Reconfiguration, Oxford University Press, 2016, ISBN 978-019-878326-8, https://www.oxfordenergy.org/shop/Ing-markets-in-transition-the-great-reconfiguration/

Time Charter Party \& LNG Storage \& Regasification Agreement by and between Excelerate Energy Puerto Rico, LLC and Puerto Rico Electric Power Authority, March $7^{\text {th }}$, https://www2.aeepr.com/Documentos/Ley57/CONTRATOS\%20GENERAL/2014-0317\%20Time\%20Charter\%20Party\%20and\%20LNG\%20Storage\%20and\%20Regasification\%20Agree ment\%20(wo\%20schedules).pdf

Bangladesh Power Cell, Ministry of Power, Energy and Mineral Resources - Terms of Reference for Technical Advisory for Siting and Basis of design (Feasibility Study) LNG Regasification Terminal.

http://powercell.portal.gov.bd/sites/default/files/files/powercell.portal.gov.bd/page/2008941d d13e 4f3 e a934 615cfcd6f121/TOR\%20for\%20Financial\%20Advisory.pdf 